\title{
Integration of Biorefineries and Nuclear Cogeneration Power Plants - A Preliminary Analysis
}

\section{March 9, 2009}

Prepared by

Sherrell R. Greene George F. Flanagan Abhijeet P. Borole

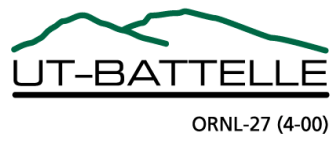




\title{
DOCUMENT AVAILABILITY
}

Reports produced after January 1, 1996, are generally available free via the U.S. Department of Energy (DOE) Information Bridge.

Web site http://www.osti.gov/bridge

Reports produced before January 1, 1996, may be purchased by members of the public from the following source.

\author{
National Technical Information Service \\ 5285 Port Royal Road \\ Springfield, VA 22161 \\ Telephone 703-605-6000 (1-800-553-6847) \\ TDD 703-487-4639 \\ Fax 703-605-6900 \\ E-mail info@ntis.gov \\ Web site http://www.ntis.gov/support/ordernowabout.htm
}

Reports are available to DOE employees, DOE contractors, Energy Technology Data Exchange (ETDE) representatives, and International Nuclear Information System (INIS) representatives from the following source.

Office of Scientific and Technical Information

P.O. Box 62

Oak Ridge, TN 37831

Telephone 865-576-8401

Fax 865-576-5728

E-mail reports@osti.gov

Web site http://www.osti.gov/contact.html

This report was prepared as an account of work sponsored by an agency of the United States Government. Neither the United States Government nor any agency thereof, nor any of their employees, makes any warranty, express or implied, or assumes any legal liability or responsibility for the accuracy, completeness, or usefulness of any information, apparatus, product, or process disclosed, or represents that its use would not infringe privately owned rights. Reference herein to any specific commercial product, process, or service by trade name, trademark, manufacturer, or otherwise, does not necessarily constitute or imply its endorsement, recommendation, or favoring by the United States Government or any agency thereof. The views and opinions of authors expressed herein do not necessarily state or reflect those of the United States Government or any agency thereof. 
ORNL/TM-2008/102

ORNL/GNEP/LTR-2008-047

Nuclear Technology Programs

\section{Integration of Biorefineries and Nuclear Cogeneration Power Plants - A Preliminary Analysis}

Author(s)

Sherrell R. Greene

George F. Flanagan

Abhijeet P. Borole

Date Published: March 9, 2009

Prepared by

OAK RIDGE NATIONAL LABORATORY

Oak Ridge, Tennessee 37831-6283

managed by

UT-BATTELLE, LLC

for the

U.S. DEPARTMENT OF ENERGY

under contract DE-AC05-000R22725 
Blank page 


\section{Table of Contents}

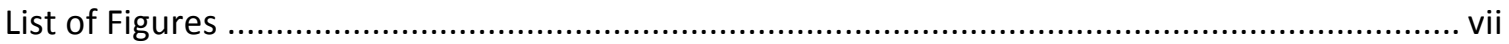

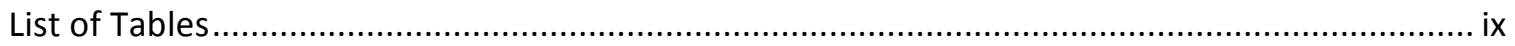

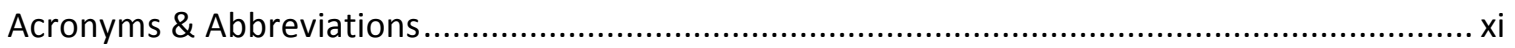

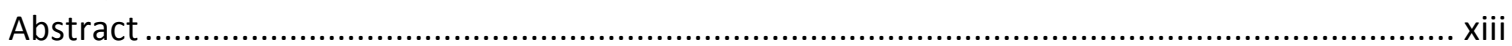

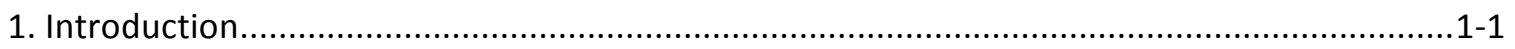

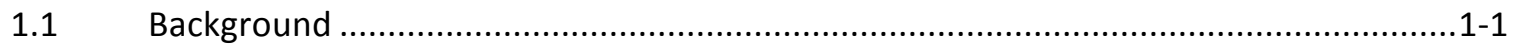

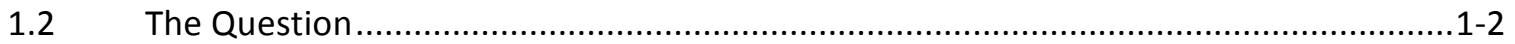

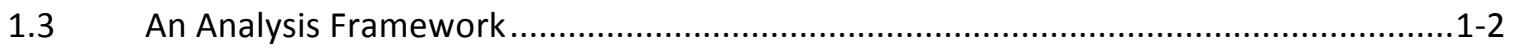

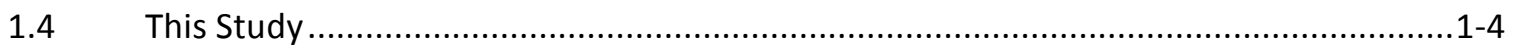

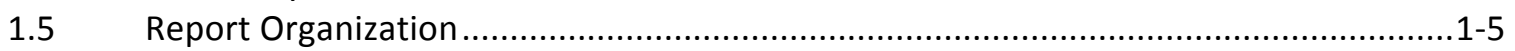

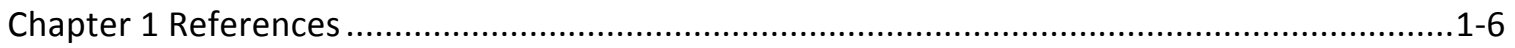

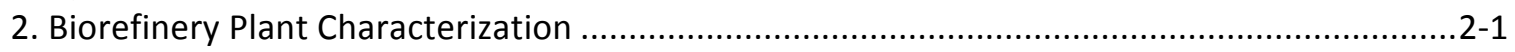

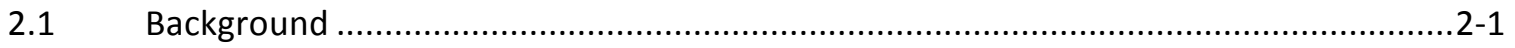

2.1.1 Historical- current program on ethanol production ................................................2-1

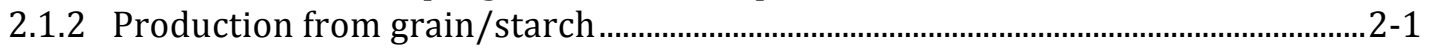

2.1.3 Production from cellulosic materials ............................................................................2-2

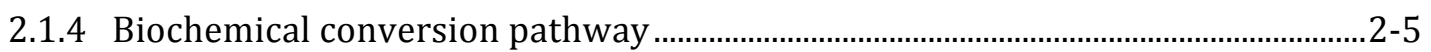

2.1.5 Thermochemical conversion pathway ……..............................................................2-5

2.2 Biochemical Conversion Process \& Facility Description ..............................................2-6

2.2.1 Feedstock input (quantity, form, and storage) ....................................................2-6

2.2.2 Overall layout of the plant (size, interfaces, siting issues) ..........................................2-7

2.2.3 Major components that make up the refinery \& their role during production ..2-8

2.2.4 Energy sources that are currently planned to be used during production ....... 2-11

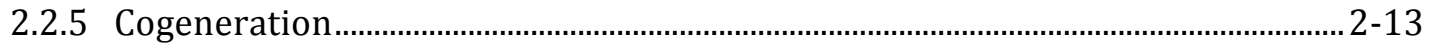

2.2.6 Product output (quantity, form, storage, transportation) ……………………...... 2-13

2.2.7 Waste from process (form, quantity, storage, removal) ............................................ 2-13

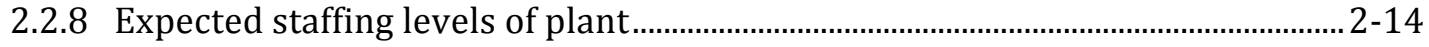

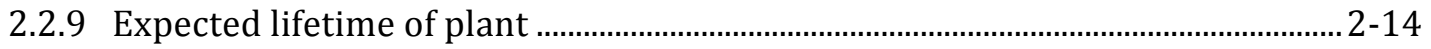

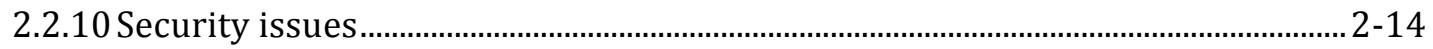

2.2.11 Safety issues .................................................................................................................. 2-14

2.2.12 Economic considerations in ethanol price determination..................................... 2-14

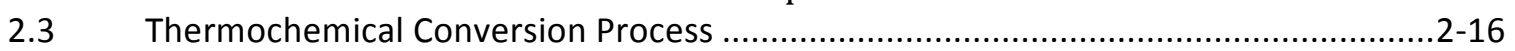

2.3.1 Feedstock input (quantity, form, and storage) ....................................................... 2-16

2.3.2 Overall layout of the plant (size, interfaces, siting issues).................................... 2-16

2.3.3 Major components that make up the refinery \& their role during production 2-18

2.3.4 Simplified process flow diagrams............................................................................ 2-20

2.3.5 Interfaces with other natural resource systems (e.g., water resources) ............ 2-22

2.3.6 Product output (quantity, form, storage, transportation) ....................................... 2-22

2.3.7 Waste from process (form, quantity, hazard level, storage, removal) ................. 2-23

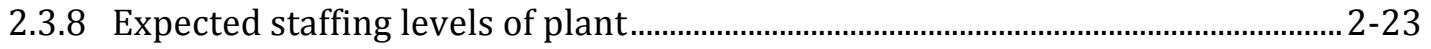

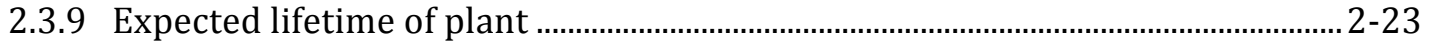

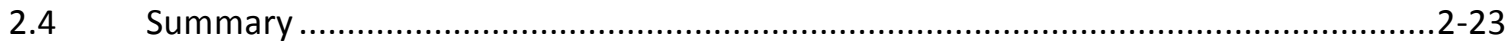

2.4.1 Biochemical refinery characteristics.................................................................. 2-23

2.4.2 Thermochemical refinery characteristics ……….................................................. 2-24

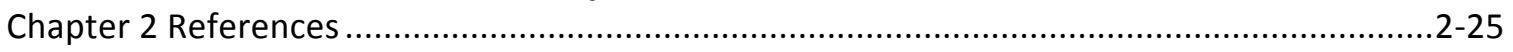

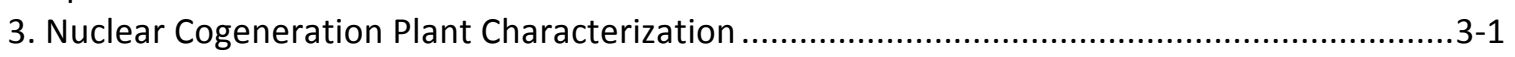

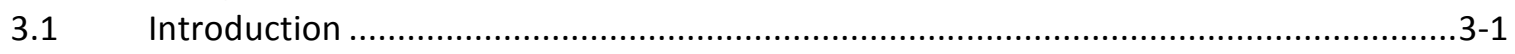

3.2 Nuclear Power Plant Steam Cycles ......................................................................

3.3 Nuclear Plant Characteristics (Based on IRIS) ............................................................ 


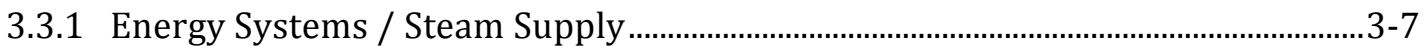

3.3.2 Construction phase of a nuclear power plant............................................................ 3-11

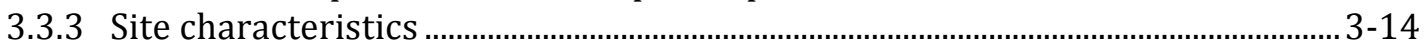

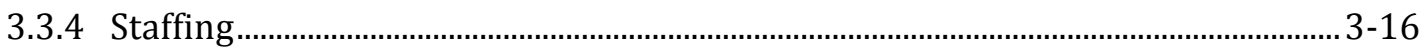

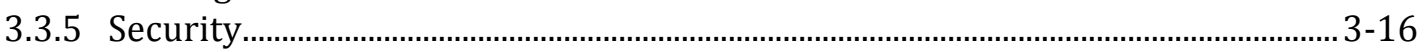

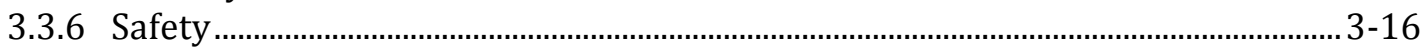

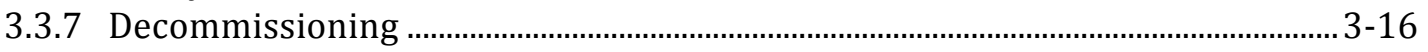

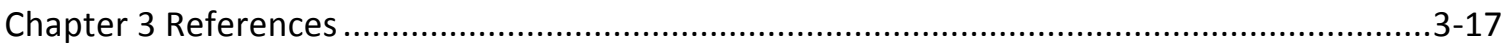

4. Biorefinery and Nuclear Power Plant Integration: Observations and Issues...........................4-1

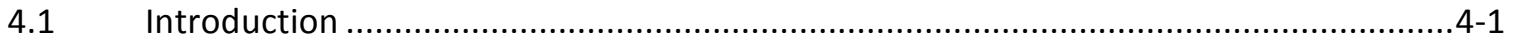

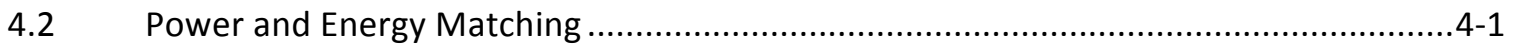

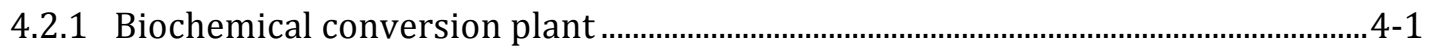

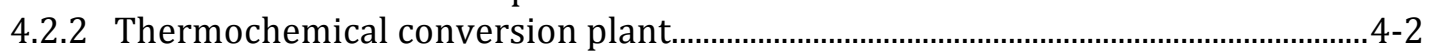

4.2.3 Options for replacing the biorefinery boiler .............................................................. $4-2$

4.2.4 Impacts of eliminating the biorefinery combustor ..................................................

4.2.5 The matter of scale ................................................................................................

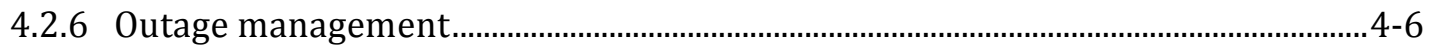

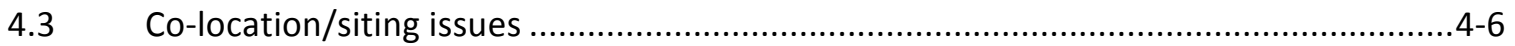

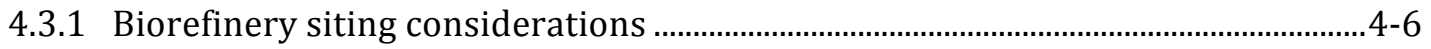

4.3.2 Nuclear power plant siting considerations .................................................................. 4-9

4.3.3 Water requirements ..................................................................................................... 4-10

4.3.4 Material flow management (feedstocks, fuel, wastes, and products) ................. 4-11

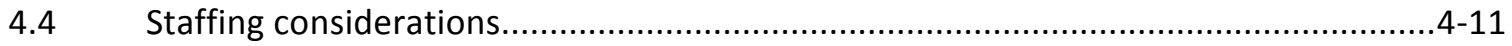

4.5 Construction and Licensing Considerations for Co-located Biorefineries and Nuclear

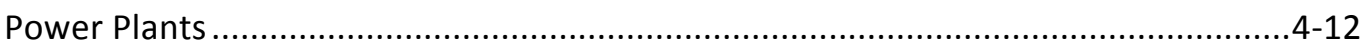

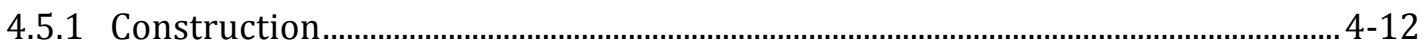

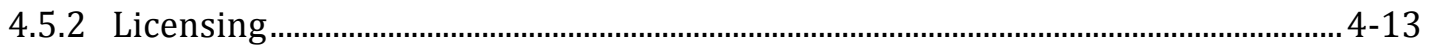

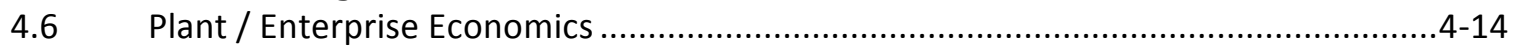

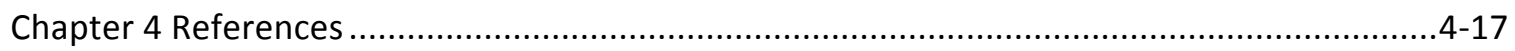

5. Thinking Outside The Box: An Integrated Nuclear - Biomass Energy Enterprise .....................5-1

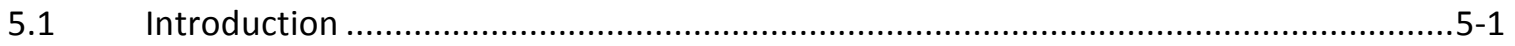

5.2 An Integrated Nuclear - Biofuels Energy Enterprise Model ......................................5-1

5.2.1 Utilizing the Biorefinery Byproducts and Waste Streams .........................................5-2

5.2.2 Intense (Ultra-High-Yield) Biomass Farming ............................................................. 5-3

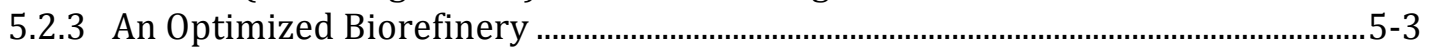

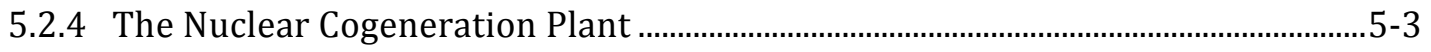

5.2.5 Energy Enterprise Siting Issues............................................................................... $5-3$

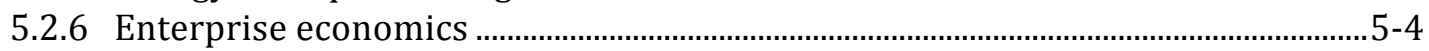

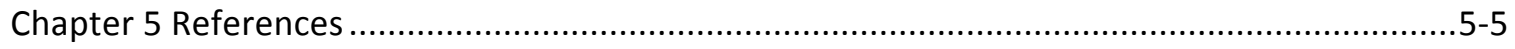

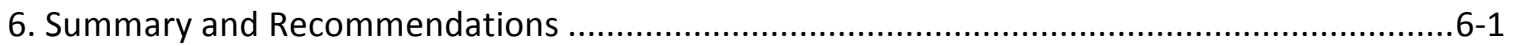

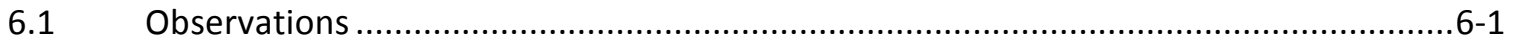

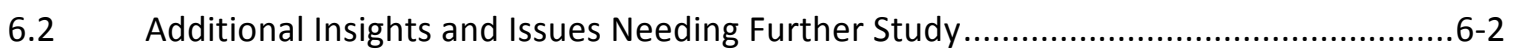

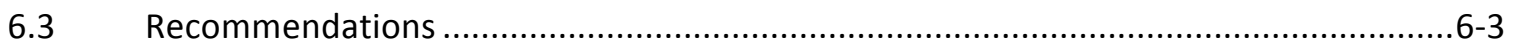

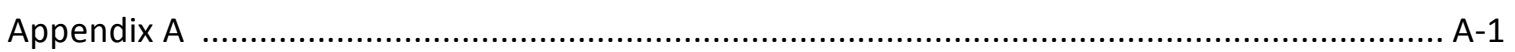

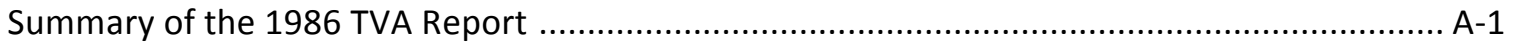

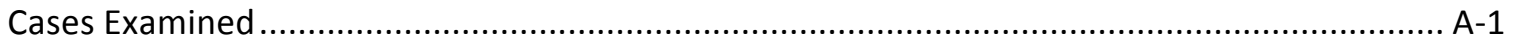

Results

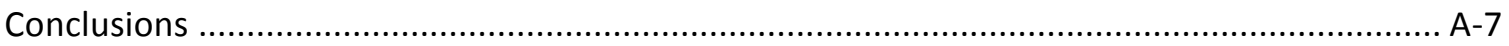

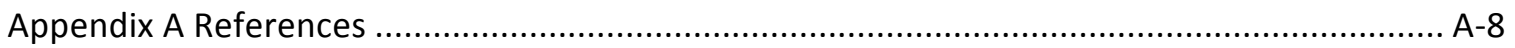




\section{List of Figures}

Figure

1.1 Interfacing concerns between biofuels and nuclear energy production.

2.1 Location of cellulosic biorefineries co-funded by DOE

2.2 Biorefinery siting map for the state of Iowa showing 35,000 MT/d plants, based on feedstock availability and transportation costs.

2.3 Overall Process flow diagram for the biochemical conversion process.

2.4 Circulating fluidized bed combustor/turbogenerator energy balance.

2.5 Ethanol cost as a function of plant size for 10 percent availability of corn acres

2.6 Ethanol price as a function of plant size and hauling cost

2.7 Block flow diagram for thermochemical conversion of biomass feedstocks to ethanol.

2.8 A simplified schematic of the steam and power generator system showing various process streams used to make steam and low-pressure streams extracted from the turbine for use throughout the plant.

3.1 Typical heat balance for a 1000 MWe pressurized water nuclear power plant.

3.2 Low-pressure steam system for a typical 1000MWe pressurized water nuclear power plant.

3.3 Mass flow for the secondary side of a typical 1000 MWe pressurized water
nuclear power plant.

3.4 IRIS Reactor Pressure Vessel

3.5 Steam generator system

3.6 Schematic of the current licensing process for a nuclear reactor

3.7 IRIS reactor pressure vessel showing location of the reactor core and steam generators.

4.1 GIS map of existing and planned nuclear facilities overlaid with estimated ethanol production potential via the biochemical conversion route of agricultural residues and other biomass feedstocks suitable for biochemical conversion.

4.2 GIS map of existing and planned nuclear facilities overlaid with estimated ethanol production potential via the thermochemical conversion of biomass feedstocks.

4.3 Pie charts showing capital, operating and feed material costs for the biochemical, thermochemical and nuclear plants.

5.1 A co-located nuclear-biomass energy enterprise

A.1 Main steam extraction schematic

A.2 High-pressure turbine extraction point schematic

A.3 Cold reheat extraction point schematic
Page

1-3

$2-5$

$2-7$

2-8

$2-13$

2-15

$2-15$

$2-20$

$3-4$

3-5

3-6

3-8

$3-9$

$3-13$

3-15

4-8

4-9

4-15/16

5-2

A-2

A-3

A-4 
Blank page 


\section{List of Tables}

Table

2.1 DOE Pioneer Biorefineries - planned for completion in 2012

Page

2.2 DOE-funded small-scale cellulosic biorefineries approved in 2008

2.3 Characteristics of a biochemical conversion-based ethanol refinery

$2-4$

$2-9$

2.4 Specifications of heat transfer streams in cellulosic ethanol production

$2-12$ plant via the biochemical conversion pathway

2.5 Characteristics of a thermochemical conversion-based ethanol refinery

2.6 Specifications of major heat transfer streams in lignocellulosic ethanol production plant via the thermochemical conversion pathway

3.1 Characteristics of an SMR (based on IRIS design)

4.1 Biorefinery and nuclear power plant (based on IRIS design) power and energy characteristics

4.2 Biorefinery and nuclear power plant site characteristics

4.3 Biorefinery and nuclear power plant civil infrastructure characteristics

4.4 Biorefinery and nuclear power plant construction and licensing characteristics

A.1 Comparison of process heat conditions and efficiency impacts for the three extraction points

A.2 Cost estimate for installation of steam extraction system for use by industry as process heat 
Blank page 


\section{Acronyms \& Abbreviations}

\begin{tabular}{ll} 
4S & Super Safe Small and Simple \\
ACRS & Advisory Committee on Reactor Safeguards \\
CFBC & Circulating fluidized bed combustor \\
CFR & Code of Federal Regulations \\
COL & Combined Operating Licensing \\
D\&D & Design and development \\
DOE & Department of Energy \\
DOE-EERE & Department of Energy Office of Energy Efficiency and Renewable Energy \\
DOE-NE & Department of Energy Office of Nuclear Energy \\
EIS & Environmental Impact Statement \\
ESP & Early site permit \\
GWe & Gigawatt (electric) \\
GIS & Geographic Information System \\
HP & High-pressure \\
IRIS & International Reactor Innovative and Secure \\
kWe & Kilowatt (electric) \\
LLW & Low-level waste \\
LO-CAT & Patented anamine-based process for removal of hydrogen sulfide \\
LP & Low pressure \\
LWR & Light-water reactor \\
MASLWR & Multi-Application Small Light Water Reactor \\
MHTGR & Modular High Temperature Gas Cooled Reactor \\
MM & Million \\
MT & Metric tons \\
MW & Mega Watts \\
MWe & Mega Watts (electric) \\
MWt & Mega Watts (thermal) \\
NGNP & Next Generation Nuclear Plant \\
NHI & Nuclear Hydrogen Initiative \\
NRC & Nuclear Regulatory Commission \\
NREL & National Renewable Energy Laboratory \\
O\&M & Operating and maintenance \\
ORNL & Oak Ridge National Laboratory \\
PBMR & Pebble-bed modular reactor \\
psia & Pounds per square inch (absolute) \\
PWR & Pressurized-water reactor \\
rem & Radiation Equivalent Man \\
SMR & Small/Medium Reactor (<700MWe) \\
VOC & Volatile Organic Compound \\
& \\
\hline
\end{tabular}


Blank page 


\section{Abstract}

Biomass-based ethanol and nuclear power are two viable elements in the path to U.S. energy independence. Numerous studies suggest nuclear power could provide a practical carbon-free heat source alternative for the production of biomass-based ethanol. In order for this coupling to occur, it is necessary to examine the interfacial requirements of both nuclear power plants and bioethanol refineries. This report describes the proposed characteristics of a small cogeneration nuclear power plant, a biochemical process-based cellulosic bioethanol refinery, and a thermochemical process-based cellulosic biorefinery. Systemic and interfacial issues relating to the co-location of either type of bioethanol facility with a nuclear power plant are presented and discussed. Results indicate future co-location efforts will require a new optimized energy strategy focused on overcoming the interfacial challenges identified in the report. 
Blank page 


\section{Introduction}

\subsection{Background}

Biomass-based ethanol and nuclear power are frequently cited as two critical elements in the path to U.S. energy security. ${ }^{1.1}$ Fermentation of biomass and food crops for the production of alcohol dates from ancient times. ${ }^{1.2}$ Ethanol was first described by Lavoisier in 1808.1.3 The first synthetic production of ethanol occurred in 1826, and ethanol has been used as fuel in the United States since 1908. ibid During the last decade, a combination of supply, demand, and other factors have contributed to volatility and the increasing cost of petroleum in the United States and abroad. As discussed later in this report, the U.S. Department of Energy (DOE) and industry are currently collaborating on the development and demonstration of commercial-scale ethanol

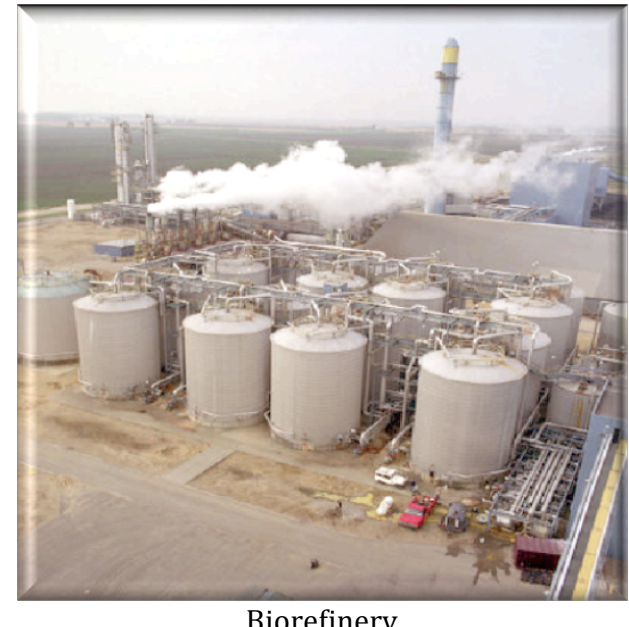

Biorefinery production technologies. Two distinct bioethanol production technologies are being explored: biochemical (fermentation) and thermochemical conversion.

A second artifact of the global energy picture is an emerging demand for a small to medium size reactor (SMR). The SMRs are defined by the International Atomic Energy Agency as having power levels topping out at seven hundred MWe (compared to today's 1+ GWe-class nuclear power plants). They are particularly well suited for developing nations whose electrical grid cannot accommodate the larger plants, or in applications where either the capital cost of the larger plants is prohibitive, or the larger size of established nuclear power plant product lines is otherwise ill suited for the specific application. Dozens of SMR concepts have been proposed in recent years, and a few designs are under active development by industry. ${ }^{1.4}$ Some of these SMR concepts incorporate the capability to produce both electricity and process heat ("cogeneration").

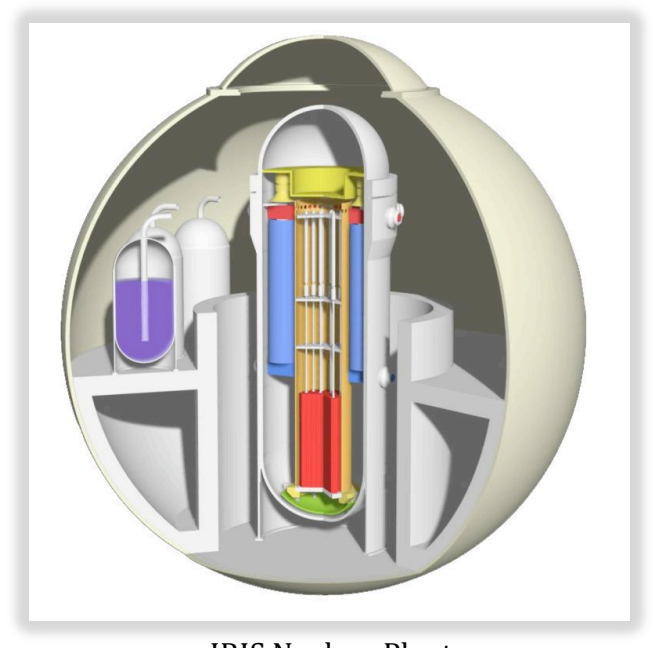

IRIS Nuclear Plant

In addition to the industrial development of SMRs, the DOE is currently pursuing two activities targeting the development and demonstration of nuclear-based process heat. The Next Generation Nuclear Plant (NGNP) program incorporates cogeneration as a major system design requirement. ${ }^{1.5}$ The goal of the Nuclear Hydrogen Initiative (NHI) is to demonstrate the economic, commercial-scale production of hydrogen using nuclear energy. ${ }^{1.6}$ 


\subsection{The Question}

While multiple technologies for biofuels production are under development, one common characteristic of all biofuels production processes is the requirement for energy input (i.e., process heat) at various points in the production process. Currently this process heat is supplied either by combustion of fossil fuels, or some fraction of the process feedstock (25 - 38 percent). If this process heat could be supplied via alternative means, the potential exists to decrease the overall greenhouse gas emission footprint of the biofuels refinery and the net cost of refinery operation while boosting the overall refinery productivity.

The drive to optimize the efficiency and economic competitiveness of emerging biofuels production processes, plus current emphasis on optimizing the design of emerging nuclear power plants for process heat generation, poses the question, "Are there overall benefits to be gained by co-location and interconnection of future biofuels refineries and right-size nuclear cogeneration plants?" In other words, "Is there a marriage of technologies that makes sense?" In April 2008, the DOE's Office of Nuclear Energy (DOE-NE), with the concurrence of DOE's Office of Energy Efficiency and Renewable Energy (DOE-EERE), tasked Oak Ridge National Laboratory (ORNL) with performing a preliminary evaluation of this question.

\subsection{An Analysis Framework}

A thorough examination of the question posed above requires an integrated analysis from several different perspectives (Fig. 1.1), including:

- Process science and technology compatibility;

- Plant / facility operational characteristics compatibility;

- Supporting plant / facility logistics and infrastructure requirements;

- Environmental footprint effects;

- Regulatory framework and regulatory process compatibility;

- Process, facility, and plant economics; and

- Business model options and viability.

The science and technology examination must include more than a simple comparison of bulk biofuels refinery energy demand requirements and the compatibility of secondary steam conditions from existing nuclear power plants. Synthesis and integration of a biofuels refinery and nuclear power plants also raise issues related to the specific forms, qualities, and types of energy demand and supply, energy transport technology options between the nuclear plant and the biofuels plant, etc. In addition, plant size and scaling issues are key considerations. Current and planned biorefinery sizes are based primarily on integrated financial analyses that consider the cost of transporting biomass feedstocks to the refinery, and the cost of refinery operations. 


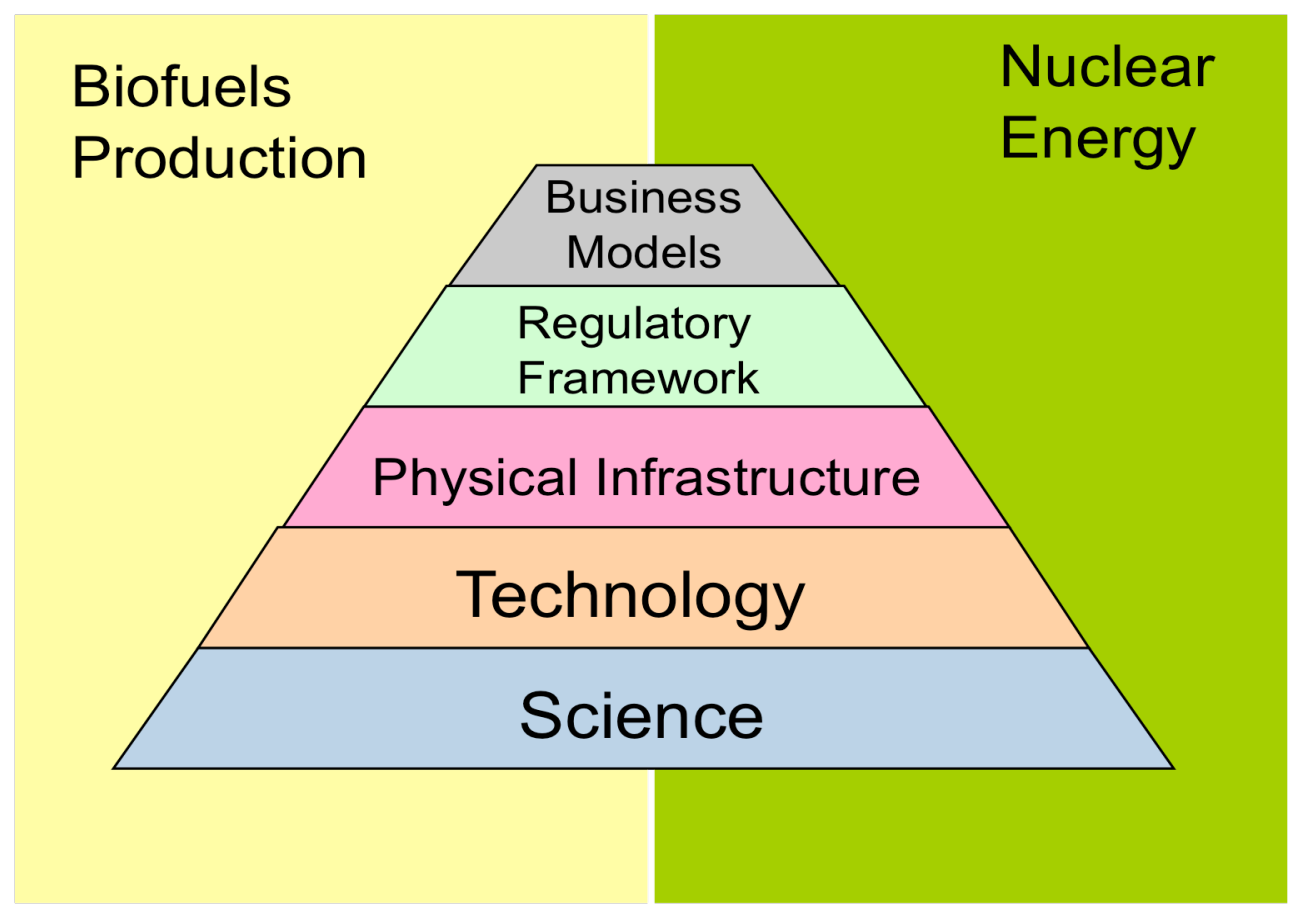

Fig. 1.1. Interfacing concerns between biofuels and nuclear energy production.

Facility and plant operational characteristics must be compatible. This means that both the biofuels plant and the nuclear power plant must be designed to accommodate the other plant's outage frequencies and durations, and other related performance attributes.

The co-location of two facilities will place significant demands on the local civil infrastructure. Industrial complexes such as biorefineries and nuclear power plants require significant civil infrastructure (roads, railways, barge transport capabilities, sizeable skilled staff, etc.) through the entire lifecycle (construction, commissioning, operations, decommissioning) of the plant.

It is important to understand the integrated life-cycle environmental effects of biofuels production with process heat provided by a nuclear power plant compared to conventional biofuels production approaches. Additionally, the potential effect of the combined effluents, waste streams, and waste heat from co-located facilities must be understood in terms of their effect on local air and water quality, watershed thermal limits, etc.

Facility regulation is another uneven issue to consider. Biorefineries are lightly regulated compared to commercial nuclear power plants. The licensing process is simpler, faster, cheaper, and perceived to be less risky than either the traditional U.S. nuclear power plant licensing process or the new Combined Operating License (COL) process recently enacted by the U.S. Nuclear Regulatory Commission (NRC). Interdependencies between the two regulatory processes must be understood, and potential regulatory reform requirements identified to enable a credible analysis of the regulatory and financial risks of forming inter-dependent facilities. 
Both biorefineries and commercial nuclear power plants operate on highly tuned and specialized business models. The economics of bioethanol and nuclear power production are closely tied to plant capital costs, time of construction, cost of money, regulatory processes, and myriad other considerations. The nuclear power plant business model is dominated by the capital cost of the plant. Fuel and operating and maintenance (O\&M) costs are marginal considerations, but these costs have a more significant influence on the economics of biofuels production. The overall "enterprise economics" of a combined biorefinery / nuclear power plant are largely unexplored territory.

\subsection{This Study}

Based upon guidance from DOE-NE and DOE-EERE, the preliminary study documented in this report focused on a plant-level interface analysis of future bioethanol refineries and small nuclear cogeneration power plants. This study is intended to be a preliminary screening analysis. Should the results of the study warrant, more rigorous and comprehensive analyses of the various factors and topics discussed can be conducted to more fully explore the possibilities. Thus, this study focused on plant-level attributes and interfaces. Emphasis was placed on identifying technical and logistics issues associated with plant design and inter-dependent co-located plant operations. Consideration of regulatory and economics/business model implications is left to future analyses.

The study proceeded in the following stages:

First, the relevant descriptive metrics and parameters required to adequately characterize biorefineries (both biochemical and thermochemical) and nuclear cogeneration plants were identified. Near-term biorefinery and nuclear cogeneration plant designs, operating characteristics, and infrastructure requirements were defined in terms of these metrics and parameters.

Then, standalone plant designs and their operating characteristics were examined to identify important interfaces and interdependencies associated with co-located, coupled operation. Design and operational compatibilities, incompatibilities, and unknowns were identified, and specific technology and process issues, and plant design parameters that impact the feasibility and value of plant integration were identified and characterized.

Next, the issues identified in Step 2 were prioritized, a screening for "showstopper" issues was conducted, and a path forward to a more comprehensive and integrated evaluation of a combined biorefinery / nuclear cogeneration plant enterprise was formulated.

This study capitalized on currently available information to characterize the biofuels and nuclear plant options. Heavy reliance was placed on two recently published studies by the National Renewable Energy Laboratory (NREL). 1.7, 1.8 These reports provided detailed plant-level characterizations of modern and near-term biofuels refinery technology and facility options. 


\subsection{Report Organization}

Chapters 2 and 3 document near-term technologies, processes, and plants. Chapter 2 provides a plant-level characterization of industrial-scale biochemical and thermochemical biorefineries. Chapter 3 provides a similar evaluation of current and leading near-term water-cooled, Rankine power conversion cycle nuclear power plants. Chapter 4 discusses design, operations, and infrastructure/logistics issues associated with harmonization of the two technologies. Chapter 5 presents for the first time the concept of a nuclear-bioenergy enterprise as a "park," and identifies some key questions that must be addressed to evaluate the efficacy of the concept. Finally, Chapter 6 provides summary observations and recommendations for a path forward. 


\section{Chapter 1 References}

1.1. Website: http://www.america.gov/st/texttransenglish/2008/March/20080305175150xjsnommis0.5022394.html

1.2. H. Salzberg, From Caveman to Chemist: Circumstances and Achievements, American Chemical Society Publication (1991).

1.3. Website: http://e85.whipnet.net/ethanol.history/

1.4. Overview \& Status of the Global Nuclear Energy Partnership" Presentation at the Advanced Reactors With Innovative Fuels (ARWIF) 2008 meeting, Fukui, Japan

1.5. Website: http://www.ne.doe.gov/pdfFiles/factSheets/NGNP-GENIV-Final-Jan3107.pdf

1.6. Website: http://www.ne.doe.gov/NHI/neNHI.html

1.7. S. Phillips et al., Thermochemical ethanol via indirect gasification and mixed alcohol synthesis of lignocellulosic biomass, NREL/TP-510-41168, National Renewable Energy Laboratory, Golden, CO, April 2007.

1.8. A. Aden, et al., Lignocellulosic biomass to ethanol process design and economics utilizing co-current dilute acid prehydrolysis and enzymatic hydrolysis for corn stover, NREL/TP-510-32438, National Renewable Energy Laboratory, Golden, CO, June 2002. 


\section{Biorefinery Plant Characterization}

\subsection{Background}

\subsubsection{Historical- current program on ethanol production}

The DOE is pursuing a program to support the development of a biomass-based technology for production of ethanol as a transportation fuel. The Energy Independence and Security Act (EISA) targets 368 gallons of ethanol production by 2022. The DOE-EERE's Biomass Program focuses on developing ethanol and other biofuel technologies in partnership with other government agencies, industry and universities. The Biomass Program supports four key priorities of the EERE Strategic Plan:

- $\quad$ Dramatically reduce dependence on foreign oil;

- $\quad$ Promote the use of diverse, domestic and sustainable energy resources;

- $\quad$ Reduce carbon emissions from energy production and consumption; and

- $\quad$ Establish a domestic bioindustry.

Ethanol can be made from grains, such as corn as well as from biomass. The term "biomass" is defined as any plant-derived organic matter available on a renewable basis, including dedicated energy crops and trees, agricultural food and feed crops, agricultural crop wastes and residues, wood wastes and residues, aquatic plants, animal and municipal wastes, and other waste materials. The ethanol produced from biomass is also referred to as cellulosic ethanol, and the biorefineries are referred to as cellulosic or lignocellulosic biorefineries.

\subsubsection{Production from grain/starch}

Ethanol production from corn has been commercialized, and the technology has existed for many years. The initial growth of the bioethanol industry began with ethanol produced from corn and other grains. The main reason for this growth is availability of the technology, and ability of farmers to grow the grains easily. The main target of DOE-EERE's program is development of cellulosic biorefineries rather than grain ethanol because the latter competes with the use of grains as a food source. The corn ethanol industry is expected to reach saturation in the next few years, and very few new plants will be constructed after 2015. The potential timeframe for considering the nuclear-bioenergy synergy is 2015 and later, therefore corn ethanol plants are not considered in this study. 


\subsubsection{Production from cellulosic materials}

Cellulosic ethanol is expected to be a major contributor to the transportation fuels that can reduce our nation's dependence on oil. The United States has the potential to produce over a billion tons of biomass that can be used as raw material for biofuels and bioproducts production.2.1 This resource would in turn produce about 130 billion gallons of ethanol annually (equivalent of 1.9 billion barrels of crude oil).2.2 The current biomass availability is low, but is expected to increase in the future depending on an increase in farming, land availability, improvement in harvesting practices, and improvements in biomass yield and productivity. Current predictions indicate that annual biomass availability may reach 0.29 billion tons per year by 2012. This can result in an estimated 24.2 billion gallons of annual ethanol production by 2012.2.3 It should be noted that this is an estimate of the potential for ethanol production, and that the actual amount of ethanol produced will depend on the readiness of the technology, and the development of requisite infrastructure between now and then. The technologies for cellulosic ethanol production are currently in the commercialization stage. DOE is supporting development of these technologies via partial funding of commercial-size demonstration projects, targeted for completion before 2012. Table 2.1 shows a list of biorefineries that were awarded co-funding from DOE to design, build and demonstrate lignocellulosic feedstocks-based ethanol production. These were termed as 'Pioneer Biorefineries.'

Biomass is made up primarily of three polymers, cellulose, hemicellulose and lignin. Cellulose is a six-carbon sugar polymer, and hemicellulose is a five-carbon sugar polymer. Lignin is a complex polymer made up of phenolic units that acts as a glue, imparting structure to the biomass. Biomass-to-ethanol conversion uses either a biochemical pathway or a thermochemical pathway. Of the six biorefineries announced, two are based on thermochemical conversion technology (Alico, Inc., Range Fuels), three are based on biochemical conversion technology (Bluefire Ethanol, Broin, Iogen), and the sixth is a hybrid of the two technologies (Abengoa Bioenergy). These commercial-scale demonstration projects will provide the basis for future biorefineries. The commercial-scale plants range from 12 to 40 million gallons of ethanol per year. Some of the demonstration plants have initiated construction (2007-08), and have completions scheduled for 2009-11. However, Alico, Inc. recently announced its withdrawal from the proposed project. 
Table 2.1. DOE Pioneer Biorefineries - planned for completion in 2012.

\begin{tabular}{|c|c|c|c|c|c|}
\hline Company & $\begin{array}{l}\text { Location of } \\
\text { biorefinery }\end{array}$ & $\begin{array}{l}\text { Ethanol } \\
\text { production } \\
\text { (M gal/yr) }\end{array}$ & Feedstock type & $\begin{array}{l}\text { Feedstock } \\
\text { (tons/day) }\end{array}$ & $\begin{array}{c}\text { Potential } \\
\text { pathway(s) for } \\
\text { biomass } \\
\text { conversion* }\end{array}$ \\
\hline $\begin{array}{l}\text { Abengoa } \\
\text { Bioenergy } \\
\text { Biomass, } \\
\text { Chesterfield, MO }\end{array}$ & Colwich, KS & 11.4 & $\begin{array}{l}\text { Corn stover, } \\
\text { wheat straw, } \\
\text { milo stubble, } \\
\text { switchgrass, etc. }\end{array}$ & 700 & $\begin{array}{l}\text { Biothermo- } \\
\text { hybrid pathway }\end{array}$ \\
\hline $\begin{array}{l}\text { ALICO, Inc., of } \\
\text { LaBelle, FL** }\end{array}$ & $\begin{array}{l}\text { LaBelle } \\
\text { (Hendry } \\
\text { County), FL }\end{array}$ & $\begin{array}{c}13.9 \\
+6,255 \mathrm{KW} \\
\text { electricity }+ \\
8.8 \text { tons of } \\
\mathrm{H}_{2}+50 \\
\text { tons of } \\
\text { ammonia }\end{array}$ & $\begin{array}{l}\text { Yard waste, } \\
\text { wood and } \\
\text { vegetable waste } \\
\text { (citrus peel) } \\
\text { and eventually } \\
\text { energy cane }\end{array}$ & 770 & $\begin{array}{l}\text { Thermo- } \\
\text { chemical } \\
\text { pathway to syn- } \\
\text { gas, followed by } \\
\text { fermentation }\end{array}$ \\
\hline $\begin{array}{l}\text { BlueFire Ethanol } \\
\text { of Irvine, CA }\end{array}$ & $\begin{array}{l}\text { Southern } \\
\text { California, } \\
\text { located on } \\
\text { landfill }\end{array}$ & 19 & $\begin{array}{l}\text { Green waste, } \\
\text { wood waste } \\
\text { from landfill }\end{array}$ & 700 & $\begin{array}{l}\text { Biochemical } \\
\text { pathway }\end{array}$ \\
\hline $\begin{array}{l}\text { Broin companies } \\
\text { of Sioux Falls, SD }\end{array}$ & $\begin{array}{l}\text { Emmetsburg, } \\
\text { IA (Palo Alto } \\
\text { County) }\end{array}$ & $\begin{array}{l}125(25 \% \\
\text { will be } \\
\text { cellulosic } \\
\text { ethanol) }\end{array}$ & $\begin{array}{l}\text { Corn fiber, cobs, } \\
\text { stalks }\end{array}$ & 842 & $\begin{array}{l}\text { Biochemical } \\
\text { pathway }\end{array}$ \\
\hline $\begin{array}{l}\text { Iogen Biorefinery } \\
\text { Partners of } \\
\text { Arlington, VA }\end{array}$ & $\begin{array}{l}\text { Shelly, ID } \\
\text { (near Idaho } \\
\text { Falls)*** }\end{array}$ & 18 & $\begin{array}{l}\text { Ag waste: } \\
\text { Wheat straw, } \\
\text { barley straw, } \\
\text { corn stover, } \\
\text { switchgrass, } \\
\text { rice straw }\end{array}$ & 700 & $\begin{array}{l}\text { Biochemical } \\
\text { pathway }\end{array}$ \\
\hline $\begin{array}{l}\text { Range Fuels } \\
\text { (formerly Kergy } \\
\text { Inc.) of } \\
\text { Broomfield, CO }\end{array}$ & $\begin{array}{l}\text { Soperton } \\
\text { (Treutlen } \\
\text { County), GA }\end{array}$ & $\begin{array}{c}40 \\
\text { (Ethanol) + } \\
9 \\
\text { (methanol) }\end{array}$ & $\begin{array}{l}\text { Wood residues, } \\
\text { wood based } \\
\text { energy crops }\end{array}$ & 1200 & $\begin{array}{l}\text { Thermo- } \\
\text { chemical } \\
\text { pathway }\end{array}$ \\
\hline
\end{tabular}

Source: http://www.doe.gov/news/4827.htm

*Predicted pathways based on feedstock

**The company announced withdrawal from the proposed project.

***The location to build this plant was recently moved to Canada. 
In addition to the commercial-scale plants, seven other smaller-scale (1-2 million gallons of ethanol/year) cellulosic biorefinery plants have also been awarded cofunding by DOE to initiate construction. These are listed in Table 2.2. As can be seen from Tables 2.1 and 2.2, the biomass feedstock used for ethanol production includes a variety of agricultural residues and waste materials including corn stover, fiber, cobs, straw and stubble from various grain crops, sugarcane bagasse, dedicated biomass crops such as switchgrass, poplar trees, yard wastes, citrus grove waste, landfill waste, hardwoods and softwoods, forest product residues, and paper and pulp industry wastes. In general, agricultural residues and biomass perennial crops are more suitable as a feedstock for biochemical conversion process, and the remaining feedstocks, which are difficult to pretreat, are processed via the thermochemical pathway. Figure 2.1 shows the locations of all the DOE-funded biorefineries in the United States.

Table 2.2. DOE funded small-scale cellulosic biorefineries approved in 2008.

\begin{tabular}{|c|c|c|c|c|c|}
\hline Company & $\begin{array}{l}\text { Location of } \\
\text { biorefinery }\end{array}$ & $\begin{array}{l}\text { Ethanol } \\
\text { production } \\
\text { (M gal/yr) }\end{array}$ & $\begin{array}{c}\text { Feedstock } \\
\text { type }\end{array}$ & $\begin{array}{l}\text { Feedstock } \\
\text { (tons/day) }\end{array}$ & $\begin{array}{l}\text { Potential } \\
\text { pathway(s) for } \\
\text { EtOH conversion }\end{array}$ \\
\hline ICM, Inc. & $\begin{array}{l}\text { St. Joseph, } \\
\text { MO }\end{array}$ & 2.5 & $\begin{array}{l}\text { Agricultural } \\
\text { residues, } \\
\text { such as corn } \\
\text { fiber, corn } \\
\text { stover, } \\
\text { switchgrass } \\
\text { and sorghum }\end{array}$ & 70 & $\begin{array}{l}\text { Integrated } \\
\text { Thermo- } \\
\text { Biochemical } \\
\text { pathway }\end{array}$ \\
\hline $\begin{array}{l}\text { Lognol, } \\
\text { Innovations, Inc. }\end{array}$ & $\begin{array}{l}\text { Commerce } \\
\text { City, CO }\end{array}$ & 2.5 & $\begin{array}{l}\text { Hard and soft } \\
\text { woods }\end{array}$ & 70 & $\begin{array}{l}\text { Biochemical } \\
\text { organisolve }\end{array}$ \\
\hline Stora Enso & $\begin{array}{l}\text { Wisconsin } \\
\text { Rapids, WI }\end{array}$ & 2.5 & Wood wastes & 70 & $\begin{array}{l}\text { Fischer-Tropsch } \\
\text { diesel fuel }\end{array}$ \\
\hline Ecofin, LLC & $\begin{array}{l}\text { Washington } \\
\text { County, KY }\end{array}$ & 1 & Corn cobs & $\mathrm{n} / \mathrm{a}$ & $\begin{array}{l}\text { Biochem/ Ferme } \\
\text { station }\end{array}$ \\
\hline Mascoma* & Vonore, TN & 2 & $\begin{array}{l}\text { Wood chips, } \\
\text { switchgrass }\end{array}$ & $\mathrm{n} / \mathrm{a}$ & $\begin{array}{l}\text { Biochemical / } \\
\text { consolidated } \\
\text { bioprocessing }\end{array}$ \\
\hline $\begin{array}{l}\text { RSE Pulp \& } \\
\text { Chemical, LLC }\end{array}$ & $\begin{array}{l}\text { Old Towne, } \\
\text { ME }\end{array}$ & 2.2 & $\begin{array}{l}\text { Hemicellulose } \\
\text { from wood } \\
\text { pulp }\end{array}$ & $\mathrm{n} / \mathrm{a}$ & $\mathrm{n} / \mathrm{a}$ \\
\hline
\end{tabular}

Sources: http://www.energy.gov/news/5903.htm and

http://www1.eere.energy.gov/biomass/news detail.html?news id=11727

*Mascona recently announced its withdrawal from the proposed project, but DuPont has now joined the project and will build this plant. 


\section{Major DOE Biofuels Project Locations}

Geographic, feedstock and technology diversity

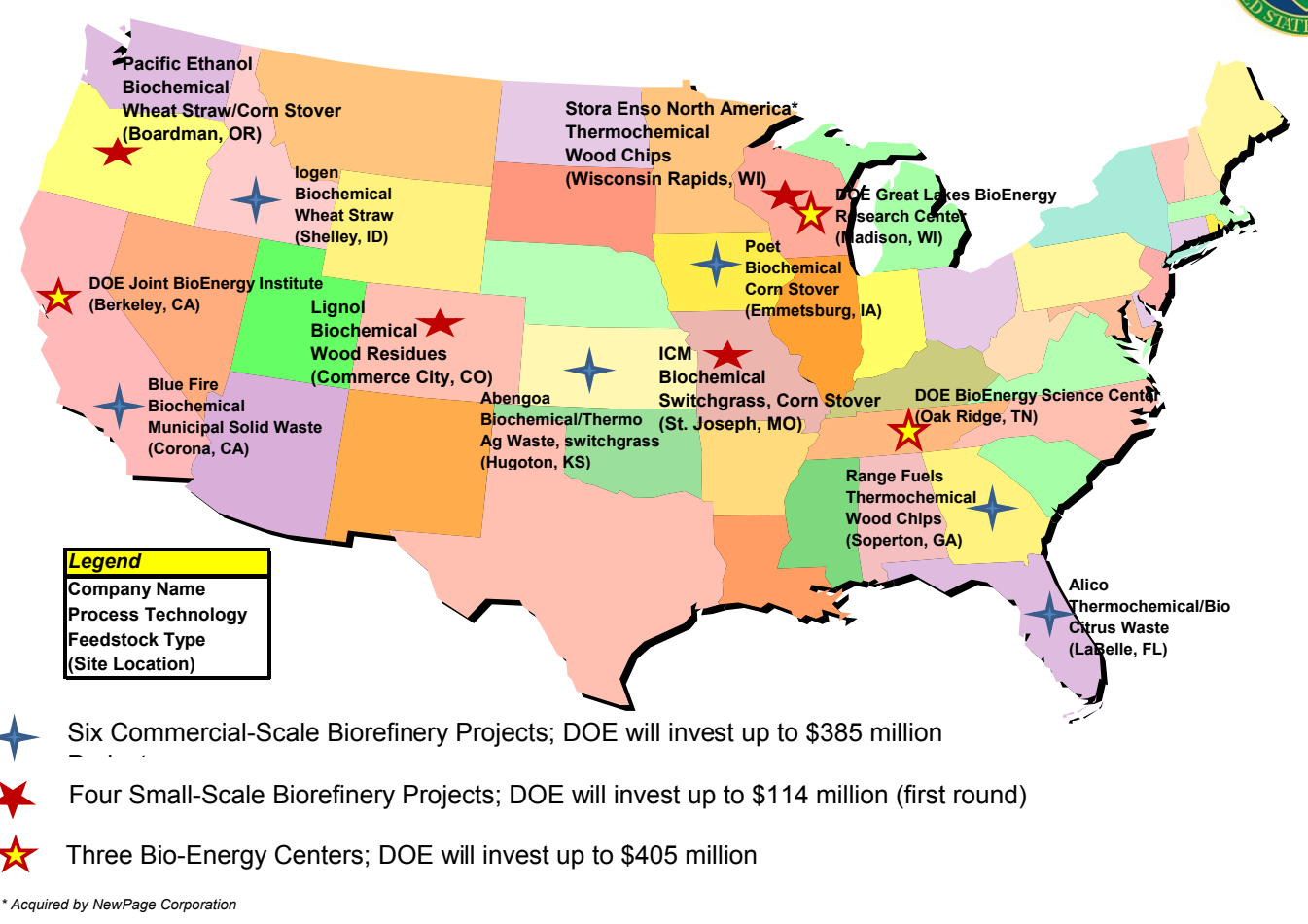

Source: http://www.energy.gov/news/5903.htm

Fig. 2.1. Location of cellulosic biorefineries co-funded by DOE.

\subsubsection{Biochemical conversion pathway}

Conversion of the cellulosic and hemicellulosic polymers present in biomass to ethanol via the biochemical pathway requires multiple steps. The first step is pretreatment, i.e., the breakdown of the structural polymers to enable access to the cellulosic and hemicellulosic components. One common way is to use a dilute acid pretreatment step. This step consists of using heat and dilute acid to treat the biomass, which results in solubilization of the hemicellulose and some of the lignin, and exposure of the cellulose. The next step is enzyme hydrolysis to depolymerize the cellulose to glucose and other sugars. The sugars are then fermented to ethanol using a microbial process.

\subsubsection{Thermochemical conversion pathway}

The thermochemical conversion process consists of partial oxidation of the biomass to synthesis gas (syngas), followed by catalytic conversion of the syngas to ethanol. The syngas is made up of carbon monoxide, hydrogen, water vapor, carbon dioxide, methane and other gases in trace amounts. The process is carried out at elevated temperatures and pressures producing alcohol, followed by separation of the alcohols via distillation. 


\subsection{Biochemical Conversion Process \& Facility Description}

Conversion of corn stover to ethanol via dilute acid pretreatment process was selected as the model biochemical conversion process for assessment of synergy with the nuclear power plant. Corn stover is the most abundant biomass feedstock that is currently available, and will be the major component of feedstocks to be used in the first few biochemical pathway refineries. A comprehensive model and report for this process was available for use in this study (referred to hereafter as the "Biochem report").2.4

\subsubsection{Feedstock input (quantity, form, and storage)}

The biochemical conversion process for ethanol production includes a feedstock interface and a product storage and delivery interface. The feedstock is brought into the plant on tractor-trailers from individual farms, or from a temporary storage facility near the plant. The siting of the plants is essentially controlled by the feedstock availability. Other factors such as water availability, and product delivery options may become important eventually, and are currently under investigation.

The location of a biorefinery using agricultural residues as the primary feedstock depends on the availability and proximity of the feedstock to the biorefinery. A biorefinery siting model called ORIBAS has been developed by ORNL that determines biorefinery locations based on Geographic Information System (GIS) analysis of collection and transportation costs, energy demands, environmental flows, etc. An example of the results from the model are shown in Fig.2.2, derived from the Biochem report. ${ }^{2.4}$ This siting study was based on a plant size capable of handling 2000 metric tons (MT) of corn stover per day. The most important parameter in the siting model is the transportation cost, which can be as high as $\$ 14 / \mathrm{MT}$ for a travel distance of 50 miles. The average cost of hauling bales of corn stover is a function of the radius of the coverage area from the plant location. ${ }^{2.5}$ This cost as well as the overall cost of delivered corn stover is expected to be reduced to below $\$ 33 /$ MT via ongoing research on improving harvesting/collection techniques, baling, storage, etc. Various other factors also determine the feedstock collection radius to meet feedstock supply needs. These include the land covered by farm vs. infrastructure (roads, buildings, etc.), yield of biomass per acre of farmland, sustainability factors affecting amount of biomass harvestable from a given farmland, and coverage of farmland by biomass feedstock vs. other crops (e.g., soybean), etc. Typically, farm coverage of 75 percent is considered appropriate, and a 10 percent availability of farm acres for biomass crops is used (appropriate for the near term). 


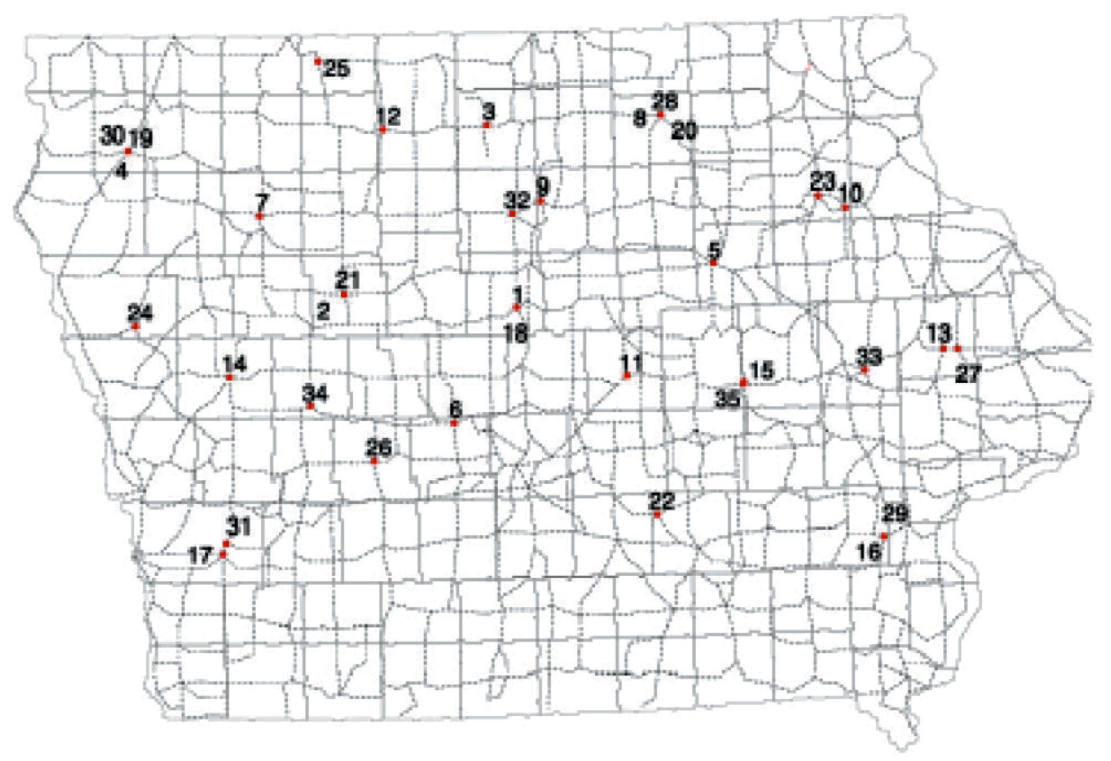

Extracted with permission.

Fig. 2.2. Biorefinery siting map for the state of Iowa showing 35,000 MT/d plants, based on feedstock availability and transportation costs. ${ }^{2.4}$

\subsubsection{Overall layout of the plant (size, interfaces, siting issues)}

The plant consists of seven main areas including feed handling, pretreatment and hydrolysis, saccharification and co-fermentation, product recovery, combustor/boiler/turbogenerator, storage, and wastewater treatment. The overall process flow diagram is shown in Fig.2.3. The process design has been conducted for production of 69 million gallons of ethanol production annually. This requires 2000 tons per day of biomass feedstock, which is corn stover. The details of the plant energy demands and other characteristics are listed in Table 2.3. 


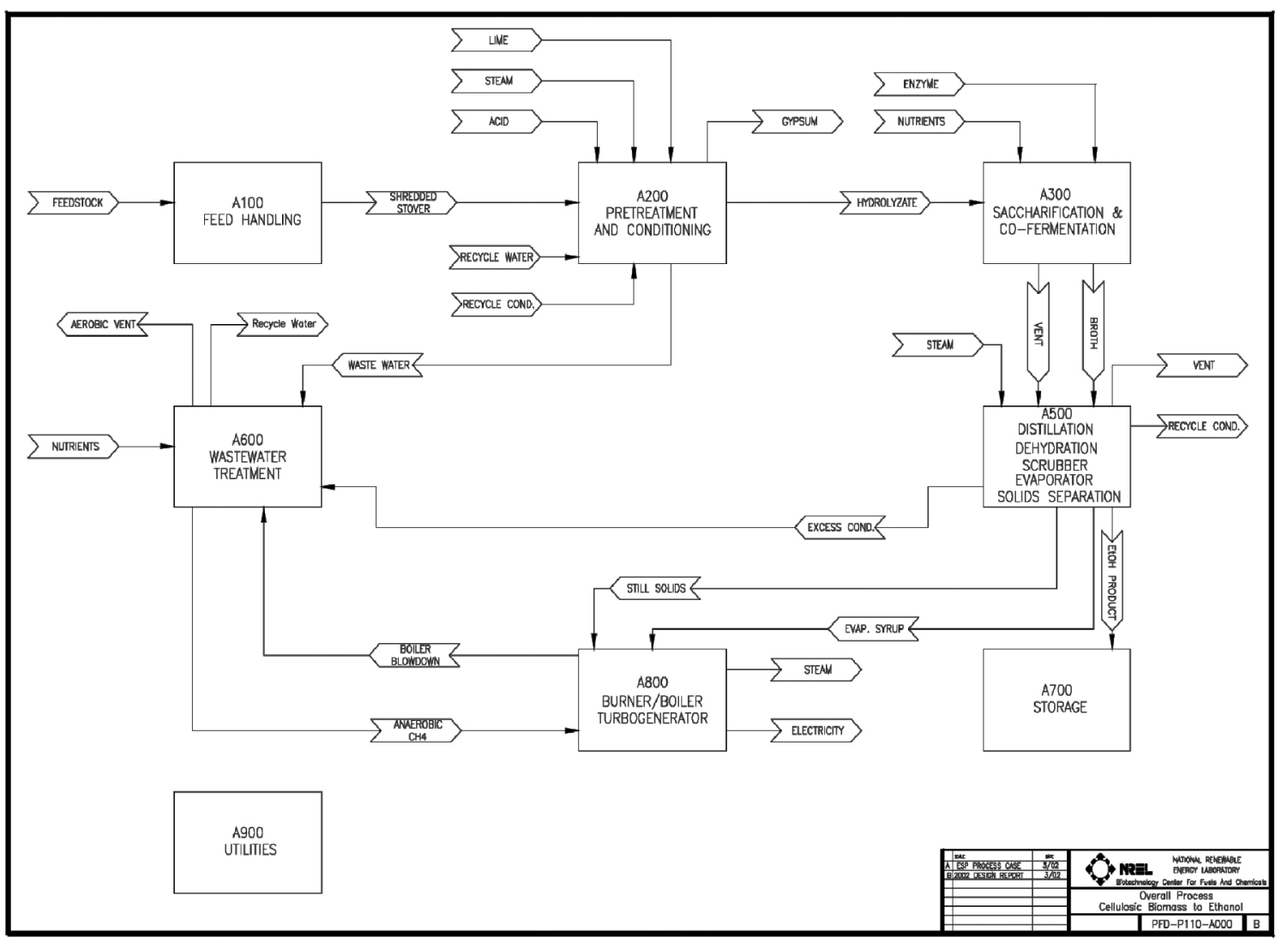

Extracted with permission.

Fig. 2.3. Overall Process flow diagram for the biochemical conversion process. ${ }^{2.4}$

\subsubsection{Major components that make up the refinery and their role during production}

Feed handling. Corn stover bales are delivered to the plant on tractor trailers, unwrapped using an automatic system, washed, passed through a magnetic separator, and sent to the prehydrolysis area for pretreatment. The plant has the capacity to receive 24 tractor-trailer shipments per hour. The water usage is 568 $\mathrm{m}^{3} / \mathrm{hr}$, and the wash water is recycled after passing through a clarifier-thickener. About 4 percent fresh water is required (11,360 gal/hr) as make-up water.

Pretreatment and hydrolyzate conditioning. In the pretreatment process, a hightemperature dilute acid hydrolysis reaction solubilizes most of the hemicellulose to xylose, mannose, arabinose, and galactose. A small portion of the cellulose and glucan in hemicellulose is solubilized into glucose. The lignin polymer is partially solubilized, exposing the cellulose for subsequent treatment. 
Table 2.3. Characteristics of a biochemical conversion-based ethanol refinery.

\begin{tabular}{|c|c|}
\hline Construction Phase & Operations Phase \\
\hline \multicolumn{2}{|c|}{ TIME TO CONSTRUCT } \\
\hline A: Site preparation & 1 month \\
\hline B: Construction & 2.5 years \\
\hline C: Startup testing & 1 month \\
\hline TOTAL & $2.5-3$ years \\
\hline \multicolumn{2}{|c|}{ INFRASTRUCTURE } \\
\hline Rail & $\begin{array}{l}\text { Rail or truck transport for feedstock } \\
\text { transportation required. }\end{array}$ \\
\hline \multicolumn{2}{|c|}{ SITE CHARACTERISTICS } \\
\hline Electric Grid & 20 MWe capacity \\
\hline \multicolumn{2}{|c|}{ WET COOLING TOWER } \\
\hline Water supply & $<1000 \mathrm{gal} / \mathrm{min}$ \\
\hline \multicolumn{2}{|c|}{ SYSTEMS } \\
\hline Power thermal & 103.6 MWt \\
\hline Power electric grid & $18.61 \mathrm{MWe}$ \\
\hline House load & $11.8 \mathrm{MWe}$ \\
\hline \multicolumn{2}{|c|}{ SIIEAM } \\
\hline \multirow{3}{*}{ Process steam needs(mass flow rate in $\mathrm{kg} / \mathrm{sec}$ ) } & $268^{\circ} \mathrm{C}, 191$ psia $(10.3)$ \\
\hline & $164^{\circ} \mathrm{C}, 65$ psia (18.3) \\
\hline & $115^{\circ} \mathrm{C}, 25$ psia $(1.4)$ \\
\hline \multicolumn{2}{|c|}{ OPERATIONS } \\
\hline Availability date & $>2012$ \\
\hline Plant availability & $96 \%$ \\
\hline Plant life & 20 years \\
\hline \multicolumn{2}{|c|}{ STAFFING } \\
\hline Operations & $\sim 60$ personnel \\
\hline
\end{tabular}

In this process, the biomass is heated in a presteamer to $100^{\circ} \mathrm{C}$ for 20 minutes using low-pressure steam. The preheated biomass is fed into an acid pretreatment reactor that is operated at $190^{\circ} \mathrm{C}$ and $12.1 \mathrm{~atm}$ using superheated steam, with a residence time of 2 minutes..

Byproducts from this treatment include acetic acid, furfural, hydroxymethyl furfural, and phenolic monomers, which are inhibitors to the fermentation process. A step including flash cooling and lime conditioning is used to remove these molecules to the extent possible. The vapor released during flash cooling $\left(100^{\circ} \mathrm{C}, 53,000 \mathrm{~kg} / \mathrm{hr}\right)$ is used to preheat the distillation column. A solid-liquid separation step is included prior to overliming to separate solids containing cellulose and again after $\mathrm{pH}$ adjustment to remove precipitated gypsum. 
Saccharification and co-fermentation. Cellulose converts to glucose using cellulase enzymes, and the sugars ferment to ethanol using microbial catalysts. The saccharification occurs optimally above $60^{\circ} \mathrm{C}$, while the fermentation requires a temperature below $45^{\circ} \mathrm{C}$. Thus, the process is carried out by performing partial saccharification at $65^{\circ} \mathrm{C}$, followed by continued saccharification and fermentation at $41^{\circ} \mathrm{C}$. A heat exchanger $(\mathrm{H}-301)$ heats the hydrolyzate slurry to $65^{\circ} \mathrm{C}$ using lowpressure steam. Saccharification is conducted in a train of five vessels $(950,000$ gal/ea) at the higher temperature, followed by fermentation in a train of five vessels of similar size.

Products, water and solids recovery. Ethanol separation from the fermentation stream is achieved via distillation and molecular sieve adsorption. Distillation occurs in two columns: the first is called a beer column, where dissolved carbon dioxide is removed from the top, and most of the water is separated in the bottoms. The ethanol is removed as a vapor side draw ( $~ 99$ percent of the feed) from the column as a 39 percent mixture with water. This column requires steam for heating the bottoms (stream $\mathrm{H} 501,164^{\circ} \mathrm{C}$ and $4.42 \mathrm{~atm}, 33.76 \mathrm{MM} \mathrm{kcal} / \mathrm{hr}$ ). The second rectification column then concentrates the ethanol stream to an azeotropic mixture. Ethanol is purified from the azeotropic mixture using vapor-phase molecular sieve adsorption.

The bottom contents of the distillation columns are dewatered and used as fuel in combustor. About 25 percent of the liquid filtrate is directly recycled. The remaining filtrate, which has dissolved organic carbon, is concentrated in a series of evaporators and then sent to combustor. The evaporated water is then condensed and recycled.

The first evaporator is heated using two sources: the reflux vapor from the rectification column and low-pressure steam (1.7 atm, 25 psia). The second and third evaporators are heated using vapor from first and second evaporators, respectively.

Combustor, boiler, and turbogenerator. The purpose of this unit is to burn various by-product streams for steam and electricity production. The lignin and residual cellulose and hemicellulose form the main fuel component. The concentrated syrup from the evaporators, biogas from anaerobic digestor, sludge solids from the aerobic digestor make up the other components. This unit makes the overall process self-sufficient in energy and produces extra electricity to be sold to the grid. The mixture is burned in a circulating fluidized bed combustor (CFBC), converting water into superheated steam $\left(510^{\circ} \mathrm{C}\right.$ and $\left.86 \mathrm{~atm}\right)$ at a rate of $184,771 \mathrm{~kg} / \mathrm{hr}$. The boiler efficiency is 68 percent. Flue gas exiting the combustor preheats the in-coming air, and is released after particulate capture in a bag house.

A multistage turbine and a generator are used to generate electricity. Steam is extracted from the turbine at three different conditions for injection into the pretreatment reactor, heat exchanger in distillation column, and the evaporator. Twenty-eight (28) percent of the steam is extracted from the turbine at 13 atm (191 
psia, $\left.268^{\circ} \mathrm{C}\right), 60$ percent at $4.4 \mathrm{~atm}\left(65 \mathrm{psia}, 164^{\circ} \mathrm{C}\right)$ and 3 percent at $1.7 \mathrm{~atm}(25$ psia, $115^{\circ} \mathrm{C}$ ).

Wastewater treatment. The plant wastewater consisting of condensed pretreatment flash vapor, condensate from the hydrolyzate filter vent, boiler blowdown, cooling tower blowdown, clean-in-place waste, and non-recycled evaporator condensate are treated using a particle screen, followed by an anaerobic and an aerobic digestor. Biogas is produced in the anaerobic digestor, which is used in the combustor. The aerobic digestor produces a sludge that is also burned in the combustor and a relatively clean water stream, which is recycled.

Feed and product storage. Feed chemical stored on site includes corn steep liquor (nutrient source for fermentation seed growth), sulfuric acid (for acid treatment), enzyme propane (for forklifts), and gasoline (for denaturing ethanol). A 4-5 day stock of feed chemicals is generally maintained. The corn steep liquor and other nutrients are most likely supplied by rail cars. The propane is stored in $13 \mathrm{~m}^{3}$ tank ( 3435 gal) at 250 psig to supply 15 days of fuel for the forklifts. Gasoline is stored in a $241 \mathrm{~m}^{3}$ tank used at 5 percent concentration in the product (7-day supply). Ethanol product storage is designed to correspond for 7 days of production (4540 $\mathrm{m}^{3}, 1.2$ million gallons) in two tanks. A firewater pump is sized for $568 \mathrm{~m}^{3} / \mathrm{hr}(2,500$ $\mathrm{gal} / \mathrm{min})$.

$\underline{\text { Utilities. }}$ The process water uses recycle water mixed with make-up water, and provides water at constant pressure. Water is provided to the stover washer system, seed production, boiler feed water, cooling tower make-up, the clean-in-place system, and the scrubber. The process is designed for zero discharge to a municipal wastewater treatment plant in a steady-state mode. The make-up water (well water) accounts for water losses to atmosphere due to evaporation, water in streams vented to the atmosphere, water entrained in waste solids, water for hydrolysis of sugar polymers, and the digestion processes. The total well water required to make up lost water is $186,600 \mathrm{~kg} / \mathrm{hr}(50,000 \mathrm{gal} / \mathrm{hr})$.

\subsubsection{Energy sources that are currently planned to be used during production}

Heat is required for various unit operations in the biochemical process for ethanol production. The unit operations include pretreatment and conditioning, distillation and dehydration, evaporation and wastewater treatment. A total of $89.08 \mathrm{MM}$ $\mathrm{kcal} / \mathrm{hr}$ of heat or 103.6 MWt is required, which is supplied via low-pressure steam. Three different steam conditions are needed. One at $268^{\circ} \mathrm{C}$ and $13 \mathrm{~atm}$, a second stream at $164^{\circ} \mathrm{C}$ and $4.42 \mathrm{~atm}$ and a third at $115^{\circ} \mathrm{C}$ and 1.7 atm (Table 2.4). 
Table 2.4. Specifications of heat transfer streams in cellulosic ethanol production plant via the biochemical conversion pathway. Definitions for each unit operation were extracted from the Biochem report. ${ }^{2.4}$

\begin{tabular}{|c|c|c|}
\hline Unit Operation & $\begin{array}{l}\text { Thermal Energy } \\
\text { Required }\end{array}$ & Steam Specifications \\
\hline Prehydrolysis reactor & $0.699 \mathrm{MW}$ & $\begin{array}{l}268^{\circ} \mathrm{C}, 13 \mathrm{~atm} \text { to } 190^{\circ} \mathrm{C} \text { and } \\
12.05 \mathrm{~atm}(37,234 \mathrm{~kg} / \mathrm{hr})\end{array}$ \\
\hline Beer column feed economizer & $\begin{array}{l}-0.22 \mathrm{MW} \\
-25.95 \mathrm{MW}\end{array}$ & $\begin{array}{l}190^{\circ} \mathrm{C} \text { and } 12.05 \mathrm{~atm} \text { to } 101^{\circ} \mathrm{C} \text {, } \\
1 \mathrm{~atm} \text {. }\end{array}$ \\
\hline $\begin{array}{l}\text { Saccharification and co-fermentation (LP } \\
\text { steam to heat detoxified hydrolyzate) }\end{array}$ & $-5.69 \mathrm{MW}$ & $\begin{array}{l}164^{\circ} \mathrm{C}, 4.42 \mathrm{~atm} \text { to } 148^{\circ} \mathrm{C}, 4.42 \\
\mathrm{~atm}, 9490 \mathrm{~kg} / \mathrm{hr}\end{array}$ \\
\hline Seed fermentor heater coils & $11.4 \mathrm{~kW}$ & Hot water at $\mathrm{T}=41^{\circ} \mathrm{C}, \mathrm{P}=1 \mathrm{~atm}$ \\
\hline Seed fermentor heater coils & $39 \mathrm{~kW}$ & Hot water at $\mathrm{T}=41^{\circ} \mathrm{C}, \mathrm{P}=1 \mathrm{~atm}$ \\
\hline Distillation (beer column reboiler) & $\begin{array}{l}0.43 \mathrm{MW} \\
-39.26 \mathrm{MW}\end{array}$ & $\begin{array}{l}164^{\circ} \mathrm{C}, 4.42 \mathrm{~atm} \text { to } 148^{\circ} \mathrm{C}, 4.42 \\
\mathrm{~atm}, 65505 \mathrm{~kg} / \mathrm{hr} .\end{array}$ \\
\hline Distillation (second rectification column) & $-4.90 \mathrm{MW}$ & $\begin{array}{l}164^{\circ} \mathrm{C}, 4.42 \mathrm{~atm} \text { to } 148^{\circ} \mathrm{C}, 4.42 \\
\mathrm{~atm}, 8164 \mathrm{~kg} / \mathrm{hr}\end{array}$ \\
\hline $\begin{array}{l}\text { Distillation (rectification column vapor } \\
\text { heater) }\end{array}$ & $-0.37 \mathrm{MW}$ & $\begin{array}{l}164^{\circ} \mathrm{C}, 4.42 \mathrm{~atm} \text { to } 148^{\circ} \mathrm{C}, 4.42 \\
\mathrm{~atm}, 621 \mathrm{~kg} / \mathrm{hr}\end{array}$ \\
\hline $\begin{array}{l}\text { Burner/boiler/turbogenerator (steam from } \\
\text { lignin boiler) (A802) }\end{array}$ & $2.90 \mathrm{MW}$ & $\begin{array}{l}115^{\circ} \mathrm{C}, 1.68 \mathrm{~atm} 97 \% \text { vapor to } \\
115^{\circ} \mathrm{C}, 1.68 \mathrm{~atm}, 0 \% \text { vapor, } \\
4858 \mathrm{~kg} / \mathrm{hr}\end{array}$ \\
\hline $\begin{array}{l}\text { Air preheater for lignin burner (This is } \\
\text { heated using flue gas from lignin burner). } \\
\text { This may not be required if no lignin is } \\
\text { burned. }\end{array}$ & $13.79 \mathrm{MW}$ & \\
\hline
\end{tabular}

The amount of electricity needed by the plant is 11.86 MWe. This electricity is produced from burning lignin and other waste products as discussed in the section on cogeneration below. In addition, 18.61 MWe of power is generated that is sold to the grid. 


\subsubsection{Cogeneration}

The biochemical refineries derive a significant portion of the energy required for plant operation from cogeneration. The various biomass waste streams including lignin, unconverted cellulose and hemicellulose remaining from the biomass conversion process, concentrated syrup produced from wastewater processing, as well as waste sludge from an aerobic digestion process are collected and used as fuel in a CFBC/boiler to produce high pressure steam. In addition, biogas produced from the anaerobic digestion is also used as a fuel for cogeneration. The highpressure steam produced in the boiler is used in a turbogenerator to produce electricity, bleeding a side stream of low-pressure steam to be used for heating purposes.

Elimination of the combustor/boiler-turbogenerator will result in generation of waste streams from the anaerobic and aerobic digestor, evaporator solids, and the biogas. The lignin constitutes about 59 percent of the fuel to the boiler, with the remaining consistency the waste streams and the biogas (See Fig. 2.4).

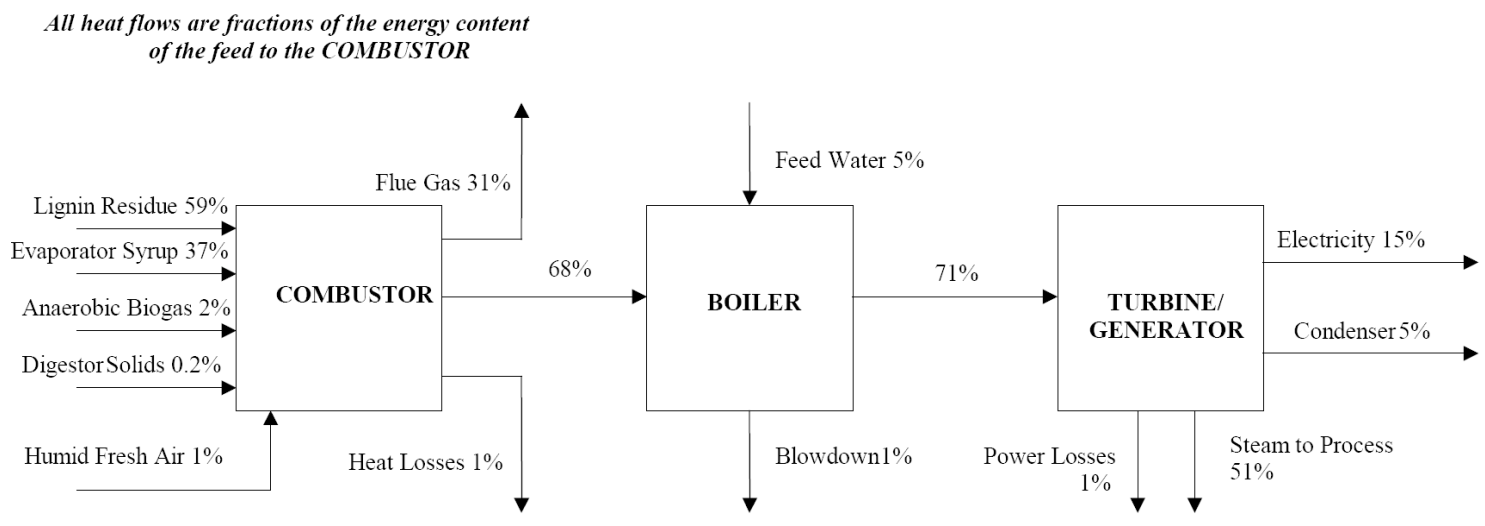

Extracted with permission.

Fig. 2.4. Circulating fluidized bed combustor / turbogenerator energy balance.2.4

\subsubsection{Product output (quantity, form, storage, transportation)}

The ethanol product from the plant is 99.5 percent pure, with the balance made up of water. It is stored in two 600,000 gal carbon steel tanks (7-days of production) before being transported via rail or trucks.

\subsubsection{Waste from process (form, quantity, storage, removal)}

The process generates minimal waste because most solids and water are recycled. The screening process used in wastewater treatment plant produces solid waste consisting of large particles, which are sent to a landfill. The effluent gases are scrubbed to capture any ethanol, resulting in removal of 99.5 percent ethanol from 
the vents. The maximum amount of ethanol allowed to be emitted into the atmosphere is $36.3 \mathrm{MT}$ as a volatile organic compound (VOC), based on air pollution considerations.

\subsubsection{Expected staffing levels of plant}

The plant will employ personnel for management (5), plant shift supervisors (5), technicians (10), operators (20), yard laborers (32), and secretaries (5).

\subsubsection{Expected lifetime of plant}

The expected operational lifetime of the plant is twenty years.

\subsubsection{Security issues}

Security issues at the plant are minimal. At the most, four guards will be employed to man the entrance gates to the plant.

\subsubsection{Safety issues}

The biochemical plant requires handling of concentrated acids (for pretreatment), alkali (for $\mathrm{pH}$ adjustment), and large quantities of ethanol. Secondary containment for hazardous chemicals is included in equipment design. Safety issues regarding storage of ethanol produced in the plant exist, but are not a significant concern since the plant only stores only a 5-day production capacity of ethanol.

\subsubsection{Economic considerations in ethanol price determination}

The cost of ethanol production in a biorefinery is a function of the feedstock cost, and the process cost for conversion of biomass to ethanol. Both of these factors impact the size of the plant. The size of the plant typically increases with the process cost; however, the reverse relationship holds true for the feedstock cost. The feedstock cost and the transportation cost thus limit the overall plant size. Fig. 2.5 shows a plot of minimum ethanol price vs. plant size, and splits the total cost into feedstock vs. other costs. The ethanol price is the same over the range of 2,000 to 10,000 MT of corn stover for the cost assumed for the feedstock. An increase in the transportation costs, however, can offset this as shown in Fig. 2.6. The plot shows the effect of 1.5- to two-fold increase in transportation costs on the price of ethanol. A two-fold increase in the transportation cost reduces the range of feedstock to 2,000 - 3,000 MT/day. 


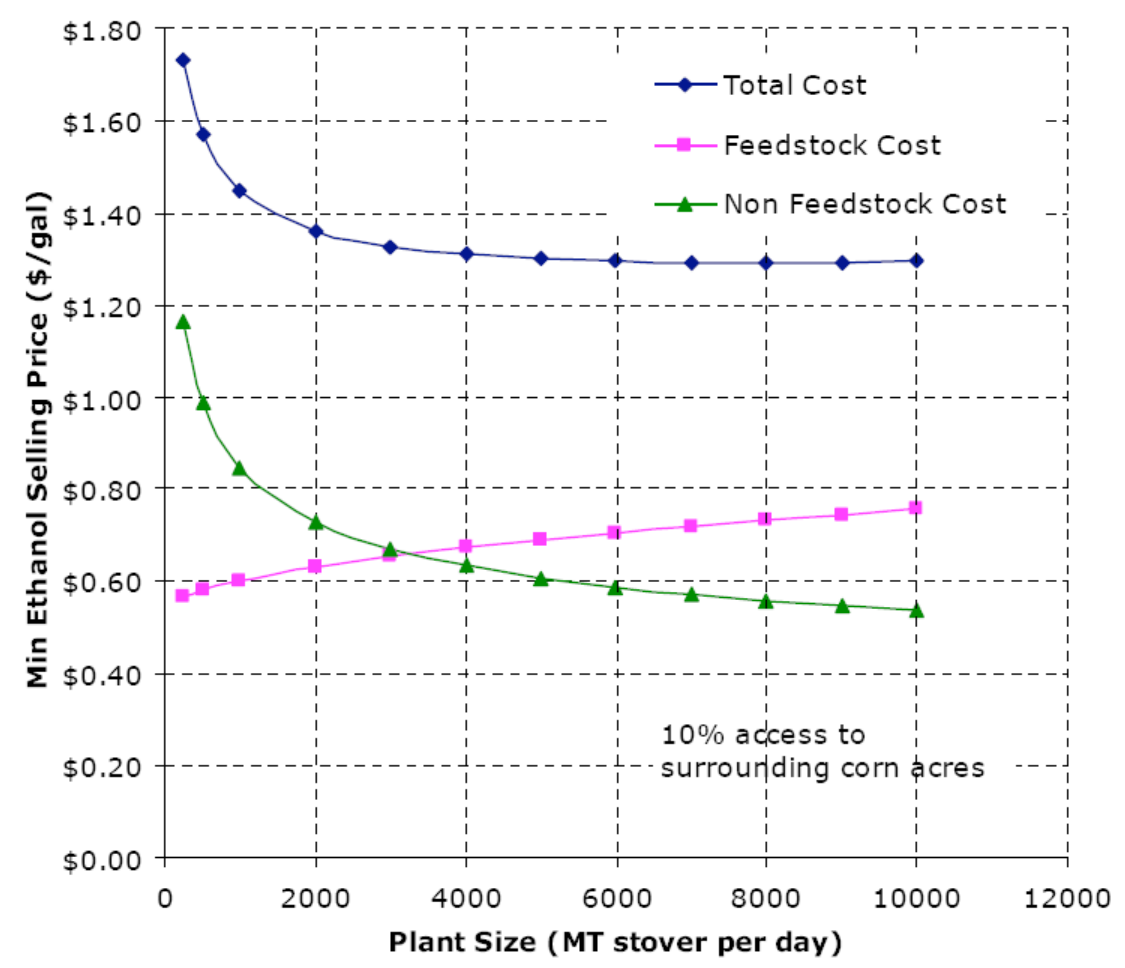

Extracted with permission.

Fig. 2.5. Ethanol cost as a function of plant size for 10 percent availability of corn acres. 2.4

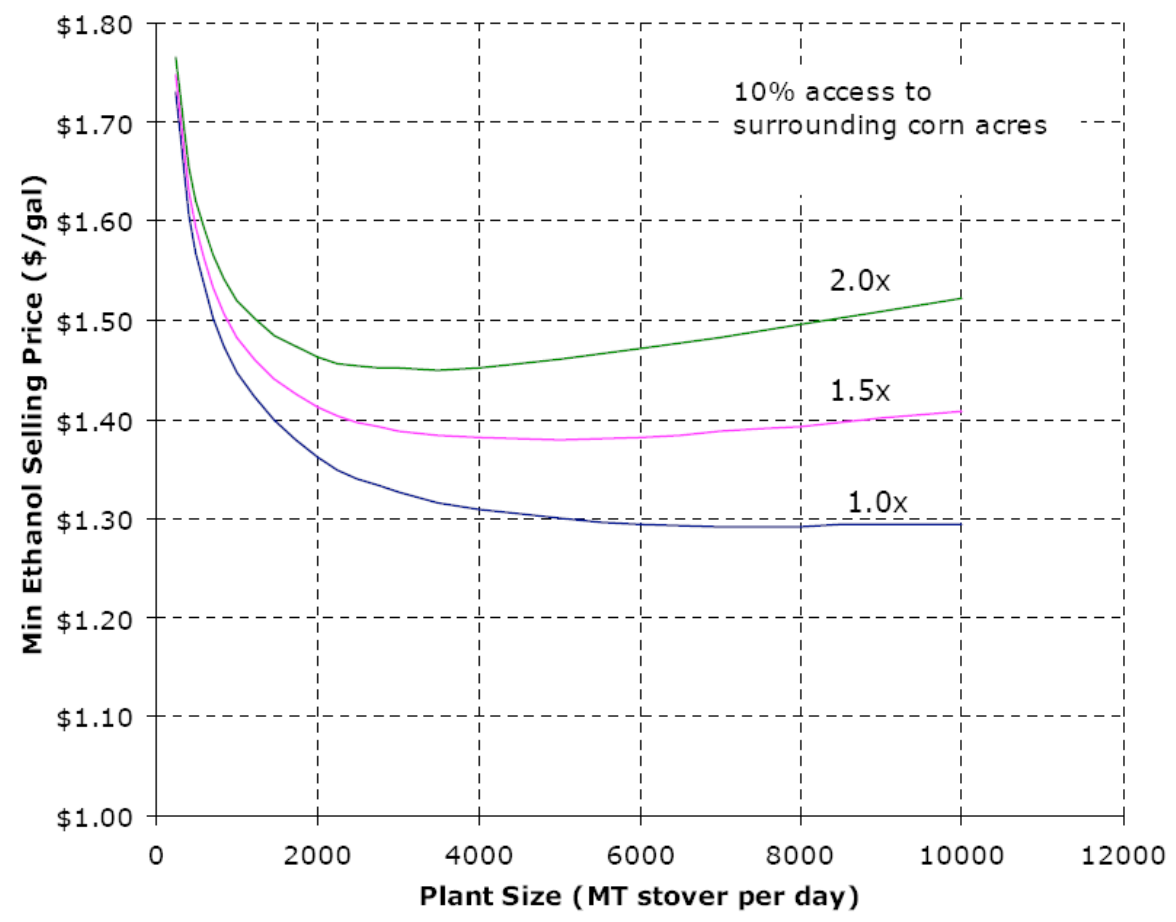

Extracted with permission.

Fig. 2.6. Ethanol price as a function of plant size and hauling cost (\#/ton-mile).2.4 
The process energy cost constitutes 6 percent of the total ethanol production cost. This changes proportionally to the non-feedstock cost of the plant in Fig. 2.5.

The right plant size is thus determined by the feedstock costs. Due to the uncertainties existing in the estimates of the feedstock costs and the potential for fluctuations over time, the costs of the ethanol plant were provided by NREL for the minimum size, which is expected to remain relatively stable at 2,000 MT/day of corn stover supply.

\subsection{Thermochemical Conversion Process}

Thermochemical ethanol production process described below is based on indirect steam gasification. The thermochemical pathway can use a wide range of biomass feedstocks because it uses a combustion-based technology to convert the biomass to ethanol. Typical feedstocks considered for thermochemical refinery include forest resources such as forest products and residues, pulp and paper industry byproducts, wood wastes and residues, municipal and yard wastes, etc. The target cost of ethanol production is $\$ 1.01 / \mathrm{gal}$, which is competitive with the corn-ethanol price of $\$ 1.07 /$ gal. The NREL design report on thermochemical conversion for ethanol production $^{2.6}$ was used as the basis for this analysis.

\subsubsection{Feedstock input (quantity, form, and storage)}

Hybrid poplar wood chips were used as the feedstock by NREL in performing the detailed analysis in their report, ${ }^{2.5}$ and will be used here as a basis for the synergistic analysis. The total availability of forest resources in the United States is expected to be $140 \mathrm{MT} / \mathrm{yr}$. This resource is classified as an "existing and unexploited resource" by the billion-ton biomass study, ${ }^{2.1}$ and thus is available for the initial plants in the 2012 or later time frame. The design used by NREL would require 700,000 MT/yr. The primary means of transportation of the wood chips to the plant is envisioned to be by truck, although rail transport is also a possibility. Assuming a moisture content of 50 percent in the feedstock, and a truck capacity of 25 tons, 176 truck deliveries would be necessary per day. The feedstock is expected to be stored in a pile on site, prior to being transported to the first unit operation via conveyer belts.

\subsubsection{Overall layout of the plant (size, interfaces, siting issues)}

The typical size of a thermochemical conversion based ethanol biorefinery is about $70 \mathrm{MM}$ gal/yr alcohol product. The feedstock basis for the analysis was 2,000 MT per day, similar to the biochemical conversion study. Note that the thermochemical process results in mixed alcohols production. Thus, it produces about $56 \mathrm{MM}$ gallons of ethanol per year, and $14 \mathrm{MM}$ gal/yr of mixed higher alcohols. The plant includes seven main areas including feed handling and preparation, gasification, gas cleaning and conditioning, alcohol synthesis, alcohol separation, and heat and power systems. The gas cleaning and conditioning step includes a tar reformer and a combustor. The details of the plant energy demands and other characteristics are listed in Table 2.5. 
Table 2.5. Characteristics of a thermochemical conversion-based ethanol refinery.

\begin{tabular}{|c|c|}
\hline Construction Phase & Operational Phase \\
\hline \multicolumn{2}{|c|}{ TIME TO CONSTRUCT } \\
\hline A: Site preparation & 1 month \\
\hline B: Construction & 2.5 years \\
\hline C: Startup testing & 1 month \\
\hline TOTAL & $2.5-3$ years \\
\hline \multicolumn{2}{|c|}{ INFRASTRUCTURE } \\
\hline Truck & \multirow{2}{*}{$\begin{array}{l}\text { Rail or truck transport for feedstock } \\
\text { transportation required. }\end{array}$} \\
\hline Rail & \\
\hline \multicolumn{2}{|c|}{ SITE CHARACTERISTICS } \\
\hline Electric Grid & none \\
\hline \multicolumn{2}{|c|}{ WET COOLING TOWER } \\
\hline Water supply & $<800 \mathrm{gal} / \mathrm{min}$ \\
\hline \multicolumn{2}{|c|}{ SYSTEMS } \\
\hline Power thermal & 97.8 MWt \\
\hline Power electric grid & None \\
\hline House load & $8 \mathrm{MWe}$ \\
\hline \multicolumn{2}{|c|}{ STEAM } \\
\hline \multirow{3}{*}{$\begin{array}{l}\text { Process steam needs } \\
\text { (mass flow rate in kg/sec) }\end{array}$} & $482^{\circ} \mathrm{C}, 850 \mathrm{psia}$ \\
\hline & $202^{\circ} \mathrm{C}, 65$ psia $(23)$ \\
\hline & $195^{\circ} \mathrm{C}, 25$ psia (92) \\
\hline \multicolumn{2}{|c|}{ OPERATIONS } \\
\hline Availability date & $>2012$ \\
\hline Plant availability & $96 \%$ \\
\hline Plant life & 20 years \\
\hline \multicolumn{2}{|c|}{ STAFFING } \\
\hline Operations & $\sim 60$ personnel \\
\hline
\end{tabular}

Because the feedstock for the thermochemical biorefineries includes forest resources and lignocellulosic wastes, in addition to the agricultural residues and energy crops, the siting of these biorefineries may depend on variables other than feedstock transportation cost alone. A discussion of the variables is beyond the scope of this study, but a geographical analysis of the feedstock availability may be reflective of the biorefinery siting potential. A comparison of the ethanol production potential based on feedstock availability is included in Chapter 4, which provides an insight into the co-siting of the nuclear power plants with thermochemical biorefineries. 


\subsubsection{Major components that make up the refinery and their role during production}

Feed preparation. The feedstock (wood chips) are conveyed through a magnetic separator, a screen, and then to a rotary drum drier, where they are dried to 5 percent moisture content, before being sent to the gasifier. The drying agent is hot flue gas from the tar reformer and the char combustor.

Gasification. The feedstock is converted to char and synthesis gas (syngas), essentially consisting of $\mathrm{CO}, \mathrm{H}_{2}, \mathrm{CO}_{2}, \mathrm{H}_{2} \mathrm{O}, \mathrm{CH}_{4}$ and traces of ammonia, hydrogen sulfide and other gaseous alkanes in a low pressure, fluidized bed gasifier. This is accomplished using steam as a partial oxidation reagent at a concentration of 0.4 $\mathrm{lb} / \mathrm{lb}$ of bone-dry feed. Steam is also used as the fluidizing agent. An inert olivine sand mixed with magnesium oxide provides the heat. The char produced in gasification is separated using cyclones and burned in a combustor, and the heat generated is used to reheat the olivine sand. The temperature of the gasifier and the combustor is self-controlled and is about $889^{\circ} \mathrm{C}$ and $995^{\circ} \mathrm{C}$, respectively. The $\mathrm{H}_{2}$-toCO ratio in the exit of gasifier is 0.6 .

Gas cleanup and conditioning. This section prepares the syngas for the alcohol synthesis reactor. The synthesis catalyst dictates the required conditioning. The tar is oxidized to additional $\mathrm{CO}$ and $\mathrm{H}_{2}$, the particulates are removed by quenching, the acid gases $\left(\mathrm{CO}_{2}\right.$ and $\left.\mathrm{H}_{2} \mathrm{~S}\right)$ are removed via amine scrubber, and the syngas is compressed. The catalytic conversion of tar can remove the hydrocarbons, but the status of the technology is not yet sufficient for commercial implementation. Ongoing research is expected to develop the technology to the level needed for commercialization. The target for 2012 (used in the plant design) is based on 99.9 percent conversion of the tar. The operation of the tar reformer is isothermal at $889^{\circ} \mathrm{C}$, with heat provided for the endothermic reaction via catalyst bed heating.

An amine system is used to remove the $\mathrm{H}_{2} \mathrm{~S}$ and the $\mathrm{CO}_{2}$ down to $50 \mathrm{ppmv}$ and 5 mol\%, respectively. A heat duty of 2660 Btu per pound of $\mathrm{CO}_{2}$ is required. The $\mathrm{H}_{2} \mathrm{~S}$ is converted to elemental sulfur using the LO-CAT process, and the $\mathrm{CO}_{2}$ is vented to the atmosphere.

The syngas is cooled to $149^{\circ} \mathrm{C}$ using heat exchangers coupled to the steam cycle. Additional cooling occurs via water scrubbing, also removing ammonia, residual tar and particulates. The cooling water requirement is determined by setting the exit temperature to $43^{\circ} \mathrm{C}$. The syngas stream is cooled down to $60^{\circ} \mathrm{C}$, and then compressed using five stage centrifugal compressors system (K301) with interstage air cooling.

Alcohol synthesis. A 3-stage steam-driven compressor, requiring $7 \mathrm{MW}$ power, takes the syngas to 1000 psia and $300^{\circ} \mathrm{C}$. The synthesis reactor producing alcohols is a fixed-bed catalytic bed with a molybdenum disulfide catalyst. This catalyst is tolerant to $\mathrm{H}_{2} \mathrm{~S}$ concentrations permitting a maintained inlet $\mathrm{H}_{2} \mathrm{~S}$ concentration of 50 ppm. The $\mathrm{CO}_{2}$ requirement of this catalyst is currently under study. The catalyst 
requires a $\mathrm{H}_{2}: \mathrm{CO}$ ratio of 2.0, but is capable of water-gas shift reaction converting water and $\mathrm{CO}$ to $\mathrm{H}_{2}$ and $\mathrm{CO}_{2}$, thus reducing the need for high inlet concentrations of $\mathrm{H}_{2}$. This reaction is highly exothermic, converting some of the water to steam, and helping with temperature control in the reactor.

The effluent from the reactor is cooled to $43^{\circ} \mathrm{C}$ using heat exchange with several cooler process streams, air-cooled exchangers, and cooling water, while maintaining high pressure. The outlet gas goes to a knock-out drum to separate the liquid alcohols from the unconverted gases. The liquids are sent to further purification and the gases are superheated to $816^{\circ} \mathrm{C}$ and sent through an expander to generate power. The pressure of the gas stream is dropped from 970 to 35 psia prior to being recycled to the tar reformer. It can be recycled back to the synthesis reactor inlet; however, this results in higher $\mathrm{CO}_{2}$ levels in the recirculating gas loop. A 5 percent purge stream is sent to fuel combustion.

Alcohol purification. The mixed alcohol stream is de-gassed, dried and separated into three streams: methanol, ethanol and mixed higher molecular weight alcohols. The methanol stream is used to back-flush the molecular sieve drying column, and is completely recycled to the inlet of the alcohol reactor to help increase the ethanol yield. The ethanol and higher alcohols streams are cooled and sent to product storage.

After gas separation from the alcohol stream exits the synthesis reactor, it is heated prior to entering the molecular sieve dehydrator via cross-exchange with steam. The molecular sieve is regenerated via decompression and methanol wash. Two dehydration columns are used in parallel, with one in operation and other in regeneration.

The dried alcohol mixture is sent to a distillation column to separate the methanol from the top. The bottoms contained the mixed higher alcohol stream, which is a coproduct. The top stream is sent to second distillation column to separate the methanol. The ethanol stream thus produced has a maximum of $0.5 \mathrm{~mol} \%$ methanol.

Steam system and power generation. The thermochemical ethanol plant design is based on self-sufficiency in terms of energy needs. This is achieved using a portion of the feedstock for energy production. Additionally, a significant portion of the heat needed in the process (in the form of steam, or otherwise) is obtained via energy capture from hot process and effluent streams. The steam demands for the process include the gasifier, amine system reboiler, alcohol purification reboilers, and the LO-CAT preheater. Of these, only the steam to the gasifier is a direct steam requirement, the rest are all energy needs for heat exchangers that can potentially be supplied by other means (electrical heating, etc.). A substantial portion of the heat demands is met by indirect heat exchange of process streams.

Power generation occurs via a process expander using the unconverted syngas before being recycled to the tar reformer. The total power needs of the plant are 
about $8 \mathrm{MW}$, which is produced using the gasifier effluent stream combined with a turbine.

\subsubsection{Simplified process flow diagrams}

Figure 2.7 shows a block flow diagram of the process. All the major processes are linked to the heat and power system to either extract or supply energy for the process. The energy balance and integration of this plant is extremely important for efficient operation. The only products are the ethanol and the higher alcohol streams. The amount of electricity produced is just sufficient to meet the needs of the plant.

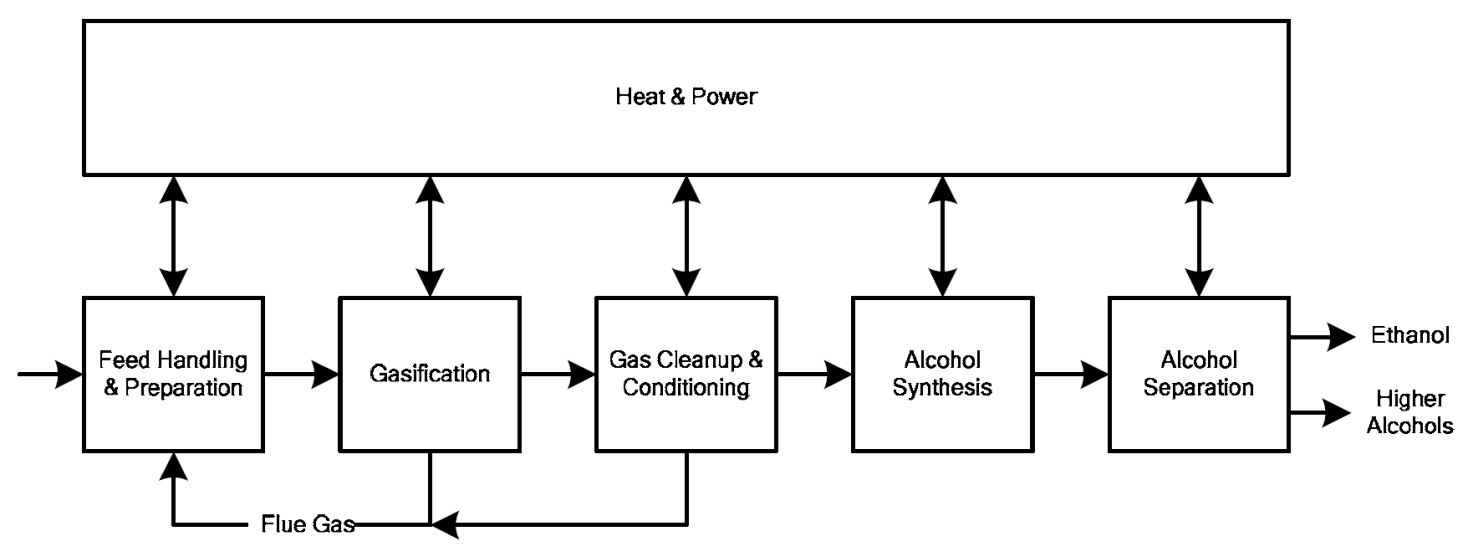

Extracted with permission.

Fig. 2.7. Block flow diagram for thermochemical conversion of biomass feedstocks to ethanol. 2.6

Table 2.6 specifies the major heat transfer streams involving steam used in the plant. All the steam is produced internally using the heat from process streams. In effect, part of the biomass feedstock is used to meet the energy needs of the plant. About 28 percent of the feed material goes into meeting the energy needs of the plant (106 MW). The total energy input in the form of the feedstock is $372 \mathrm{MW}$ (1270 MM Btu/hr). The energy needs for the plant can be divided into four different categories.

1. Electricity for plant operation: $\quad$ 7.99 MW

2. Direct steam for gasifier: $1.21 \mathrm{MW}$

3. Indirect steam for heating applications: $55.4 \mathrm{MW}$

4. Steam for compressor applications: $\quad 41.1 \mathrm{MW}$ Total $\sim 106 \mathrm{MW}$

The details of the various streams are provided in Table 2.6. The thermochemical plant is intensively integrated with respect to the energy recovery from process streams, energy supply to streams, and operations requiring heat. As an example, the steam entering the turbine is a superheated steam produced from a combined stream of low-pressure steam from various unit operations, as shown in Fig. 2.8. The plant does not have a dedicated syngas fuel-based steam generator to produce 
power. The steam is generated by heating condensate, fresh water, and lowpressure steam with various hot streams, and then superheated using the high temperature syngas from the gasifier outlet. In addition, it should be noted that part of the power required for plant operation is produced by using expansion of the high-pressure unconverted syngas stream from 965 to 25 psia.

Table 2.6. Specifications of major heat transfer streams in lignocellulosic ethanol production plant via the thermochemical conversion pathway. Definitions for each unit operation were extracted from the thermochemical design report. 2.6

\begin{tabular}{|c|c|c|}
\hline Unit Operation & $\begin{array}{l}\text { Thermal Energy } \\
\text { Required }\end{array}$ & Steam Specifications \\
\hline $\begin{array}{l}\text { Gasifier (direct use of LP steam, as a } \\
\text { reactant in gasification reaction) }\end{array}$ & $0.12 \mathrm{MW}$ & $195^{\circ} \mathrm{C}$ and $1.7 \mathrm{~atm}(33,167 \mathrm{~kg} / \mathrm{hr})$ \\
\hline Amine reboiler & 41.1 MW & $\begin{array}{l}202^{\circ} \mathrm{C}, 4.40 \mathrm{~atm} \text { to } 110^{\circ} \mathrm{C}, 4.06 \mathrm{~atm} \\
(61,591 \mathrm{~kg} / \mathrm{hr})\end{array}$ \\
\hline Syngas compression & $34.1 \mathrm{MW}$ & $\begin{array}{l}482^{\circ} \mathrm{C}, 57.8 \mathrm{~atm} \text { to } 202^{\circ} \mathrm{C}, 4.42 \mathrm{~atm} \\
\text { and } 46.7^{\circ} \mathrm{C}, 1.13 \mathrm{~atm}(2 \mathrm{streams})\end{array}$ \\
\hline Recycle syngas compression & 7.0 MW & $\begin{array}{l}482^{\circ} \mathrm{C}, 57.8 \mathrm{~atm} \text { to } 202^{\circ} \mathrm{C}, 4.42 \mathrm{~atm} \\
\text { and } 46.7^{\circ} \mathrm{C}, 1.13 \mathrm{~atm}(2 \mathrm{streams})\end{array}$ \\
\hline $\begin{array}{l}\text { Alcohol reboiler and Methanol } \\
\text { reboiler }\end{array}$ & $\begin{array}{l}5.9 \mathrm{MW} \\
8.5 \mathrm{MW}\end{array}$ & $\begin{array}{l}202^{\circ} \mathrm{C}, 4.42 \mathrm{~atm} \text { to } 144^{\circ} \mathrm{C}, 4.08 \mathrm{~atm} \\
(23,016 \mathrm{~kg} / \mathrm{hr})\end{array}$ \\
\hline LO-CAT preheater & $<1 \mathrm{~kW}$ & $\begin{array}{l}377^{\circ} \mathrm{C}, 4.40 \text { atm to } 110^{\circ} \mathrm{C}, 4.06 \mathrm{~atm} \\
(51.7 \mathrm{~kg} / \mathrm{hr})\end{array}$ \\
\hline
\end{tabular}




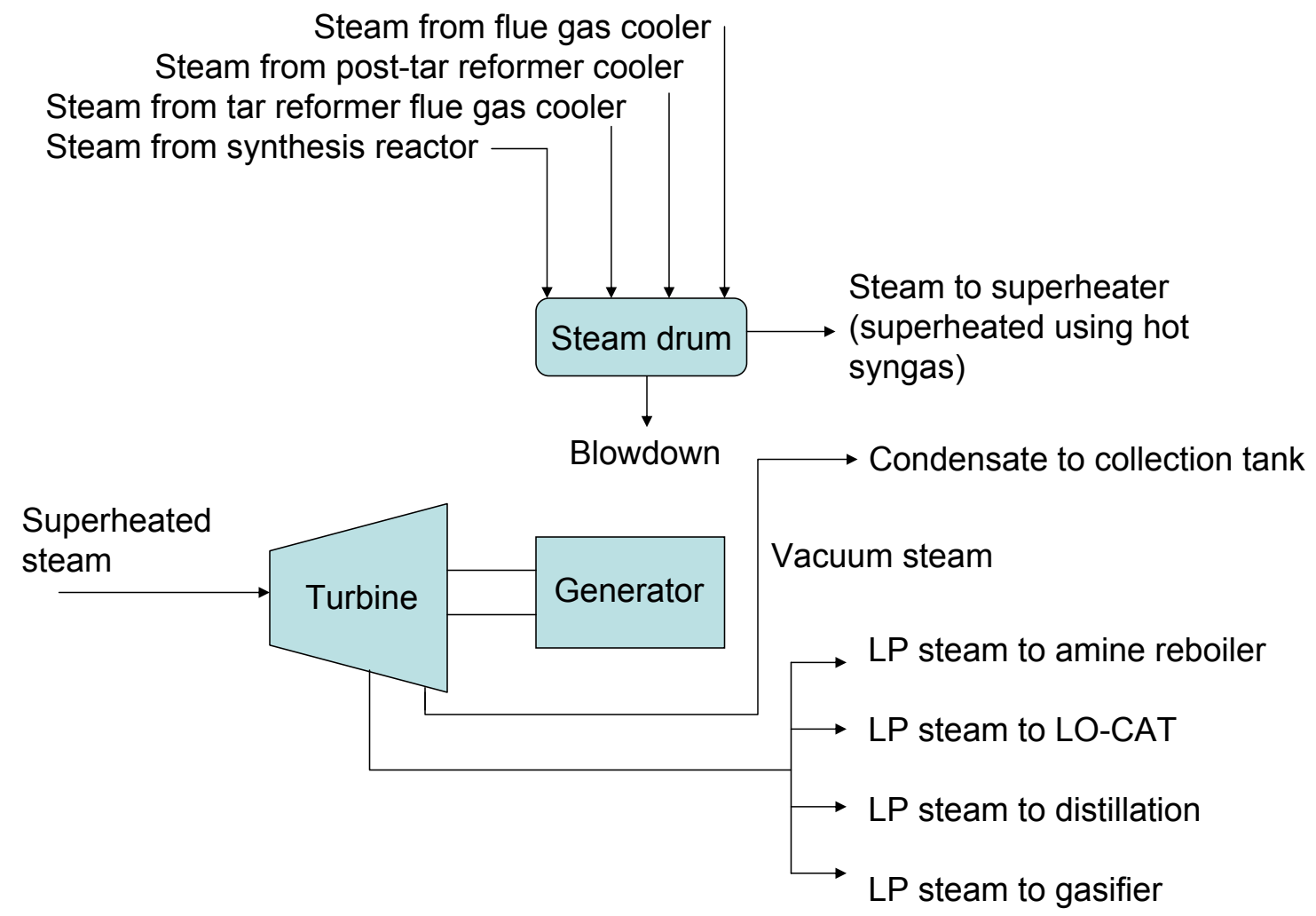

Fig. 2.8. A simplified schematic of the steam and power generator system showing various process streams used to make steam and low-pressure streams extracted from the turbine for use throughout the plant.

\subsubsection{Interfaces with other natural resource systems (e.g., water resources)}

Cooling water is used for various process cooling needs throughout the plant. These include cooling of the sand/ash from gasifier, the syngas itself after much of the heat is removed via steam generation, the LO-CAT absorbent, the reacted syngas-liquid stream to condense and remove the liquid, end product coolers, and the steam turbine condenser exiting the steam turbine. Make-up water for the cooling tower is needed at $14.7 \mathrm{psia}$ and $16^{\circ} \mathrm{C}$ at the rate of $38,400 \mathrm{~kg} / \mathrm{hr}$. This is $\sim 1.94 \mathrm{gal} / \mathrm{gal}$ of ethanol. Water losses include evaporation, drift and tower basis blowdown.

Other resources include air, which is also used for cooling purposes. A storage tank for firewater is also included in the design $(600,000$ gal).

\subsubsection{Product output (quantity, form, storage, transportation)}

The products from the plant include $56 \mathrm{MM} \mathrm{gal} / \mathrm{yr}$ of ethanol and $\sim 14 \mathrm{MM} \mathrm{gal} / \mathrm{yr}$ of mixed higher alcohols. These are stored to a maximum capacity of 5 days of production. 


\subsubsection{Waste from process (form, quantity, hazard level, storage, removal)}

Minimal waste is produced from the plant except for flue gases, carbon dioxide and water vapor, which are vented to the atmosphere.

\subsubsection{Expected staffing levels of plant}

The staffing at the thermochemical plant is expected to be similar to the biochemical plant.

\subsubsection{Expected lifetime of plant}

The operational lifetime of the plant is expected to be twenty years.

\subsection{Summary}

The U.S. Department of Energy has initiated a program to support commercialization of biomass-to-ethanol conversion technologies in order to produce alternate transportation fuels to reduce the nation's dependence on oil. The biomass feedstock potentially available for ethanol production is on the order of 1.3 billion tons. Two major routes exist for conversion of biomass to ethanol: biochemical fermentation-based and thermochemical conversion-based routes. DOE has partially funded projects to build seven small-scale and six full-scale biorefineries to help offset the initial risk of technology maturation. The goal of these activities is to demonstrate pilot-scale plant performance by 2012 .

\subsubsection{Biochemical refinery characteristics}

The biochemical conversion-based process uses biomass feedstocks such as agricultural residues and perennial grasses such as switchgrass for ethanol production. The conversion process involves biomass pretreatment, saccharification, fermentation and product recovery. The energy required for the process (104 MW thermal and 11.8 MW electric) is obtained by burning lignin, which is not converted during the process (constitutes $\sim 20-30$ percent of total biomass), and other residual biomass components that remain unconverted in a boiler/turbogenerator. The plant is self-sufficient in terms of energy usage and produces excess electricity (18.6 MW), which is sold to the grid. The plant is very well-integrated with respect to the energy production and utilization, and requires steam at three different conditions, which is produced by the boiler (Table 2.3) and used for biomass pretreatment, fermentor heating, and product distillation.

The process economics is influenced by feedstock cost, which dictates the overall plant capacity. The transportation cost limits the distance over which feedstock can be collected, which is typically a 50-mile radius around the plant. 


\subsubsection{Thermochemical refinery characteristics}

The thermochemical conversion-based process uses gasification to convert all feedstock material to syngas, which is then catalytically converted to alcohols. This is a high temperature, high-pressure process requiring significant heat input. However, the energy added into the system is recovered from the product streams via steam generation, keeping the net energy requirement low (98 MW). The plant also produces $8 \mathrm{MW}$ of electric power that makes the plant self-sufficient in energy. The plant needs steam at three different conditions (Table 2.5), which is produced by burning biomass (via syngas) to meet the plant energy needs. About 28 percent of the biomass feedstock goes into energy production. The overall process includes gasification, gas cleanup and conditioning, alcohol synthesis, purification and steam and power generation. The thermochemical plant is relatively complex and extremely integrated, with respect to the steam production and utilization to heat feedstock, compress gases, and distill products. The overall energy balance is achieved through analysis of the hundreds of gas streams throughout the plant. 


\section{Chapter 2 References}

2.1. R. D. Perlack, L. L. Wright, R. L. Graham, A. F. Turhollow, and B. Stokes, Biomass as Feedstock for Bioenergy and Bioproducts Industry: The Technical Feasibility of a Billion-Ton Annual Supply (ORNL/TM-2005-66, DOE/GO-102005-2135), Oak Ridge National Laboratory, April 2005.

2.2. J. Jechura, Ethanol potential from billion ton biomass resources, National Renewable Energy Laboratory, May 2006.

2.3. A. P. Borole, R. D. Perlack, T. West, K. Ibsen, C. Kinchin, C. W. Radtke, and B. Blackwelder, Determine which feedstock types will be used in pioneer plants (2012) and have the potential to provide moderate to large volumes, Annual Report to DOE, ORNL/NREL/INL, Oak Ridge, TN, November 2007.

2.4. A. Aden, M. Ruth, K. Ibsen, J. Jechura, K. Neeves, J. Sheehan, and B. Wallace, Lignocellulosic biomass ethanol process design and economics utilizing cocurrent dilute acid prehydrolysis and enzymatic hydrolysis for corn stover, NREL/TP-510-32438, National Renewable Energy Laboratory, 88, June 2002.

2.5. D. Glassner, J. Hettenhaus, and T. Schechninger, Corn stover collection project, Bioenergy 1998: Expanding BioEnergy Partnership, National Renewable Energy Laboratory, 1100-1110, 1998.

2.6. S. Phillips, A. Aden, J. Jechura, D. Dayton, and T. Eggeman, Thermochemical ethanol via indirect gasification and mixed alcohol synthesis of lignocellulosic biomass, National Renewable Energy Laboratory, 112, April 2007. 
Blank page 


\section{Nuclear Cogeneration Plant Characterization}

\subsection{Introduction}

Chapter 2 outlined the energy needs for both a fermentation and thermo-chemical process. A number of articles have recently been published on the use of nuclear power in combination with an ethanol refinery. ${ }^{3.1}$ However, most have concentrated on examining of the energy needs of the refineries and matching these with the output of the high-pressure turbine of a nuclear power plant. In this chapter, the principle design characteristics of a nuclear plant will be described as well as other characteristics that might enhance or affect use of a reactor as a heat source for the refinery as well as for the production of electrical energy (cogeneration).

There are no small $(<350 \mathrm{MWe})$ nuclear power plants in operation in the US at this time, nor have any small reactor designs been recently certified by the Nuclear Regulatory Commission (NRC). A number of small reactor designs have been proposed. These vary widely as to power level, coolant type, fuel type, etc. Five of these have reached a stage in their design such that the designers have initiated discussion with the NRC. These are:

1) The Pebble Bed Modular Reactor (PBMR), a 165 MWe (400MWt) helium-cooled, hightemperature reactor using graphite-based fuel in a pebble form. ${ }^{3.2}$

2) The Modular High Temperature Gas-Cooled Reactor (MHTGR), which is a $150 \mathrm{MWe}$ (350MWt) high-temperature, helium-cooled reactor using small graphite fuel spheres in a prismatic graphite matrix. ${ }^{3.3}$

3) The Super Safe Small and Simple (4S) reactor, a 10 MWe reactor using metal fuel and cooled by liquid sodium. ${ }^{3.4}$

4) The NuScale reactor-a variant of the Multi-Application Small Light Water Reactor (MASLWR) design. The MASLWR reactor is a 35MWe (150MWt) light water-cooled reactor, which produces slightly superheated steam $\left(204^{\circ} \mathrm{C}\right)$ for use in electric, district heating, or desalinization. ${ }^{3.5}$ The NuScale reactor has an increased power level of 45 MWe.

5) The International Reactor Innovative and Secure (IRIS) plant is a $335 \mathrm{MWe}(1005 \mathrm{MWt})$ reactor using light water as a coolant. ${ }^{3.6}$

Because the bioethanol refineries use low-temperature steam in their processes, it seems reasonable that either the NuScale or IRIS reactors may be best suited for cogeneration. Of these two, the IRIS reactor most nearly matched the steam conditions required by the bioethanol refineries and also has the most publically available design information. It was therefore chosen as a representative plant for this analysis. 


\subsection{Nuclear Power Plant Steam Cycles}

Commercial nuclear power plants generate power by using steam in the form of a regenerative, Rankine cycle with reheat. This is the same cycle that the IRIS and the MASLWR are expected to use. The PBMR uses a He system, and has proposed a Brayton or gas turbine to generate power. Some fossil systems use a combined cycle to generate power.

It is important to understand the configuration, heat balance, and mass flow rates for the steam system of a nuclear power plant in order to better understand where steam could be made available to power an ethanol refinery. No detailed description of the steam system configuration, heat balances and mass flow or waste heat removal system is available for the IRIS or MASLWR plants in the open literature. Therefore, this section will describe these systems as currently found in typical large commercial pressurized water nuclear plant (3000 MWt, 1000MWe). ${ }^{3.7}$ The information described is generally applicable to any nuclear power plant using regenerative, Rankine cycle with reheat. Figure 3.1 shows a typical heat balance for the steam side of a pressurized water reactor. The mass flow rates for the IRIS reactor would be about one fourth of those shown in Fig. 3.1; however, the process flow and general pressure and temperature conditions are expected to be similar, with one exception. The large commercial reactors generally operate at near-saturated steam conditions. IRIS proposes to operate at about $44^{\circ} \mathrm{C}$ superheat on the inlet of the highpressure turbine. Figure 3.2 shows the arrangement of the low-pressure steam system, and Fig. 3.3 shows the mass flow rates through the system.

Steam is produced by a set of steam generators at saturation conditions of $272^{\circ} \mathrm{C}$ and 832 psia (Figs. 3.1 and 3.2). Prior to entering the high-pressure (HP) turbine some hightemperature steam is bled off to power turbine-driven feed water pumps and other plant systems such as ejectors, and some steam is sent to reheaters [used to super heat the steam prior to entering the low pressure turbine (reheat portion of the Rankine cycle)]. About 9 percent of the mass is extracted before it reaches the HP turbine. As it passes through the turbine, some steam is extracted for more reheating, and some is lost due to moisture separation, such that about 65 percent is available for use by the LP turbines. The pressure is about $160 \mathrm{psia}$, and after reheat the temperature is raised to $257^{\circ} \mathrm{C}$, about $73^{\circ} \mathrm{C}$ superheated. Generally there are multiple LP turbines connected in parallel. At various stages throughout the LP turbine, some steam is extracted and moisture is separated, such that about 51 percent of the steam enters the condenser from the outlet of the LP turbine (Fig. 3.3). This steam is generally at or near atmospheric conditions and about $100^{\circ} \mathrm{C}$. The steam is condensed to water in the condenser. The excess heat is extracted from the condenser and either sent to a cooling pond or other body of water or dumped into the atmosphere using a wet or dry cooling tower. Each pound $(.454 \mathrm{~kg})$ of steam from the LP turbine gives up $950 \mathrm{Btu}(1001 \mathrm{~kJ})$ of latent heat to the cooling water. The condensate leaving the condenser is at about $38^{\circ} \mathrm{C}$.

The moisture from the reheaters, feed water heaters, and other systems in the plant is collected and returned to the condenser so the system theoretically is closed and little makeup water is required in the steam system except to compensate for leaks. 
In order to increase the efficiency of the system the condensate (water) is reheated using steam bled from the HP and LP turbines (regenerative portion of the Rankine cycle). After reheat the water is pumped back to the steam generators at about $223^{\circ} \mathrm{C}$ where it is returned to steam thus completing the cycle.

If steam is sent to the refinery, there are various places where it could be removed, depending on the steam conditions desired and the quantity. If significant quantities of steam are removed from an existing system, one must assure that the action would not compromise the functionality of the turbine system. 


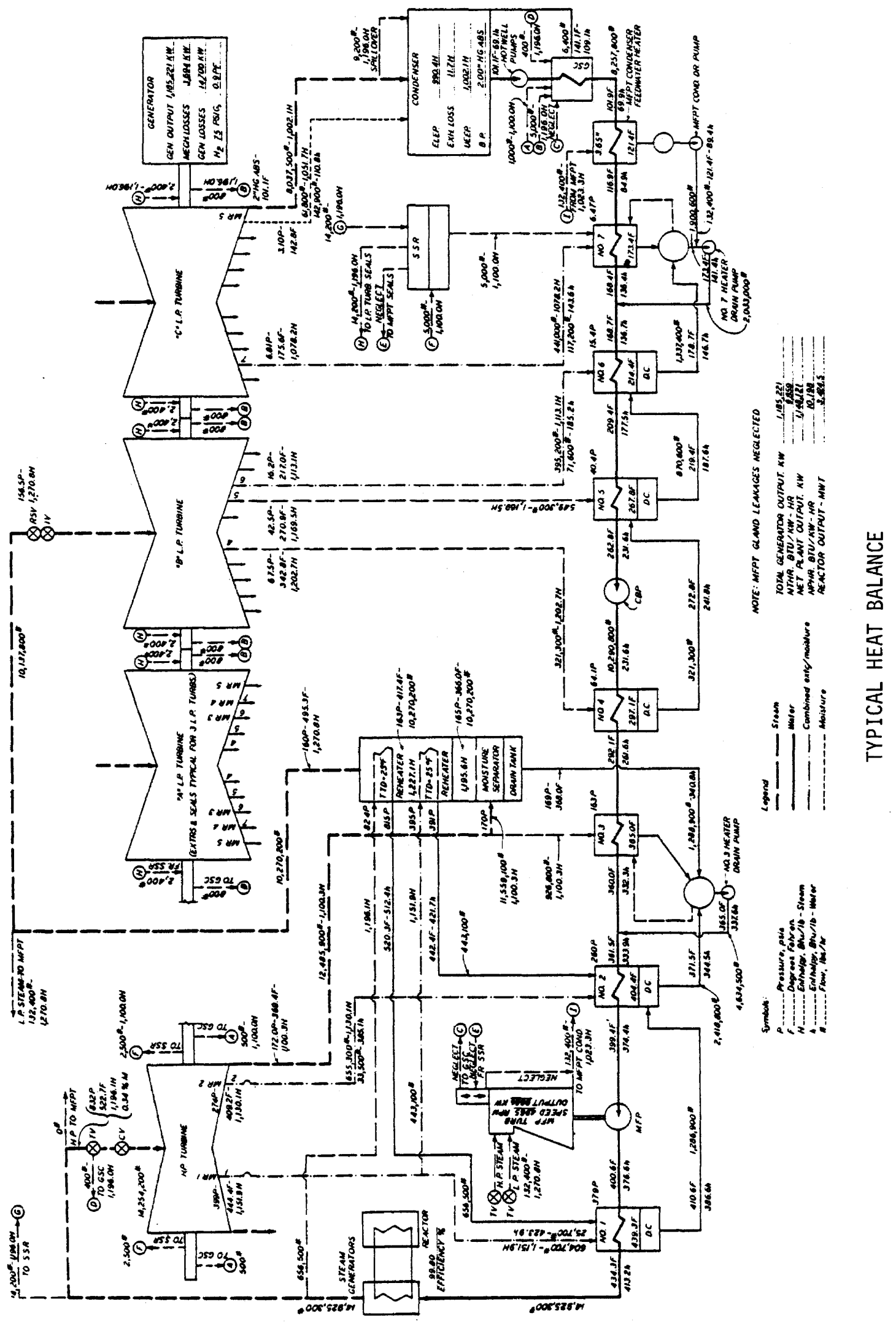

Fig. 3.1. Typical heat balance for a 1000 MWe pressurized water nuclear power plant. 


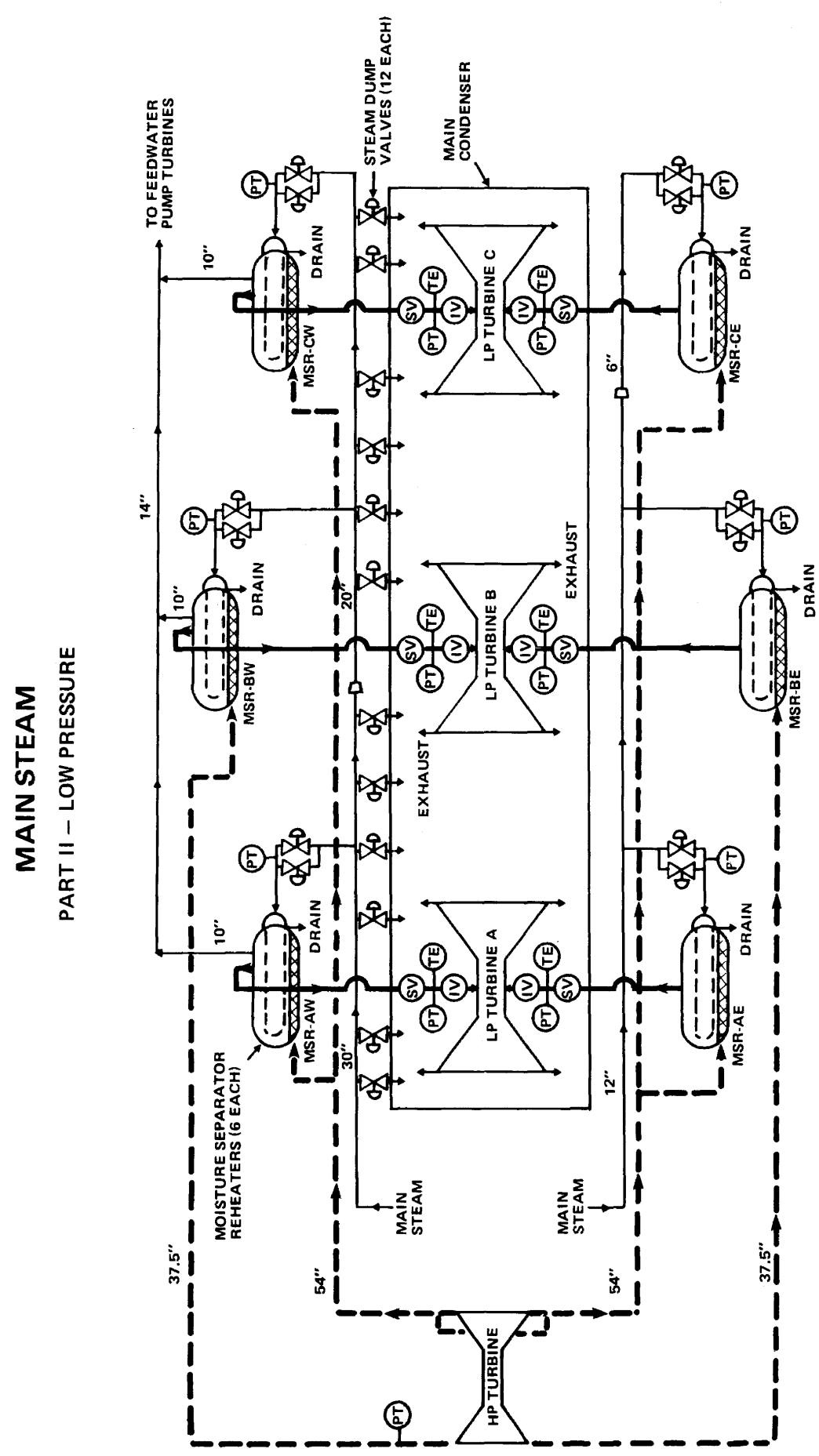

Fig. 3.2. Low-pressure steam system for a typical 1000 MWe pressurized water nuclear power plant. 


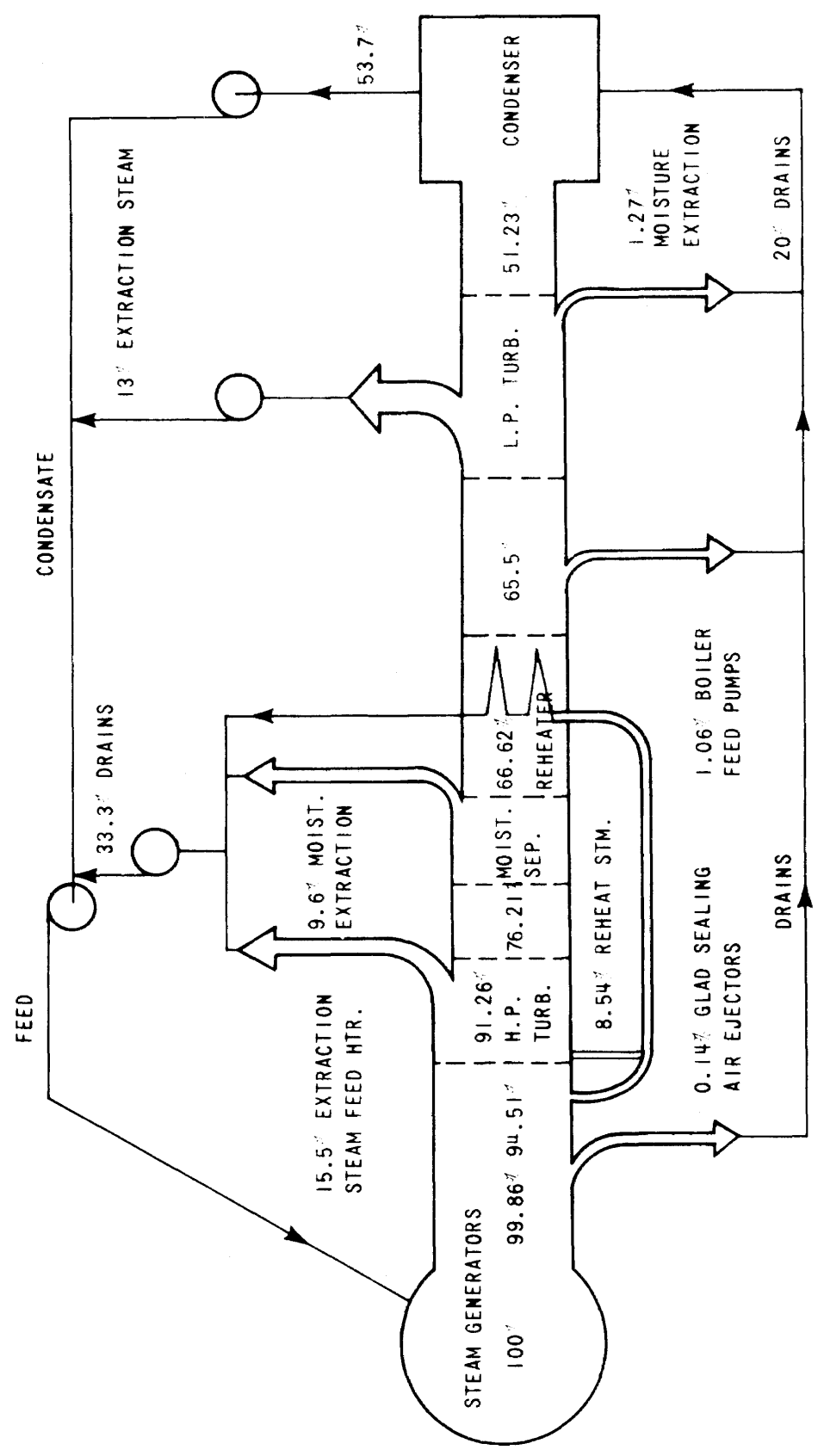

Fig. 3.3. Mass flow for the secondary side of a typical 1000 MWe pressurized water nuclear power plant. 


\subsection{Nuclear Plant Characteristics (Based on IRIS)}

\subsubsection{Energy Systems / Steam Supply}

Nuclear reactors use the fission process to generate heat in the reactor core. The IRIS plant is a pressurized-water reactor (PWR). In this type of design, water circulates through the reactor core under high pressure where it cools the reactor fuel and transports the energy from the core to a steam generator. The water is then cleaned and recirculated to the reactor core without any contact with the environment. Water is circulated on the secondary side of the steam generator at a slightly lower pressure such that superheated steam is formed. This steam passes through a turbine, condenses, and returns to the steam generator as described in Section 3.2. The turbine(s) connects to an electric generator, which produces electricity. Some of the electrical power is used by the reactor (house load), and the rest is sent to the grid. Generally, PWRs have about 33 percent efficiency, meaning that about 66 percent of the energy generated as heat in the core is deposited into the environment as low-grade energy; thus, nuclear plants' power is specified as both thermal power and electrical power. This classification is not unique to nuclear power plants. Fossil plants also dump a significant portion (>50 percent) of their heat to the environment.

\subsubsection{IRIS design}

The IRIS reactor design differs from the large nuclear PWRs in use today in that it has steam generators within the pressure vessel (Fig. 3.4). This placement allows most of the nuclear system to be manufactured off-site and shipped to the site to be assembled with the remainder of the plant, thus reducing construction costs.

The IRIS nuclear plant has a rating of 1005MWt with an electrical grid output of 335MWe. The house load is $\sim 30 \mathrm{MWe}$.

The ethanol refinery primarily needs two types of energy-steam and electrical power. Both types of energy are available from the nuclear plant. The steam mass flow rate to the high-pressure turbine of the IRIS reactor is $502 \mathrm{~kg} / \mathrm{s}\left(3.99 \times 10^{+9} \mathrm{lb} / \mathrm{h}\right)$ at a temperature of $317^{\circ} \mathrm{C}\left(602^{\circ} \mathrm{F}\right)$ and a pressure of $5.8 \mathrm{MPa}(841 \mathrm{psia})$.

The turbine systems used in PWRs consist of two stages-a high-pressure stage and at least one low-pressure stage. On average about 40 percent of the electricity is generated by the high-pressure turbine and the other 60 percent by the low-pressure turbine(s).

A schematic showing the IRIS steam supply system is shown in Fig. 3.5. The steam conditions entering the low-pressure portion of the turbine are $>181^{\circ} \mathrm{C}$ temperature and 150 psia pressure. 


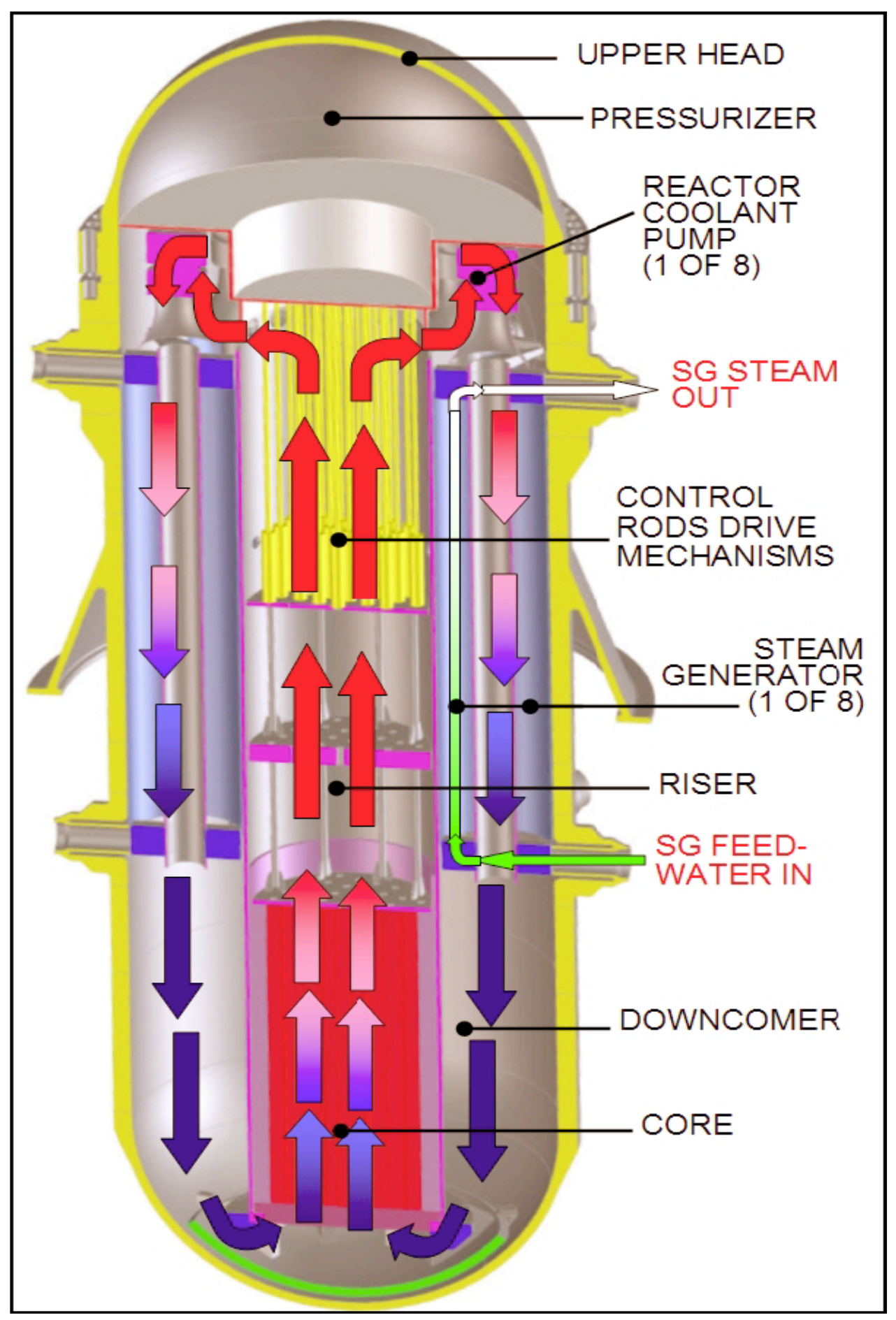

Fig 3.4. IRIS Reactor Pressure Vessel. 


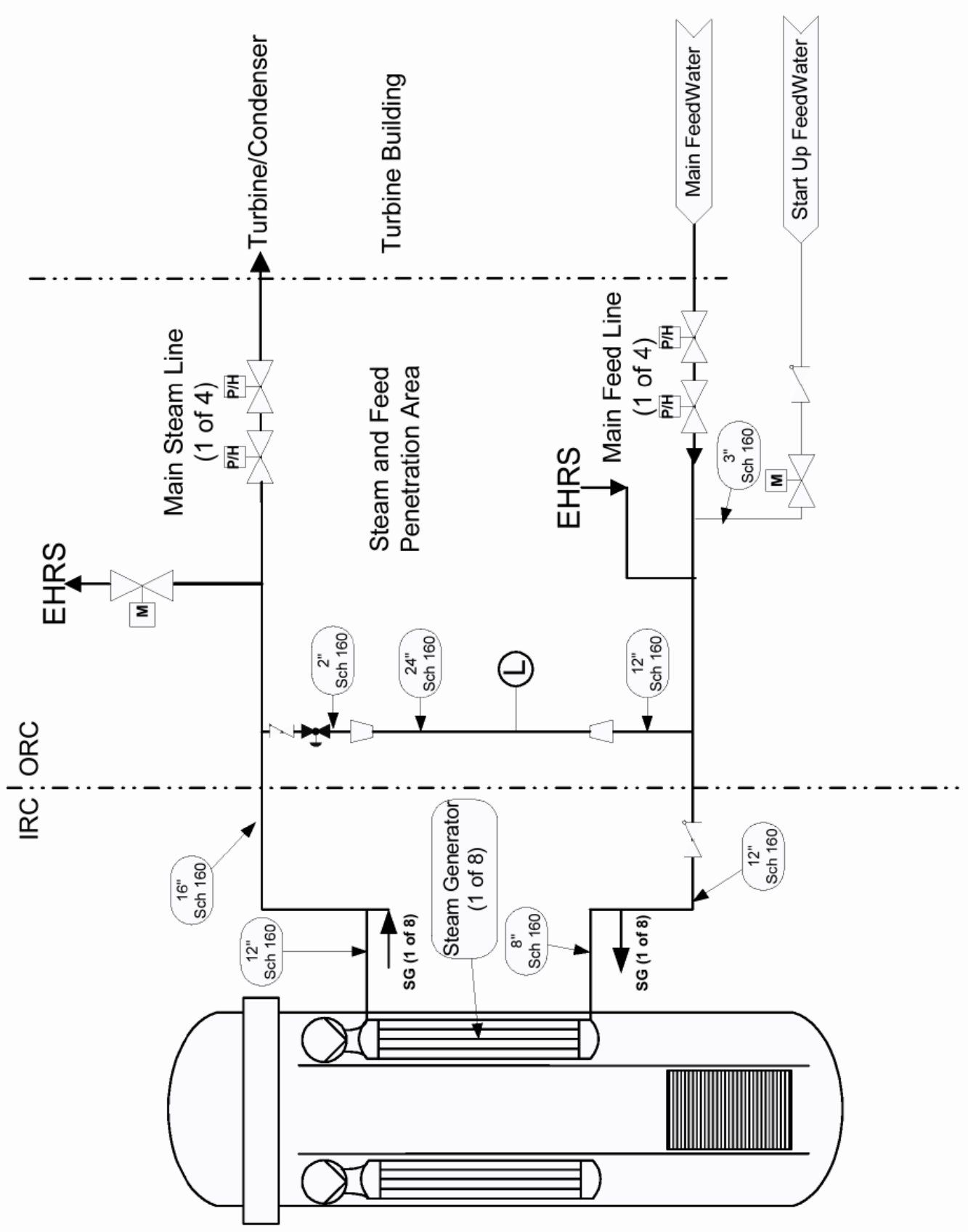

Figure 4.1-1 IRIS Steam Generator System Simplified Sketch

Fig 3.5. Steam generator system. 
Table 3.1. Characteristics of an SMR (based on IRIS design)

\begin{tabular}{|c|c|}
\hline Construction Phase & Operational Phase \\
\hline \multicolumn{2}{|c|}{ TIME TO CONSTRUCT } \\
\hline A: Licensing & 1.5 years \\
\hline B: Site preparation & 1.5 years \\
\hline B: Construction & 3 years \\
\hline C: Startup testing & 6 month \\
\hline TOTAL & 11years \\
\hline \multicolumn{2}{|c|}{ INFRASTRUCTURE } \\
\hline Truck & \multirow{3}{*}{$\begin{array}{l}\text { Rail or truck transport of construction materials, fuel } \\
\text { and spent fuel. Barge needed for IRIS reactor vessel. }\end{array}$} \\
\hline Rail & \\
\hline Barge & \\
\hline \multicolumn{2}{|c|}{ SITE CHARACTERISTICS } \\
\hline Electric Grid & $335 \mathrm{MWe}$ \\
\hline \multicolumn{2}{|c|}{ WET COOLING TOWER } \\
\hline Water supply & $>5200 \mathrm{gal} / \mathrm{min}$ \\
\hline \multicolumn{2}{|c|}{ SYSTEMS } \\
\hline Power thermal & $1000 \mathrm{MWt}$ \\
\hline Power electric grid & $335 \mathrm{MWe}$ \\
\hline House load & $33 \mathrm{MWe}$ \\
\hline \multicolumn{2}{|c|}{ STEAM } \\
\hline \multirow[b]{2}{*}{ Process steam output } & $317^{\circ} \mathrm{C}, 841$ psia \\
\hline & $>181^{\circ} \mathrm{C}, 150$ psia \\
\hline (mass flow rate in kg/sec) & $502 \mathrm{~kg} / \mathrm{sec}$ \\
\hline \multicolumn{2}{|c|}{ OPERATIONS } \\
\hline Availability date & $>2020$ \\
\hline Plant availability & $95.2 \%$ \\
\hline Plant life & 60 years \\
\hline \multicolumn{2}{|c|}{ STAFFING } \\
\hline Operations & 450 personnel \\
\hline Security Force & 75 personnel \\
\hline
\end{tabular}

\subsubsection{Operations}

The IRIS is designed for less than 1 unplanned outage per year. The availability is expected to be 95.2 percent. Refueling outages occur every 36 months, and are expected to take no more than 3 weeks based on current nuclear plant experience.

The plant is designed for a 60 -year life. It is expected to produce about $870 \mathrm{ft}^{3}$ of low-level waste (LLW) per year. It is intended to have storage capacity for 1 spent fuel core on site, and to contain about 0.5 core of fresh fuel. 
The plant is also designed to be load following with the ability to accept 50 percent reduction on power demand over a two-hour period.

\subsubsection{Construction phase of a nuclear power plant}

Nuclear power plants are federally regulated, and the NRC as a matter of federal law reviews all aspects of their construction and operation. Therefore, the construction of a nuclear plant proceeds through a series of reviews, preferably in a sequential manner. The current process is outlined in the Code of Federal Regulations 10CFR52, ${ }^{3.8}$ and consists of three major steps.

\subsubsection{Early site permit (ESP)}

The NRC can issue an ESP for approval of one or more sites for one or more nuclear power facilities separate from the filing of an application for a construction permit or combined operating license in accordance with 10 CFR Part 52. No specific design is required, but a plant parameter envelope needs to be specified. This parameter envelope includes: the number, type, and thermal power level of the facilities for which the site may be used; the boundaries of the site; the general proposed location of each facility on the site; the anticipated maximum levels of radiological and thermal effluents each facility will produce; the types of cooling systems, intakes, and outflows that may be associated with each facility; the seismic, meteorological, hydrologic, and geologic characteristics of the proposed site; the location and description of any nearby industrial, military, or transportation facilities and routes; and the existing and projected future population profile of the area surrounding the site.

An ESP is a partial construction permit and is therefore subject to all procedural requirements in 10 CFR Part 52 that are applicable to construction permits. Applications for ESPs are reviewed according to the applicable standards set out in 10 CFR Parts 50, 51, and 100 concerning applications for construction permits for nuclear power plants. ESPs are valid for 10-20 years, and may be renewed for an additional 10-20 years. ESPs address site safety issues, environmental protection issues, and plans for coping with emergencies independent of the review of a specific nuclear plant design. 


\subsubsection{Design Certification}

The NRC may certify and approve a standard plant design under Subpart B of Part 52 through a rulemaking independent of a specific site. The design certification is valid for 15 years. The issues that are resolved in a design certification have a more restrictive backfit requirement than issues that are resolved under other licensing processes. That is, the NRC cannot modify a certified design unless the modification is necessary to meet the applicable regulations in effect at the time of the design certification, or to assure adequate protection of the public health and safety. An application for a combined license under 10 CFR Part 52 can incorporate, by reference, a design certification and/or an ESP. The advantage of this approach is that the issues resolved by the design certification rulemaking process and those resolved during the ESP hearing process are precluded from reconsideration at the combined operating license stage.

NRC policy encourages early discussions (prior to a license application) between NRC and potential applicants, such as utilities and reactor designers to offer licensing guidance and to identify and resolve potential issues early in the licensing process. The Advisory Committee on Reactor Safeguards (ACRS) review of the safety aspects of the proposed design is required under Part 52.53. During this preapplication period for a design certification, the NRC holds public meetings with potential applicants to discuss advanced reactor designs to identify (1) major safety issues that could require Commission policy guidance to the staff, (2) major technical issues that the staff should resolve under existing regulations or NRC policy, and (3) any research needed to resolve identified issues.

\subsubsection{Combined Operating License (COL)}

A COL, issued under Subpart C of 10 CFR Part 52, authorizes construction of the facility in a manner similar to a construction permit under 10 CFR Part 50. However, the COL will specify the inspections, tests, and analyses that the licensee must perform. It will also specify the acceptance criteria that, if met, are necessary to provide reasonable assurance that the facility has been constructed and will be operated in conformity with the license and applicable regulations. To obtain a COL, the application must include the technically relevant information required by 10 CFR Part 50.34 for an operating license.

After issuing a COL, the Commission will verify that the licensee completed the required inspections, tests, and analyses, and that the acceptance criteria were met prior to operation of the facility. At periodic intervals during construction, the NRC will publish notices of these completions in the Federal Register. Then, not less than 180 days before the date scheduled for initial loading of fuel, the NRC will publish a notice of intended operation of the facility in the Federal Register. There is an opportunity for a hearing following construction, but the NRC will consider petitions for a hearing only if the petitioner demonstrates that the licensee has not met the acceptance criteria. Before a plant can operate, the Commission must determine that the acceptance criteria were met.

In both licensing processes (10 CFR Part 50 and Part 52), the NRC maintains oversight of the construction and operation of a facility throughout its lifetime to assure compliance 
with the Commission's regulations for the protection of public health and safety and the environment.

Figure 3.6 below, taken from NUREG/BR-0298, Rev. 2 illustrates the possible interactions between the parts of the Part 52 process (i.e., the ESP, the design certification, and the COL).

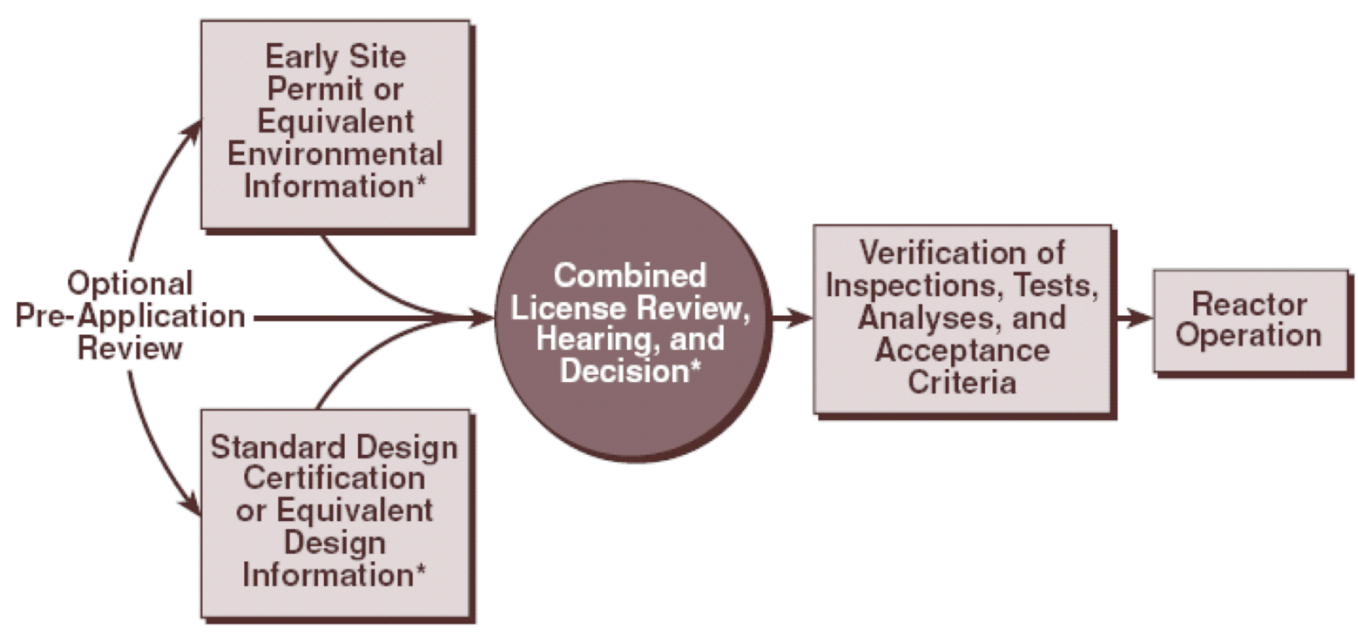

\begin{abstract}
*A combined license application can reference an early site permit, a standard design certification, both, or neither. If an application does not reference an early site permit and/or a standard design certification, the applicant must provide an equivalent level of information in the combined license application.
\end{abstract}

Fig. 3.6. Schematic of the current licensing process for a nuclear reactor.

\title{
3.3.2.4 Construction times
}

It is assumed in this study that the IRIS design concept would receive a design certification prior to any decision to use the reactor for cogeneration. For the current set of nuclear power reactors, the site permit process is taking a minimum of 3 years; some (depending on the public hearings) have taken up to 4 years, and these are for sites that currently have nuclear reactors in operation. The NRC is estimating it will take a minimum of 3 years for the COL process. The IRIS design description report ${ }^{3.6}$ assumes an aggressive process for the construction of the reactor following the issuance of the appropriate licenses and permits. The report estimates that site preparation would take 1.5 years, the actual construction would take 3 years, and start up testing would take 0.5 year. Thus, the time required from the decision to build a nuclear plant to power an ethanol refinery is made to the time the nuclear plant is operational will be approximately 11 years. The size of plant does not significantly affect the time needed to license the plant; it may be shortened if efficient construction techniques are used, but the current shortest published time for construction of these new small reactor plants is estimated to be 2 years for the MASLWR. 
Nuclear power plants are materials intensive. It is estimated that on the average, 151 cubic yards of concrete/MWe are needed, and 40 tons of steel/MWe, mostly in the form of rebar, piping, and components, in order to construct a typical large nuclear plant. ${ }^{3.8}$ The IRIS reactor design is intended to reduce this amount of material significantly. The IRIS design reflects a 75 percent reduction in volume of the containment building/MWe and $10 \% /$ MWe reduction on volume in the other support structures, along with a 50 percent reduction in valves and piping.

\subsubsection{Transportation}

The IRIS plant has a very large pressure vessel (diameter $6.8 \mathrm{~m}$, length $22.2 \mathrm{~m}$ ) and will need barge access and special lifting capability at the site. All other major components can be shipped by rail during construction. During normal operation there is not a large flow of materials in or out of a nuclear plant. During refueling or maintenance outages, there would be significant increases in flow in and out of the plant.

\subsubsection{Site characteristics}

Nuclear power plants are required by regulations (10 CFR Part 100) to have an exclusion area that acts as the site boundary; generally it is 0.5 miles in radius. This exclusion distance around the nuclear plant also acts as a security boundary as well as a radiation/safety boundary.

Surrounding the exclusion area is a low population zone, which is also set by the same regulation, and is generally about 3 miles in radius. Other factors in considering a nuclear site include large population centers no closer than about one third the distance to the outer boundary of the low population zone and the presence of man-related hazards such as dams, chemical plants, military bases, airports, and transportation routes. An emergency planning zone extends out to about 10 miles from the plant.

The IRIS plant will produce as much a $335 \mathrm{MW}$ of electricity, so a grid capable of receiving that amount of power is needed. The AC electrical supply to the reactor is nonsafety-related and is not required to perform any safety function, thus the reliability of the grid is not a regulatory issue.

The plant uses a wet cooling tower that requires about $5200 \mathrm{gal} / \mathrm{min}$ make-up water to account for evaporation of the cooling water. The tower atmospheric conditions require temperatures in the range of -10 to $+100^{\circ} \mathrm{F}$.

The site must also have a fire protection water supply, usually in the form of stored water tanks.

Four major structures make up the IRIS plant. These are (1) containment building, a steellined concrete sphere with a diameter of about $30 \mathrm{~m}$ (volume of $8200 \mathrm{~m}^{3}$ ) that houses the reactor vessel and most of the nuclear components (Figs. 3.6 and 3.4 show the reactor containment building and reactor vessel, respectively); (2) auxiliary building with a footprint of $58 \mathrm{~m} \times 41 \mathrm{~m}$ that houses the spent fuel storage and other equipment and 
encloses the containment building; (3) turbine building with a footprint of about $80 \mathrm{~m} \times 36$ $\mathrm{m}$; and (4) annex building with a footprint of $84 \mathrm{~m} \times 15 \mathrm{~m}$.

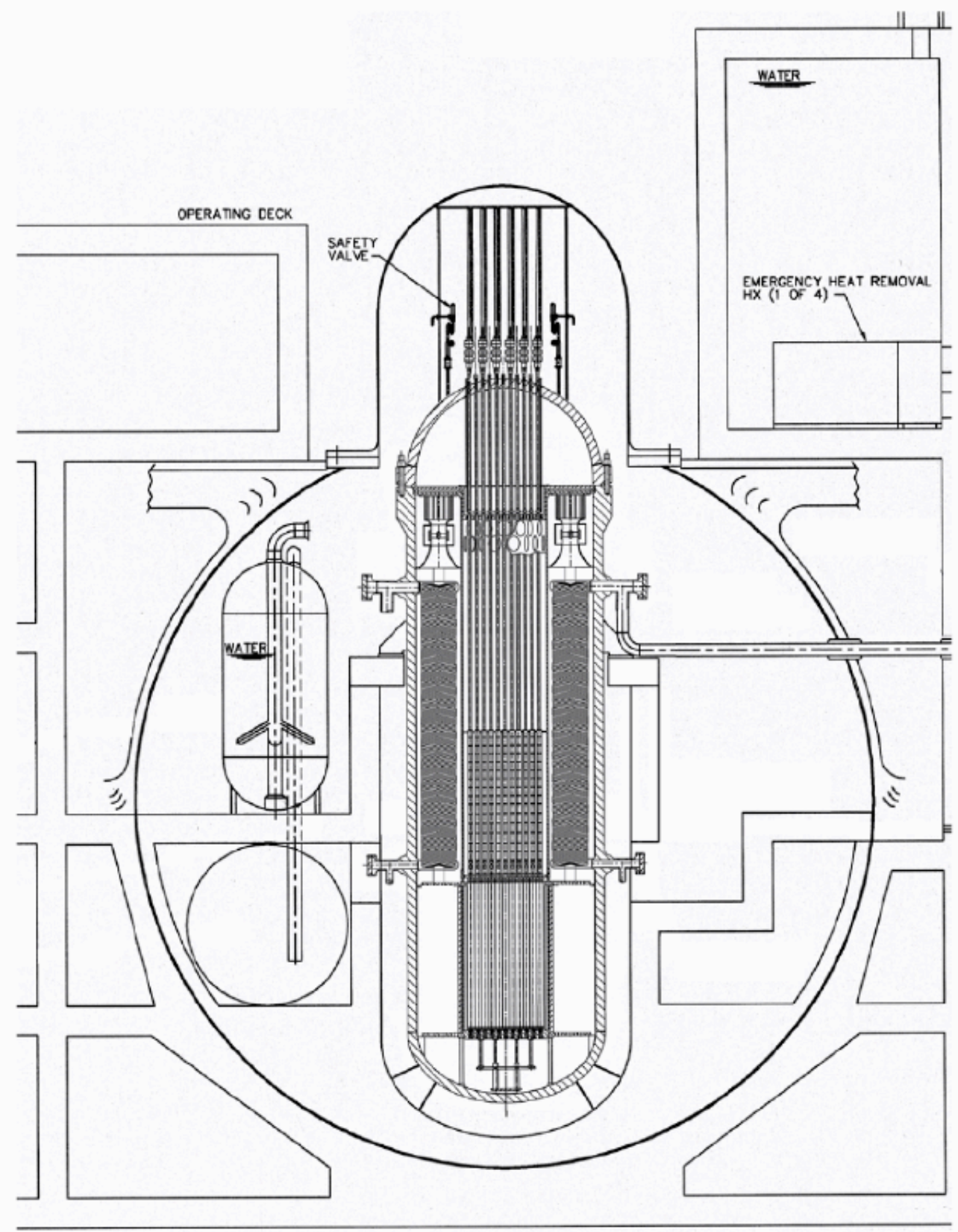

Figure 1.1-1 IRIS Spherical Steel Containment and Major Components

WCAP-16062-NP

Rev. 0

Fig. 3.7. IRIS reactor pressure vessel showing location of the reactor core and steam generators. 


\subsubsection{Staffing}

Nuclear plants require skilled and highly trained staff. These include certified operators, maintenance personnel, engineers, and management. The facility is staffed 24/7 during operation. New generation nuclear plants project fewer staff than the current fleet of reactors.

Current staffing levels for a 1000 MWe plant are about 1000. Generation 3+ plants have staffing estimates ranging from 450-700, primarily because of new technology.

The IRIS design suggests that the staffing requirements may be further reduced.

\subsubsection{Security}

In addition to the operational staff, there is a large, highly trained, and armed security force present at all times. Those working on site at a nuclear plant are required to have background checks and meet fitness for duty requirements set forth by the NRC. Access to a nuclear power plant is generally restricted and requires prenotification and escorts for nonreactor employees. The security staffing level is generally about 75 .

\subsubsection{Safety}

Safety and security programs at nuclear plants focus on protection of the workers and the public from hazards associated with nuclear power production. The principle areas of focus are associated with preventing radiation release (under both normal and accident conditions), fire protection, industrial accident prevention (high temperature steam and hazardous materials). Other safety programs deal with proper disposition, handling and storage of radioactive waste, (both low-level and spent fuel), transportation safety, criticality safety, security, and safeguards. Two levels are in place to protect workers and the general public from hazards, design and operations.

The designs are based on a defensive, in-depth philosophy that positions multiple barriers (both active and passive) between the hazards and workers and the public.

Because of the high hazards associated with a nuclear power plant rigorous attention is paid to maintaining safe operations. In this regard, nuclear power plants are required to provide extensive training (operators, maintenance, technical staff) along with a very high level of quality assurance and quality control, work control, and rigorous fitness-for-duty programs.

Finally, an extensive emergency response and management program is the last line of protection in the extreme unlikelihood that all the above barriers fail.

\subsubsection{Decommissioning}

Nuclear power plants must have a decommissioning plan in place before operations begin. Decommissioning such a facility is time-consuming and expensive. Until a final solution exists for the disposal of the spent nuclear fuel, the fuel generally remains on the site even if the rest of the plant is decommissioned. 


\section{Chapter 3 References}

3.1. C. W. Forsberg, Meeting U.S. Liquid Transport Fuel Needs With A Nuclear Hydrogen Biomass System, Proceedings of the American Institute on Chemical Engineers Annual Meeting, Salt Lake City, UT, 2007.

3.2. Website: https://www.pbmr.com/index.asp?Content=182

3.3. Website: http://www.nuc.berkeley.edu/designs/mhtgr/mhtgr.html

3.4. PSN-2008-0045, Presentation at the Preapplications Review with the NRC, February 2008.

3.5. S. M. Modro, J. E. Fisher, K. D. Weaver, J. N. Reyes, J. T. Groome, Jr., P. Babka, and T. M. Carlson, Multi-Application Small Light Water Reactor - NERI Final Report, INEEL/Ext04-01626, December 2003.

3.6. IRIS Plant Description, WCAP-16062-NP, March 2003.

3.7. Steam and Power Conversion System, Chapter 10, PWR Systems Course, NRC, 1985.

3.8. Office of the Federal Register, Code of Federal Regulations, Part 10, "Energy," January 2008.

3.9. Letter, Stan Kaplan to Senator J. McCain "Concrete and Steel Requirements for Power Plants," Congressional Research Service, November 2007. 
Blank page 


\section{Biorefinery and Nuclear Power Plant Integration: Observations and Issues}

\subsection{Introduction}

In this chapter, we will build upon the biorefinery and nuclear power plant characterizations presented in Chapters 2 and 3 to identify plant-level interface opportunities and issues. This chapter consists of four sections. These reflect the major interface areas between the ethanol refineries and the nuclear plant although many other interfaces would need to be addressed in a comprehensive analysis. The first interface issue, power and energy matching, is the area that has been the focus of several recent papers $4.1,4.2$. The second section addresses co-location and siting issues. This section raises several issues that need to be addressed before a symbiotic relationship between the two technologies can be pursued. Section 3 touches on some high level issues related to construction and licensing of co-located ethanol refineries and nuclear plants. A much more detailed study will be needed in this area before it is clear whether these two systems can be interfaced in a cost effective and timely manner. Finally, Section 4 initiates a brief discussion on the economic issues that must be addressed in order to create a business model. Tables 4.1 through 4.4 provide a comparative listing of significant biorefinery and nuclear power plant characteristics for comparison.

\subsection{Power and Energy Matching}

\subsubsection{Biochemical conversion plant}

The steam requirements of the biochemical conversion-based biorefinery (biochem plant) and the steam supply available from the nuclear plant are listed in Table 4.1. The thermal requirement of the biochem plant is about $104 \mathrm{MW}$, while the output from the IRIS nuclear plant is 1000 MW. Thus, the nuclear plant needs can easily meet the biochem plant energy. In examining the individual energy streams, it is obvious that the IRIS has sufficient capability of supplying the individual biochem plant steam needs. The steam could be extracted from either the high-pressure turbine inlet or the low-pressure turbine. In the nuclear plant, about 40 percent of the electricity comes from the HP turbine and the remainder from the LP turbine. The highest-grade steam generated in the IRIS plant, as currently designed, is $314^{\circ} \mathrm{C}$ and 841 psia. This is used as the feed to the high-pressure turbine inlet to generate electricity. Part of this steam may have to be used without the step down to lower pressure, since one of the operations in the biochem plant requires $264^{\circ} \mathrm{C}$ and 191 psia steam. The second steam line required is $165^{\circ} \mathrm{C}$ and 65 psia. The low-pressure steam generated by the turbine used in the IRIS pant design is at $>181^{\circ} \mathrm{C}$ and 150 psia, which will be sufficient to meet the needs of the second steam line. The third steam line $\left(115^{\circ} \mathrm{C}\right.$ and 25 psia) needed for the biochem plant operation can be provided by a bleed from the LP turbine. 


\subsubsection{Thermochemical conversion plant}

It is clear that the nuclear plant has the ability to supply the energy needs (106 MWt) of the thermochemical plant. The quality of the stream required, however, needs further discussion. The gas compressors used in the thermochemical plant use high-pressure steam $\left(482^{\circ} \mathrm{C}, 850 \mathrm{psi}\right)$ to drive the units. The maximum steam temperature available from the nuclear plant is $317^{\circ} \mathrm{C}$ and $841 \mathrm{psi}$. So, if the nuclear plant steam is used in the thermochemical plant, it will need to be heated further. This is possible, because the high-pressure steam used in compressors in the current thermochem plant design is produced by superheating low pressure steam coming from the tar converter-based heat exchangers with the hot syngas $\left(995^{\circ} \mathrm{C}\right)$ exiting the gasifier. However, this implies significant integration of the steam lines from the nuclear and the biorefinery plants. Additionally, part of the steam required in the thermochemical plant (gasifier feed) is needed as a reactant and not just as a heating medium, making it a consumable. This raises some concerns regarding direct use of steam from the nuclear plant in the biorefinery, which are addressed in the following section.

\subsubsection{Options for replacing the biorefinery boiler}

Previous analysis of biorefinery-nuclear power plant integation have focused on the thermal energy demand of the biorefinery, and supply of that demand with waste heat from a nuclear power plant. Two options are apparent:

- Direct replacement of the combustor/boiler with steam supplied by the nuclear power plant, or

- Redesign of the boiler to utilize thermal energy transmitted to the primary side of the boiler from the nuclear power plant via pressured water, steam, or some other working fluid (liquid salt, etc.).

Previous studies such as Reference 4.2 have focused on energy supply and balance to determine synergy between the nuclear plant and the biorefineries. The study indicated potential energy synergism between the two systems. A recent study 4.1 focused on the energy balances and economic assessment of using IRIS for supplying the energy needs of a biochem plant. It used total ethanol production of $200 \mathrm{MM} \mathrm{gal} / \mathrm{yr}$ as the basis. This is equivalent to about $5700 \mathrm{MT}$ biomass feedstock per day for a biochemical plant. Availability of this amount of biomass at one location is possible, but may lead to higher feedstock costs due to higher transportation costs. Obtaining greater than $2000 \mathrm{MT}$ /day would require going outside the 50 mile radius recommended to keep the feedstock prices below the target of $\$ 35$ per MT.

The steam produced at the nuclear plant would not be directly used for the biorefinery application due to concerns regarding contamination with radiation, etc. In the case examined in Reference 4.1 steam-to-steam heat exchangers were suggested. The losses for systems that have a large exchange of power at low 
temperature differentials have the potential for large pressure drops. Additionally, the degree of supersaturation makes a difference in the amount of pressure losses. Supersaturated steam has lower potential for pressure losses as compared to saturated steam. Thus, it is likely that higher pressure and potentially supersaturated steam will be needed from the nuclear plant. The study in Reference 4.1 did not take into account the steam piping distance that would be imposed by regulations which would further increase the pressure loss and also likely reduce the temperature. In the study it was assumed that the steam system supplying the refinery was isolated from the nuclear steam system by a heat exchanger. In the most recent study by Forsberg, 4.2 it was assumed that the steam from the nuclear plant was not isolated by a heat exchanger but transported to the refinery and then returned to the nuclear plant. This would eliminate any loss in energy transfer through the heat exchanger. This latter approach, while reducing losses, has a potential safety concern. One of the design basis accidents in a nuclear plant is a rupture in one or more primary tubes in the nuclear steam generator that contains radioactive primary water. With a ruptured tube, this water can enter the steam system and be carried to other parts of the plant and potentially be released through steam valves, turbines etc. It is likely that the steam supply to the refiner will need be to isolated from the nuclear steam system to prevent carry over of radioactive contamination to the refinery as envisioned in Reference 4.1 and therefore incur the losses associated with low efficiency heat exchangers.

\subsubsection{Impacts of eliminating the biorefinery combustor}

Perhaps the more challenging issue associated with replacing the boiler of the biorefinery with steam from a nuclear power plant is the associated elimination of the biorefinery's combustor (within the boiler).

As discussed in Chapter 2, in addition to supplying process steam and perhaps electricity for housekeeping loads within the plant, the biorefinery combustor/boiler is an integrated element of the plant byproduct and waste management process. Because there is currently no large-scale demand for lignin, this by-product of feedstock processing is used as the primary fuel for the combuster. Elimination of the combustor/boiler from a biochemical plant would "free-up" significant quantities of lignin (1800 dry MT/million gallons of ethanol, or 360 dry MT/day). While research into potential alternative uses of lignin is currently under way, in the absence of an alternative use for lignin, replacement of the biochemical refinery combustor/boiler with nuclear steam will convert this lignin stream from a fuel to a byproduct with an unknown value at this time. Additionally, as discussed in Chapter 2, the combustor consumes the lignin residue, evaporator syrup, anerobic biogas, and digestor solids, converting it to heat and flue gas (383 MT/day of evaporator dry solids, 1.6 dry MT/day of digestor solids and 15 MT/day of biogas). Elimination of the combustor would eliminate the flue gas, but would necessitate alternative waste management strategies for these byproducts/waste streams. 
In a comparison of the various steam supply options reported by Putignano et al., 4.1 it was determined that the use of lignin combustion in a CFBC resulted in the lowest price for ethanol vs. cogeneration with IRIS or a combined cycle cogeneration. The gross margin revenues were lower for the IRIS-cellulosic biorefinery option in comparison to the CFBC-based cogen option by about 13 percent. The report pointed out that the pivotal economic issue was the ability to use the excess lignin as a product rather than burn it to produce steam and electricity. If higher value products can be derived from lignin, the IRIS-biorefinery co-gen option may prove economic. A potential use of lignin to make adhesive was suggested. ${ }^{4.1}$ Other higher value products may be possible from lignin. One of the options being studied is production of lignin fibers, which offers potential use in automotive and other industries. ${ }^{4.2}$ Such alternatives may lead to a beneficial co-gen scenario with use of nuclear plant-derived steam.

\subsubsection{The matter of scale}

One observation apparent from the discussions presented in Chapters 2 and 3 and Table 4.1 relates to the size or rather the "size gap" between typical biorefineries and nuclear power plants. Current and near-term biorefineries $(\sim 70$ million gal/yr production) draw their feedstocks within a $\sim 50$ mile-radius from the plant, and require $\sim 100 \mathrm{MWt}$ equivalent process heat. The smallest commercial nuclear power plant that can be ordered today produces in excess of $3000 \mathrm{MWt}$, rejecting twothirds of this total as "waste heat."

One approach to facilitate integration might be to focus on developing the bridge between the two facilities, rather than adjusting their size. In this case, one would assume that the size and capacities of both nuclear power plants and biorefineries will remain relatively fixed, and that some combination of bridging technologies, operating protocols, and business models can be developed to enable symbiotic operation.

A different approach to integrating the plants would be to focus on reducing the size gap by scaling-up the biorefinery capacities and scaling-down the nuclear power plant capacities. This would require the development of much smaller nuclear power plants than those currently available and/or developing much larger biorefineries. Regardless of the approach employed, bridging technologies and protocols will be required to convert, transport, and recover the required energy that must be transmitted from the nuclear plant to the biorefinery. Some combination of these approaches, or other creative means to harmonize and integrate the plants is required. 
Table 4.1. Biorefinery and nuclear power plant (based on IRIS design) power and energy characteristics.

\begin{tabular}{|c|c|c|c|}
\hline System & Nuclear Plant & $\begin{array}{l}\text { Biochemical } \\
\text { Refinery }\end{array}$ & $\begin{array}{l}\text { Thermochemical } \\
\text { Refinery }\end{array}$ \\
\hline \multicolumn{4}{|c|}{ STEAM } \\
\hline HP turbine inlet temp & $317^{\circ} \mathrm{C}\left(602^{\circ} \mathrm{F}\right)$ & & \\
\hline HP turbine pressure & $\begin{array}{l}\text { 5.8 Mpa ( } 841 \\
\text { psia) }\end{array}$ & & \\
\hline LP turbine inlet temp & $>181 \mathrm{C}\left(>357^{\circ} \mathrm{F}\right)$ & & \\
\hline LP turbine inlet pressure & $\begin{array}{l}\text { 1.03 Mpa (150 } \\
\text { psia) }\end{array}$ & & \\
\hline Quality & $\begin{array}{l}\text { superheated (HP } \\
\text { inlet) }\end{array}$ & & \\
\hline Mass flow & $\begin{array}{l}502 \mathrm{~kg} / \mathrm{sec}(3.99 \\
\mathrm{X} 10+6 \mathrm{lb} / \mathrm{hr}) \\
\end{array}$ & & \\
\hline $\begin{array}{l}\text { Process steam needs } \\
\text { (mass flow rate in } \mathrm{kg} / \mathrm{sec} \text { ) }\end{array}$ & & $\begin{array}{l}268^{\circ} \mathrm{C}, 191 \text { psia }(10.3) \\
164^{\circ} \mathrm{C}, 65 \text { psia }(18.3) \\
115^{\circ} \mathrm{C}, 25 \text { psia }(1.4)\end{array}$ & $\begin{array}{l}482^{\circ} \mathrm{C}, 850 \text { psia } \\
202^{\circ} \mathrm{C}, 65 \text { psia }(23) \\
195^{\circ} \mathrm{C}, 25 \text { psia }(9.2) \\
\end{array}$ \\
\hline Power thermal & $1000 \mathrm{MWt}$ & $103.6 \mathrm{MWt}$ & $97.8 \mathrm{MWt}$ \\
\hline Power electric grid & $335 \mathrm{MWe}$ & $18.61 \mathrm{MWe}$ & None \\
\hline House load & $30 \mathrm{MWe}$ & 11.8MWe & $8 \mathrm{MWe}$ \\
\hline \multicolumn{4}{|c|}{ OPERATIONS } \\
\hline Unplanned outages & $<1 /$ yr. & No data & No data \\
\hline Plant availability & $95.20 \%$ & $96 \%$ & $96 \%$ \\
\hline Refueling outages & 36 mo. & $\begin{array}{l}\text { n/a (Maintenance } \\
\text { outage = once a year) }\end{array}$ & $\begin{array}{l}\text { n/a (Maintenance } \\
\text { outage = once a year) }\end{array}$ \\
\hline Refueling time & $\begin{array}{l}>2 \text { weeks base } \\
\text { on current plants }\end{array}$ & & \\
\hline Plant life & 60 years & 20 years & 20 years \\
\hline Power load changes & $\begin{array}{l}\text { up to } 50 \% \text { over } 2 \\
\text { hours }\end{array}$ & $\mathrm{n} / \mathrm{a}$ & $\mathrm{n} / \mathrm{a}$ \\
\hline
\end{tabular}

In Chapter 1 of this report, several candidate SMRs were mentioned that had developed sufficiently in their design such that they have initiated interaction with the NRC. The IRIS was chosen because it had steam conditions similar to those needed in the ethanol refinery. However, the capacity of the nuclear plant was nearly 10 times that needed for the $70 \mathrm{MM}$ gal/yr ethanol plant. This means that the nuclear plant would also be a co-generator of electricity, which would be sold to a utility. In its original design, the biochemical refinery also was expected to generate excess power because it was burning the lignin which produced more power than was needed for the refinery. The study Reference 4.1 showed that at least two thirds of the electrical power from the IRIS plant would still be available to sell to a utility after supplying the needs of biochemical ethanol refinery. Nuclear plants generally have an economy of scale and therefore capital and operating costs/kW may increase significantly if the plant size is reduced. An economic analysis is needed to 
determine the optimum size of a nuclear plant/biochemical ethanol refinery that will still make it economically attractive to co-locate the nuclear and the refinery plants.

An alternative option in this study would be to examine a nuclear plant that is more comparable in size to the energy needed by the biochemical ethanol refinery. Such a smaller plant might have reduced capital cost and improved siting characteristic such that it has the potential to be sited on a wide variety of sites, more adaptable to a biochemical refinery, whose site is determined by the availability of feedstock. One such SMR is the MASLWR that has a thermal power of $150 \mathrm{MWt}$, which is better matched to the refinery needs of $100 \mathrm{MWt}$ or less. It was not chosen for this study because it has a peak steam temperature of $204^{\circ} \mathrm{C}$ at 200 psia, which is not able to provide the $268^{\circ} \mathrm{C}$ and 191 psi steam needed for the pretreatment and hydrolyzate conditioning phase of the biochemical refining process considering losses. This reactor relies on passive safety systems and therefore, is somewhat tuned such that its response to accident conditions is determined by the moderator (water) parameters. It not clear without further analysis, if increasing the outlet temperature of the reactor would have an impact on the reactor safety case. This remains an area for further study. A design change in the current biochemical conversion plant may also be possible to accommodate the use of lower quality steam, however, this also requires further analysis.

\subsubsection{Outage management}

The IRIS plant is designed to minimize unplanned outages to less than 1 per year, and refueling outages to once every 3 years. Refueling outages generally last 2 weeks or more during which time critical maintenance is done on components that may not be accessible. During these periods the refinery will be faced with finding an alternative source of power or cease production, alternatively if the refinery must shutdown the reactor, the electric grid will need to be capable of transferring all the power to electricity or reduce power output. Most commercial nuclear power plants are base load and are not intended to load follow. Most of the SMRs will have the ability to have limited load following because of anticipated unreliability of the grid system. In the case of the IRIS, the reactor is designed to reduce power to 50 percent over a 2 -hour interval without adverse affects.

\subsection{Co-location/siting issues}

Tables 4.2 and 4.3 present a summary of biorefinery and nuclear power plant siting and civil infrastructure characteristics and requirements.

\subsubsection{Biorefinery siting considerations}

Location of the biorefinery is typically determined by the feedstock availability. In order to assess the co-location possibility of nuclear plants with biochemical refineries, a map of existing and potential new nuclear plants overlapping with potential biorefinery sites was created. A national level model predicting future 
biorefinery locations is not available, but the estimates of potential ethanol production per county for all counties in United States is available. Figure 4.1 shows the nuclear plant locations overlaid on a GIS map of estimated ethanol production potential for the United States. The map can be used to identify potential locations for co-locating nuclear plants with biochemical pathway-based biorefineries. The feedstocks used for determining ethanol potential in Fig. 4.2 included agricultural residues such as corn stover, rice straw, wheat straw, etc. Figure 4.2 shows a map of the nuclear plants overlaid on ethanol production potential via the thermochemical route.

Table 4.2. Biorefinery and nuclear power plant site characteristics.

\begin{tabular}{|c|c|c|c|}
\hline System & Nuclear Plant & $\begin{array}{l}\text { Biochemical } \\
\text { Refinery }\end{array}$ & $\begin{array}{l}\text { Thermochemical } \\
\text { Refinery }\end{array}$ \\
\hline \multicolumn{4}{|c|}{ SITE CHARACTERISTICS } \\
\hline Exclusion area & 0.5 mile radius & None & \\
\hline Low population zone & 3 miles & $\mathrm{n} / \mathrm{a}$ & \\
\hline Emergency planning & 5-10 miles & $\mathrm{n} / \mathrm{a}$ & \\
\hline Electric grid & 335 MWe capacity & $\begin{array}{l}20 \mathrm{MWe} \\
\text { capacity }\end{array}$ & none \\
\hline \multicolumn{4}{|c|}{ WET COOLING TOWER } \\
\hline Water supply & $>5200 \mathrm{gal} / \mathrm{min}$ & $<1000 \mathrm{gal} / \mathrm{min}$ & $<800 \mathrm{gal} / \mathrm{min}$ \\
\hline Air temp limits & minus 10 to $115^{\circ} \mathrm{F}$ & $\mathrm{n} / \mathrm{a}$ & $\mathrm{n} / \mathrm{a}$ \\
\hline \multicolumn{4}{|c|}{ BUILDINGS } \\
\hline Containment/shield & $30 \mathrm{~m} \mathrm{OD}$ & $\mathrm{n} / \mathrm{a}$ & $\mathrm{n} / \mathrm{a}$ \\
\hline Aux building & $58 \mathrm{~m} \times 41 \mathrm{~m}(190 \mathrm{ft} \times 135 \mathrm{ft})$ & & \\
\hline Turbine building & $80 \mathrm{~m} \times 36 \mathrm{~m}(260 \mathrm{ft} \times 118 \mathrm{ft})$ & & \\
\hline Annex building & $84 \mathrm{~m} \times 15 \mathrm{~m}(275 \mathrm{ft} \times 59 \mathrm{ft})$ & & \\
\hline \multicolumn{4}{|c|}{ STAFFING } \\
\hline Operations & 450 personnel & 60 personnel & 60 personnel \\
\hline Security & 75 personnel & 4 personnel & 4 personnel \\
\hline
\end{tabular}


Table 4.3. Biorefinery and nuclear power plant civil infrastructure characteristics.

\begin{tabular}{|c|c|c|c|}
\hline System & Nuclear Plant & Biochemical Refinery & $\begin{array}{l}\text { Thermochemical } \\
\text { Refinery }\end{array}$ \\
\hline \multicolumn{4}{|c|}{ INFRASTRUCTURE } \\
\hline A: Barge & vessel (required) & Not required & \\
\hline B: Rail & other equip & $\begin{array}{l}\text { Rail or truck transport for } \\
\text { feedstock transportation } \\
\text { required. }\end{array}$ & $\begin{array}{l}\text { Rail or truck transport for } \\
\text { feedstock transportation } \\
\text { required. }\end{array}$ \\
\hline \multicolumn{4}{|c|}{ STAFFING } \\
\hline Operations & 450 personnel & 60 personnel & 60 personnel \\
\hline Security & 75 personnel & 4 personnel & 4 personnel \\
\hline
\end{tabular}

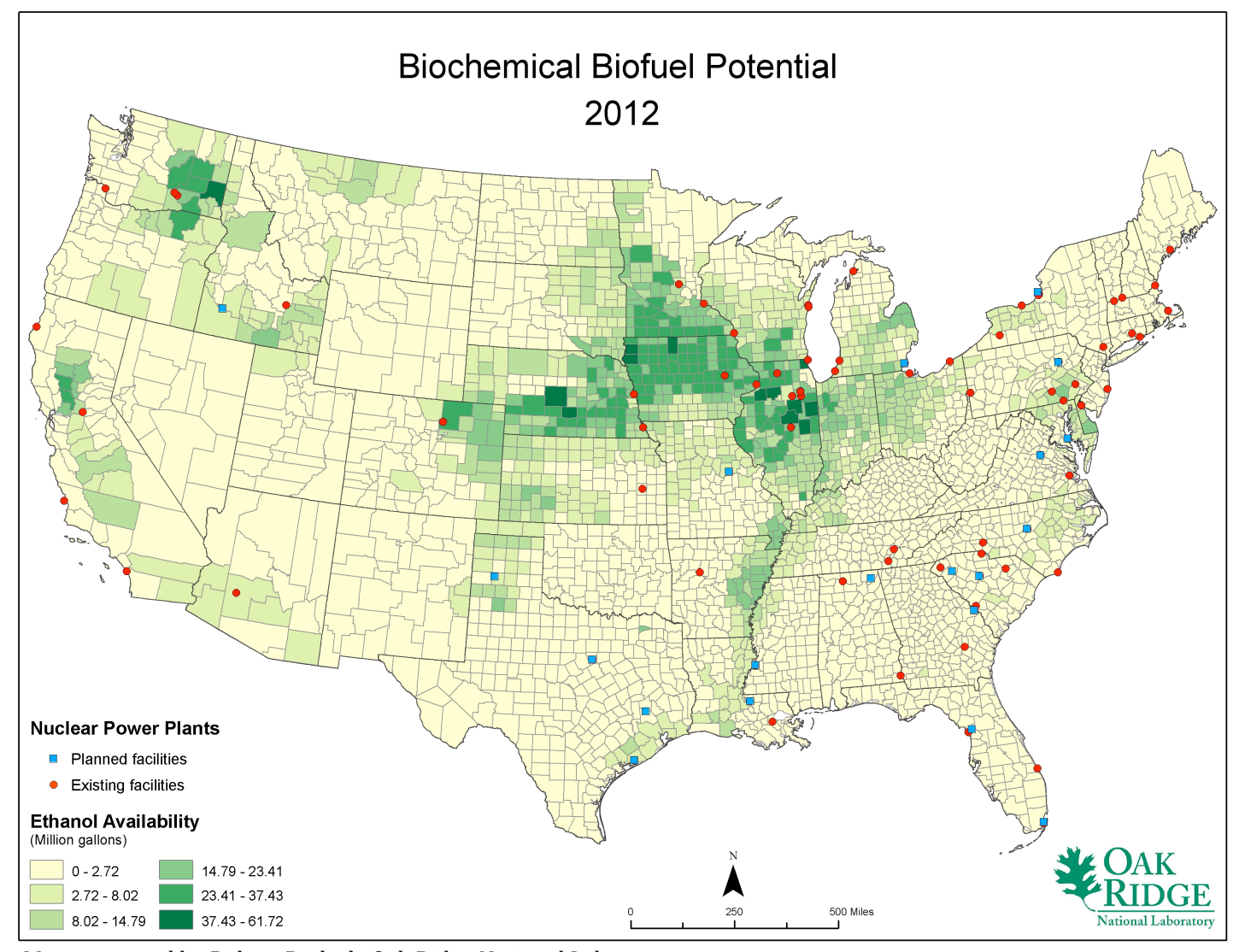

Map generated by Robert Perlack, Oak Ridge National Laboratory.

Fig. 4.1. GIS map of existing and planned nuclear facilities overlaid with estimated ethanol production potential via the biochemical conversion route of agricultural residues and other biomass feedstocks suitable for biochemical conversion. 


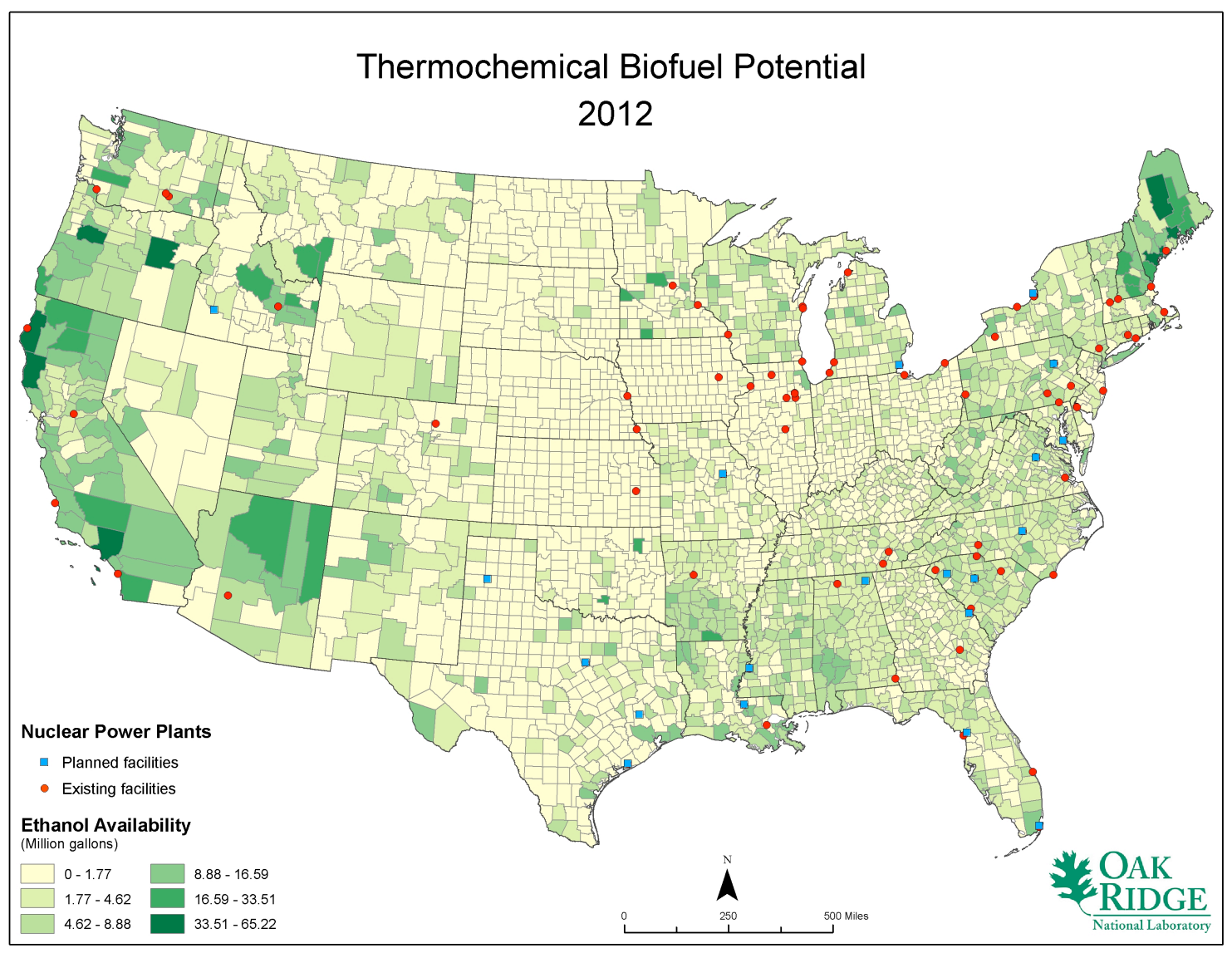

Map generated by Robert Perlack, Oak Ridge National Laboratory.

Fig. 4.2. GIS map of existing and planned nuclear facilities overlaid with estimated ethanol production potential via the thermochemical conversion of biomass feedstocks. Feedstocks included for estimating the thermochemical ethanol potential include forest products residues, urban wood residues and wastes.

\subsubsection{Nuclear power plant siting considerations}

An early site permit is generally required for nuclear plant construction because by statute, the NRC must determine if the site is suitable for construction of a nuclear facility. One of the regulations (10CFR50.34) requires an exclusion boundary to be imposed around the plants, the border of such is determined by the dose to an individual for 2 hours after a severe accident should not exceed 25 Radiation Equivalent Man (rem) unit of dose. Most Light Water Reactors (LWR) have adopted a standard radiation source term that the NRC has approved for use in calculating the exclusion boundary. Using those guidelines, the boundary is generally about 0.5 miles in radius. With recent security upgrades this boundary also acts as a first security barrier. It is possible to reduce this boundary if the designer provides a reduced site-specific source term for calculation of site boundary dose and the NRC 
accepts its use. Therefore, for a smaller inventory and passively safe reactor such as IRIS, it may be possible to reduce this exclusion boundary. However, the current published information about the design assumes the standard at this time. It should be assumed that it would be unlikely that the biochemical refinery could be colocated any closer to the nuclear plant than the exclusion radius boundary.

Transporting the low temperature and low-pressure steam over 0.5 miles from the nuclear turbine building to the refinery will result in some loss in both temperature and pressure. Typically, a line carrying $164^{\circ} \mathrm{C}$ steam will loose heat at the rate of $192 \mathrm{Btu} / \mathrm{hr} / \mathrm{ft}$, when a 12 -inch pipe is used with 3 inch insulation. ${ }^{4.5}$ This amounts to about $0.15 \mathrm{MW}$ energy loss, which can be anywhere from 0.1 to 2 percent, depending on the steam flow rate.

Perhaps more important than power loss is loss in steam pressure over long runs of steam piping and through an intermediate steam heat exchanger. A 1986 study by TVA to examine the use of the Yellow Creek Nuclear Plant to produce industrial steam showed pressure losses of over 50 percent for the range of pressures considered, which are similar to those needed for the ethanol/nuclear system described in Chapters 2 and 3. ${ }^{4.6}$ The report estimates the cost and impact on the electrical output plant efficiency. The results are summarized in Appendix A.

In order to reduce process steam losses, the refinery would likely be located at the exclusion boundary. This will place it in an area called the low population zone. The low population zone boundary is also determined by the regulation 10 CFR Part 50.34 and assumes an individual located at the low population boundary will not receive a dose greater that 25 rem over the entire time the plume passes the individual. Persons living and working in the low population zone are expected to be able to take cover or evacuate the area in the case of an accident at the nuclear plant. This would imply that the refinery would be involved in the emergency planning aspects of the nuclear plant. Since there is expected to be a large number of trucks moving in and out of the refinery, this could present some challenges with regard to emergency planning. Also, safe shutdown activities within the refinery would need to be rapid enough so the operators and workers would not be expected to be exposed to significant radiation dose while shutting down the refinery.

A population center should be located no closer to the nuclear reactor than $11 / 3$ the distance to the low population area boundary. An emergency planning zone extends out to a 5-10 mile radius from the nuclear plant. Neither of these should impact the refinery location or operation except during drills.

\subsubsection{Water requirements}

The nuclear plant is estimated to need $5200 \mathrm{gal} / \mathrm{min}$ of make-up water (lost as waste heat). The thermochemical plant requires 800 gal $/ \mathrm{min}$ make-up water. Although the latter can be supplied with well water, co-location of these plants will likely need access to a river or lake. This may place restrictions on the sites that are available for the construction of the refinery. 
Licensing for a nuclear power plant requires a fire protection system. Usually the water for this system is independent of the cooling system. Most nuclear plants use a stored water tank. It is unlikely that this fire water system could be shared with the refinery. Thus two such systems would be needed for a cogeneration plant.

\subsubsection{Material flow management (feedstocks, fuel, wastes, and products)}

Nuclear power plants generate low-level waste in the form of filters, clothing, gloves etc. In the case of IRIS it is estimated that this amounts to $870 \mathrm{cu} \mathrm{ft} / \mathrm{yr}$. Generally this is accumulated on site and is disposed of in an approved site. States that do not currently have a nuclear power plant may have difficulty disposing of this additional waste at their approved site. If this cannot be done, the waste must be stored onsite. It is unlikely this will have any significant effect on a nearby refinery.

In addition to low-level waste, the nuclear plant currently must store the spent fuel onsite until a national repository is available. The IRIS currently is designed to store one spent fuel core in its spent fuel pool and the rest would require above ground dry storage. This amounts to about 20 casks over the 60 -year life of the reactor. This material will become a legacy waste that may remain even if the reactor is shutdown until it is scheduled for disposal in a national repository. This is unlikely to have any significant impact on a nearby refinery, except for the case where a national repository is unavailable and the waste must be retained onsite following plant decommissioning. The spent fuel would be removed from the site using large spent fuel shipping casks. These are usually transported by rail.

The reactor also has the capacity to store half of a fresh core on site. This generally increases the security while the fuel is onsite, this usually occurs just before refueling the reactor.

The presence of waste, stored fuel and fresh fuel all are included in the setting of the exclusion area boundary and the restricted access site boundary.

It should be noted that both of the ethanol refineries have a life of 20 years, which is one third that of the nuclear power plant.

\subsection{Staffing considerations}

Nuclear plants employ a rather large and skilled staff on a 24/7 basis. In addition, the current plants on the average have about 75 highly trained security personnel on site as well. All staff within the exclusion boundary are required to be trained and have background checks. Access to site would be restricted for those not having clearances and generally such individuals will need to be escorted while on site.

Generally staffing of the refineries require fewer individuals having more typical industrial level clearances as well as far fewer security forces. 


\subsection{Construction and Licensing Considerations for Co-located Biorefineries and Nuclear Power Plants}

Table 4.4 presents a summary of biorefinery and nuclear power plant characteristics and requirements relevant to the construction phase of a plant.

\subsubsection{Construction}

\section{Table 4.4. Biorefinery and nuclear power plant construction and licensing characteristics.}

\begin{tabular}{|l|l|l|l|}
\hline $\begin{array}{c}\text { Construction Phase } \\
\text { (Time to Construct) }\end{array}$ & Nuclear Plant & \multicolumn{1}{|c|}{$\begin{array}{c}\text { Biochemical } \\
\text { Refinery }\end{array}$} & $\begin{array}{c}\text { Thermochemical } \\
\text { Refinery }\end{array}$ \\
\hline A: Site Permit & 3 years & n/a & n/a \\
\hline B: COL license & 3 years & 0 & 0 \\
\hline C: site preparation & 1.5 years & 1 month & 1 month \\
\hline D: Construction & 3 years & 2.5 years & 2.5 years \\
\hline E: Startup testing & 6 months & 1 month & 1 month \\
\hline TOTAL From DECISION & 11 years & $2.5-3$ years & $2.5-3$ years \\
\hline
\end{tabular}

Table 4.4 shows the difference in the construction times associated with the nuclear plant and the biorefineries. As discussed earlier, the site selection process for the nuclear plant is quite rigorous, limiting suitability of locations for these plants. For the biorefineries, the type of feedstock used influences siting. Since thermochemical plants can use a variety of feedstocks including agricultural residues, perennial dedicated biomass feedstocks like switchgrass and poplar, forest product residues, municipal waste, etc, siting of these refineries depends on which feedstock is used by the particular refinery. In general, these refineries will be geographically spreadout as compared to the biochemical refineries. The 50-mile boundary, which is derived from the agricultural feedstock supply costs may change specially for the thermochemical refinery siting, when the feedstock is not an agricultural product.

A difference of 8 or 9 years in construction time may exist between the thermochemical refinery and the nuclear facility as well. There may be existing nuclear plants that could be modified to supply steam required for biorefineries, where the difference in construction will not be a factor. The maps in Figs. 4.1 and 4.2 shows existing and planned nuclear facilities overlaid with the ethanol production potential (estimated for 2012). These maps give an idea of potential synergistic facilities that may be investigated, including the existing or near-term planned nuclear facilities, where the construction time may not be a significant controlling factor.

The commodities needed for construction of a nuclear plant the size of the IRIS are significant (possibly 50,000 $\mathrm{m}^{3}$ of concrete and 13,000 tones of steel). The availability of large amounts of these commodities (particularly, the concrete) may be a problem for some sites in rural settings. In addition, the IRIS plant and several 
other GAR type reactors use very large pressure vessels, which maybe difficult to move to the site except by barge. Thus, a navigable waterway probably is needed for the nuclear plant installation, while most of the refinery components are likely to be delivered to the site using rail or motor transport.

\subsubsection{Licensing}

A second "scaling issue" one must address is related to the time required to design, build, license, and commission nuclear power plants and biorefineries - or rather the substantial difference in these times (e.g., the "time gap"). Biorefineries are lightly regulated compared to nuclear power plants. Construction and permitting/licensing times for biorefineries are much shorter than that for nuclear power plants (3 years vs. 7-10 years). This time gap creates a number of challenges for those seeking to construct a practical enterprise strategy.

Because the nuclear plant is regulated from its inception, each step of the construction process is covered by federal regulations. The IRIS reactor uses innovative techniques in its design for the express purpose of reducing the onsite construction time and cost. It uses significant fewer commodities during construction and employs offsite factory construction to the extent possible. As a result, it has reduced the projected on-site construction time to 3 years. This is close to the construction time estimated for the biochemical ethanol refinery. However, the regulatory process that is required prior to initiating on-site construction for a nuclear plant takes considerable time and requires a significant financial commitment on the part of the applicant. The preferred method in the NRC regulations, and one that results in the least financial risk (due to regulatory delays) is to move through the regulatory process in a sequential manner, starting with a site permit, followed by the COL, at which point the applicant would begin site preparation, followed by actual construction and then startup testing. The construction is regulated and requires several NRC reviews as it progresses, as does the startup testing. For this study, it has been assumed that the nuclear plant design would already be certified by the NRC prior to it being considered for power source for a refinery, so this time is not included in the construction time estimate. It is possible that the applicant can combine the site permit process with the COL process, and in the case of the current planned Generation 3+ reactors, several applicants are using that approach to reduce the pre-construction regulatory process time. However, for all the plants that are using this parallel approach, the site has been pre-qualified because it has an existing nuclear plant on the site, or the site was intended to be used as a reactor site and the process simply needs to be upgraded to reflect the characteristics of the new reactor that is being planned. For the ethanol refinery, the site will likely be dictated by the location of the feedstock for the refinery and therefore, the site would most likely not be characterized for the purpose of nuclear plant construction until after is selected. Thus, there would be a high risk for the applicant to pursue a parallel path, since the site may not be qualified for construction of nuclear plant. With a parallel approach, this may not be discovered until the licensing process is well underway, and the time and funds 
would already have been spent. The COL process is anticipated to be shorter once a certified design moves through the regulatory process one time. It is estimated that this could be reduced from 3 to 2 years.

This would reduce the estimated 6 years needed for pre-construction licensing activities to 5 years if the nuclear plant design has already received a COL for use at another site. Any further reduction may introduce regulatory uncertainty into the process, which could have a significant financial penalty for the applicant. It should be noted that there is no guaranteed result associated with nuclear plant licensing, and the process is open to public intervention at several stages in the process.

Thus, a difference of 8 or 9 years in construction time may exist for the two adjoining facilities. This raises a number of issues related to the business model for such a synergistic nuclear/ethanol refinery for construction of new plants. There may be existing nuclear plants that could be modified to supply steam required for biorefineries, where the difference in construction will not be a factor. However, even modification of these plants will require a regulatory review and possible public comment, or a revision to the existing site Environmental Impact Statement (EIS).

\subsection{Plant / Enterprise Economics}

A preliminary economic evaluation demonstrates that the cost of producing steam needed for the thermochemical plant should not exceed the revenue equivalent of 28.5 percent of the product, resulting from the plant (ethanol + mixed alcohols), because this represents a loss of product for generating steam and electricity. This is equivalent to $\$ 9.12 \mathrm{M} / \mathrm{yr}$ (28.5 percent of total revenue of $\$ 32 \mathrm{M}$ ). Thus, a preliminary assessment indicates that use of nuclear steam would be justified, if the steam $(\sim 106 \mathrm{MW})$ can be supplied for a price of $\$ 9.12 \mathrm{M} / \mathrm{yr}$. The distribution of capital, operating, and feed material costs for each of the three plants are shown in Fig. 4.3. A more detailed economic analysis is required to determine the feasibility and practicality of this approach. However, the integration of nuclear cogeneration plants and biochemical refineries essentially depends upon a market for the lignin byproduct. 


\section{Biochem Plant, Costs in Millions of $\$$}

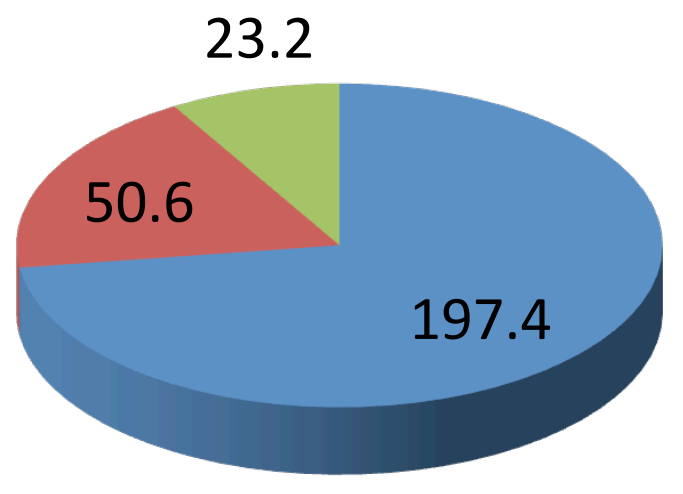

Capital Investment

- Feedstock

Operating Costs

\section{Thermochem Plant, Costs in Millions of $\$$}

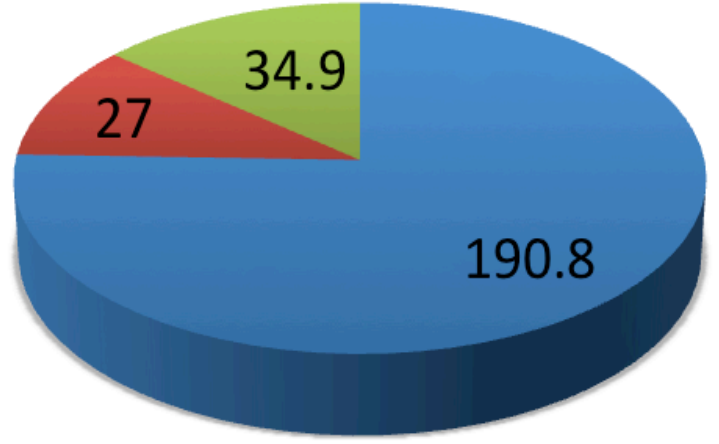

Capital Investment

Feedstock

Operating Costs 


\section{Nuclear Power Plant Costs Estimate}

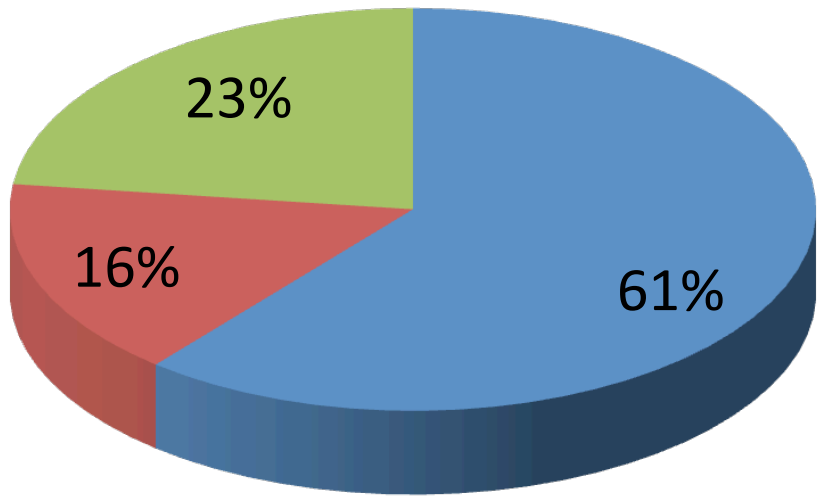

Capital

Fuel

O\&M (incl. D\&D fund)

Fig. 4.3. Pie charts showing capital, operating and feed material costs for the biochemical, thermochemical, and nuclear plants. 


\section{Chapter 4 References}

4.1. F. Putignano and S. Boarin, "Cogeneration Options for IRIS," Politechnico di Milano - LEAP, 19th IRIS Team Meeting, Georgia Institute of Technology, Atlanta, GA, May 2008.

4.2. C. W. Forsberg, "Sustainability by combining nuclear, fossil, and renewable energy sources," 1-9 in Progress in Energy xxx, Elsevier Publishing, 6277 Sea Harbor Dr., Orlando, FL, 2008.

4.3. J. F. Kadla, S. Kubo, A. R. Venditti, R. D. Gilbert, A. L. Compere, and W. Griffith, "Lignin-based carbon fibers for composite fiber applications," Carbon 40, 2913-2920 (2002).

4.4. J. H. Lora, W. G. Glasser, "Recent industrial applications of lignin: A sustainable alternative to nonrenewable materials," Journal of Polymers and the Environment 10, 39-48 (2002).

4.5. Web software for heat loss calculations: 3E plus V4.0, http://www.pipeinsulation.org/.

4.6 Yellow Creek Nuclear Plant Preliminary Steam Tap Feasibility Study, TVA report (1986). 
Blank page 


\section{Thinking Outside The Box: An Integrated Nuclear - Biomass Energy Enterprise}

\subsection{Introduction}

As this report illustrates, the idea of replacing the energy required by, and currently produced on-site in, biorefineries with steam from nuclear power plants entails a number of practical challenges ranging from matters of scale to matters of technology, to issues related to the business model and financial structures required for economical viability and competitiveness.

However, if one considers the question of how the entire nuclear-biofuels enterprise might be optimized in an "energy-rich" environment, a different perspective emerges. The challenge is to avoid sub-optimization of the problem.

\subsection{An Integrated Nuclear - Biofuels Energy Enterprise Model}

What if all of the energy produced by a nuclear power plant was available to "fuel" a biofuels enterprise? The following uses might be considered:

- Enhancing biofuels feedstock production and/or reducing the cost of feedstock transportation to the biorefinery;

- "Powering" the biorefinery (with existing or modified chemical process flowsheets); and

- "Powering" industrial plants that make use of biorefinery byproduct and waste streams liberated because they are no longer consumed in the biorefinery's combustor/boiler.

Figure 5.1 is a simple depiction of a "Nuclear - Biofuels Energy Enterprise" based on these functionalities and inter-relationships.

This model assumes the co-location of

- a nuclear cogeneration power plant, scaled for the enterprise

- a biomass farm or plantation that takes advantage of the "waste heat" from the nuclear plant to promote ultra-high-yield biomass crop growth, and more efficient harvesting, packaging, and transportation of the biomass to the biorefinery

- a biorefinery that is optimized in size and chemistry to utilize the waste heat and electricity products of the nuclear power plant, and 
- industrial (manufacturing) facilities that utilize the byproduct and waste streams from the biorefinery to produce goods and services of value to society.

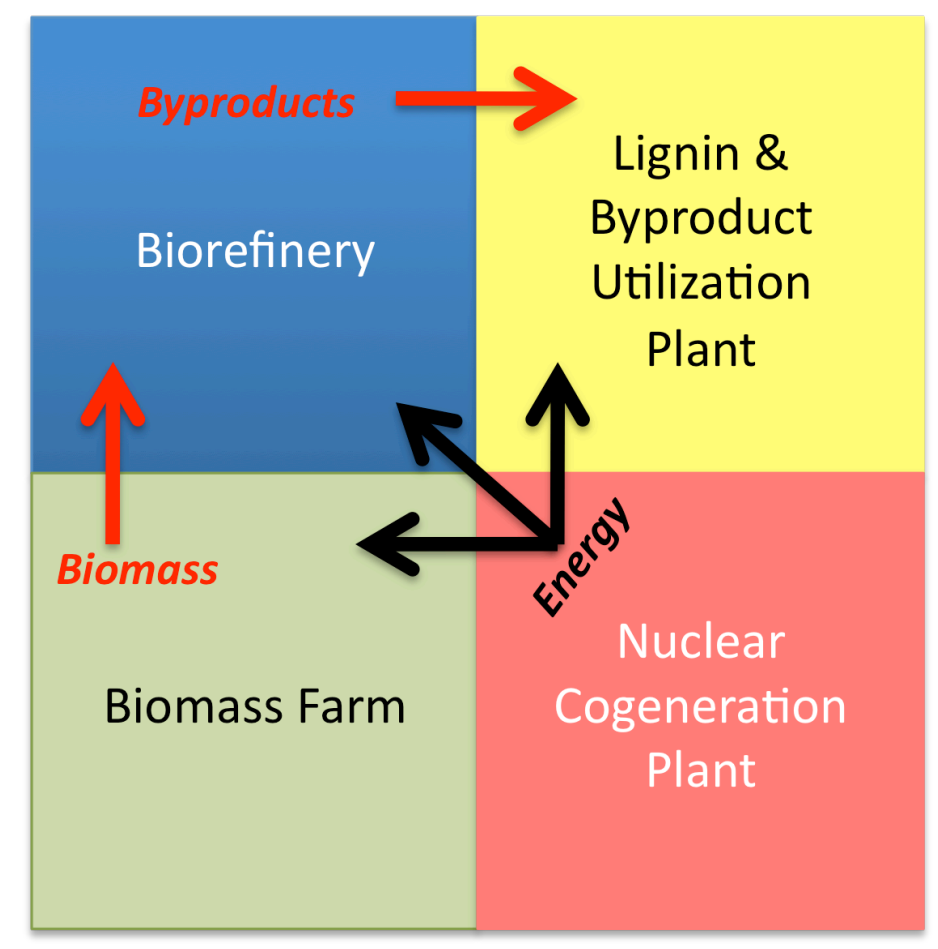

Fig. 5.1. A Co-located Nuclear - Biomass Energy Enterprise

The enterprise model symbolized in Fig. 5.1 is predicated on development of practical answers to a number of questions outlined below.

\subsubsection{Utilizing the Biorefinery Byproducts and Waste Streams}

- What are the potential uses for the lignin and the other byproduct / waste streams from biochemical and thermochemical plants?

Lignin is the largest byproduct resulting from a biorefinery, if it is not used as a fuel for energy production within the biorefinery. Conversion of lignin to value-added products has been researched for several years. Some of the products that have been investigated include: (a) composite polymers, with applications including automotive brakes, wood panel products, biodispersants, polyurethane foams, and epoxy resins for printed circuit boards, 5.1, 5.2 (b) carbon fibers, with applications such as automotive parts, etc., ${ }^{5.3}$ and (c) liquid fuel additives in the gasoline to diesel boiling range. ${ }^{5.4}$ 


\subsubsection{Intense (Ultra-High-Yield) Biomass Farming}

- What specific crops are candidates for intense farming if thermal energy were abundant (e.g. cane, bamboo, cattails, other marsh plants, algae)?

Geothermal agriculture may be possible utilizing hot water stream resulting from the nuclear reactor-coupled turbine (100 percent of which is a waste heat, released into the environment). This is typically at $100^{\circ} \mathrm{C}$ and $1 \mathrm{~atm}$. The hot water may be mixed with irrigation water to elevate the temperature of the soil/water to the optimum required for the crop/plant. This may allow growth of energy crops/plants in colder climates and increase the yield of biomass via an increase in the growing season. Several tropical biomass crops may be candidates for geothermal agriculture. Sugar cane and possibly energy cane can potentially be grown at their optimum temperature (between $\left.30-38^{\circ} \mathrm{C}\right)^{5.5}$ in climates with moderate temperatures to increase their yield.

- What biomass sources are candidates for production and/or "harvesting" in an energy-rich environment?

- Are there other non-vegetative biomass sources that might become attractive if thermal energy becomes available for pre-processing and/or extraction?

\subsubsection{An Optimized Biorefinery}

- What optimized or alternative chemical processes are candidates for existing Rankine cycle waste heat streams and/or alternative high-yield biomass crops that could be grown if thermal energy were abundant?

\subsubsection{The Nuclear Cogeneration Plant}

- If it produces electricity - how much?

- Does the nuclear cogeneration plant generate electricity to meet its own housekeeping loads, or those of the entire enterprise?

\subsubsection{Energy Enterprise Siting Issues}

- Siting considerations for an integrated nuclear-biomass energy enterprise?

- Acreage?

- Water?

- Civil Infrastructure?

- Climate?

- Latitudes / Longitude?

- Intra-site biomass transportation issues

- Potential for upgrading the existing biofuels using the waste heat? Is there a way to produce hydrogen using waste heat - enabling upgrade of pyrolysis oils, lignin and other products/fuels to more energy dense fuels? 


\subsubsection{Enterprise economics}

- How does one analyze this enterprise scenario from the cost and economic perspective?

- What is the standard of comparison? 


\section{Chapter 5 References}

5.1. J. H. Lora and W. G. Glasser, "Recent industrial applications of lignin: A sustainable alternative to nonrenewable materials," Journal of Polymers and the Environment 10(1-2), 39-48 (2002).

5.2. J. D. Megiatto, F. B. Oliveira, D. S. Rosa, C. Gardrat, A. Castellan, E. Frollini, "Renewable resources as reinforcement of polymeric matrices: Composites based on phenolic thermosets and chemically modified sisal fibers," Macromolecular Bioscience 7(9-10), 1121-1131 (2007).

5.3. J. F. Kadla, S. Kubo, R. A. Venditt, R. D. Gilbert, A. L. Compare, and W. Griffith, "Lignin-based carbon fibers for composite fiber applications," Carbon 40(15), 2913-2920 (2002).

5.4. J. Shabtai, E. Zmierczak, E. Chornet, and D. Johnson, "Conversion of lignin to production of high-octane additives," ACS Div. Fuel Chem, Preprint 44, 267-272 (1999).

5.5. T. Takayoshi, M. Makoto, K. Makoto, and N. Hiroshi, "Effect of temperature and fertilizer application on sugar accumulation in relation to invertase activity in sugarcane," Japanese Journal of Tropical Agriculture 43(10), 1825 (1999). 
Blank page 


\section{Summary and Recommendations}

\subsection{Observations}

This report presents the results of a preliminary study conducted to identify major issues associated with integration of nuclear cogeneration power plants and biorefineries. Due to time and resource constraints, the study was limited to an examination of plant-to-plant and technology integration issues, and focused on biofuel refinery and nuclear power plant technologies and designs expected to be or that could be made available within the 2020 timeframe. One can conclude based on the observations below, that at a high level it appears that the energy interface is achievable especially for the biorefinery. However, there are other issues that have not been discussed in the recent publications dealing with the synergism between nuclear plants and ethanol production facilities that may make this a less attractive scenario. These have to do with the scaling mentioned previously, the regulations imposed on the nuclear plant, economics of modifying existing plant designs (both refinery and nuclear plants), and the fact that the ethanol refinery designs are highly intergrated to make efficient use of feedstock as well as waste products. A much more detailed systems study is needed to determine if these potential impediments can be eliminated.

As summarized in Chapter 4, four major observations are evident:

Observation 1: The steam conditions in current and near-term Rankine-cycle nuclear power plants appear compatible with the steam required to support fermentation processes, provided the thermal energy can be transported to the biorefinery without unacceptable reductions in quality. However, current Rankine cycle nuclear power plants cannot directly meet some of the heat loads in thermochemical refineries, unless the thermochemical refineries retain their ability to super-heat the steam using excess heat from the thermochemical process.

Observation 2: (Scale Issue \#1) There is a large mismatch in size (and energy demand) between the largest ethanol refineries currently on the planning board, and the smallest nuclear power plants (energy supply) currently under development that are capable of meeting the steam conditions required by the ethanol refineries. Power needs for the refinery are around 100MWt while the nuclear plant produces $1000 \mathrm{MWt}$. Integration of the two technologies might be possible by shrinking this size gap by designing larger ethanol refineries and small nuclear power plants, or developing energy bridging technologies that would allow the biorefinery to act as a small parasitic load on traditional, large ( $>1 \mathrm{GWe}$ ) nuclear power plants.

Observation 3: (Scale Issue \#2) There is currently a significant mismatch between the time required to design, construct, and permit/license a biorefinery, 3 years, and a nuclear power plant, ( 3 years vs. 9-11 years, respectively). This time differential 
raises significant challenges with respect to development of viable cash flow / revenue streams, and enterprise business models.

Observation 4: Biorefineries are highly integrated designs in which the combustor is an integral component of the plant's byproduct and waste management strategy. Elimination of the combustor would likely force numerous changes in the overall biorefinery plant design and waste management strategies.

Observation 5: It is possible that a more comprehensive formulation of the "nuclear-biofuels energy enterprise" model that embraces maximum utilization of the energy available from a nuclear power plant in biomass production/harvesting, biofuels synthesis, and in biorefinery byproduct utilization might provide a promising area for exploration.

\subsection{Additional Insights and Issues Needing Further Study}

In addition to these major observations several other issues were identified in the study, and these require further analysis.

1. The distance between the nuclear power plant and the ethanol refinery was estimated to be 0.5 miles, which is the typical exclusion boundary distance prescribed by regulations. Based on the TVA study outlined in Appendix A, the pressure drops associated with long runs of pipe and steam-to-steam heat exchangers are significant. The estimated capital costs of a system with long runs of insulated steam piping along with intermediate steam-to-steam heat exchangers will be a major cost factor in the economics study. The high costs of modifying existing nuclear plants cited in the TVA study may impact any decisions to use existing nuclear power plants as a possible source of steam even if they reside in the vicinity of a proposed ethanol refinery.

2. The regulatory requirements for siting a nuclear power plant (seismic, hydrogeology, flooding, makeup water availability etc.) may limit the number of available nuclear/ethanol sites available for consideration.

3. The need to use barges to transport some of the nuclear components and the large amount of structural commodities needed for constructions (especially steel and concrete) may be a factor in siting plants in rural locations. However, some proposed conceptual designs eliminate the need for barge transport.

4. Security and emergency response issues need further exploration with regard to co-location of the two facilities. 


\subsection{Recommendations}

As discussed above, fermentation processes appear to be a better direct match for the thermal energy sources available from present and near-term Rankine steam cycle nuclear power plants than does the thermochemical process. However, the difference in scale between the size of the biorefinery and nuclear power plant is a significant challenge. Given this reality, the following recommendations are presented:

Recommendation 1: A detailed evaluation to identify and assess promising "thermal energy bridge technologies" that might facilitate utilization by the fermentation refinery of thermal energy from water-cooled Rankine power plants (independent of size). This analysis would highlight approaches and technologies that might facilitate operating the biorefinery as a relatively small parasitic load on the power conversion or thermal waste heat stream of the nuclear power plant. Such an approach would not necessitate focusing on nuclear power plants of a particular size. A systematic survey of present and near-term cogeneration and waste-heat management technologies would be a foundation of this analysis.

Recommendation 2: A systems-level plant energy flow model of an integrated fermentation refinery and a nuclear power plant water Rankine power conversion / waste heat management to better understanding energy flow and management issues within the integrated nuclear-biofuels plant. This effort should coincide with the evaluation described in Recommendation 1 . The analysis would focus on the issue of combustor elimination and waste energy recovery in the biorefinery, as well as options for optimizing the overall nuclear power plant power conversion and waste heat management strategy to accommodate the load from the biorefinery.

Recommendation 3: An evaluation to determine if there are alternative biomass crops and/or biomass sources and alternative biorefinery chemistries that could become available if the waste heat from nuclear power plants were available to "fuel" crop production or biomass recovery from sources such as municipal and industry waste streams.

Recommendation 4: Accelerated research to identify value-added uses for biorefinery byproducts (e.g. lignin). Possible alternative uses for these byproducts may emerge that would render them too valuable to "burn."

Recommendation 5: A workshop, bringing together the biofuels community, the nuclear energy community, and relevant policy makers, regulators, and investors, to explore a broader range of policy, regulatory, logistical, and financial issues associated with co-location and integration of biorefineries and nuclear cogeneration power plants. 
Recommendation 6: An augmented technical analysis, expanding on this study, with an economic analysis that would complete the assessment and lay the grounds for a business plan.

Recommendation 7: In-depth regulatory analysis to identify existing regulatory impediments to implementing the concept of an integrated nuclear-powered ethanol refinery, and to identify a strategy for a licensing plan for a small nuclear facility that may allow reconsiderations of some or all of these impediments.

Recommendation 8: A short study conducted in conjunction with the designer of NUSCALE to determine if outlet temperature can be increased without compromising the safety claims made by the designer. As mentioned in Chapter 3 of this report, a design for a smaller (150 MWt) nuclear reactor, NUSCALE, (which is based on the MASLWR design) is being pursued and interactions with the NRC have begun. However, its steam temperature is currently too low to meet the needs of the existing ethanol refinery designs.

Recommendation 9: Further study to determine the effect on the thermochemical plant if steam from the nuclear plant is used but augmented in quality by superheating using the by-product streams from the thermochemical process. 


\section{Appendix A: \\ Summary of the 1986 TVA Report - "Yellow Creek Nuclear Plant Preliminary Steam Tap Feasibility Study"}

\section{A.1 Cases Examined}

A study was done in 1986 by the Tennessee Valley Authority (TVA) that examined the technical feasibility and capital cost of extracting energy from the Yellow Creek Nuclear Power Plant to provide steam to an offsite location for industrial use.

The report examined the best potential locations in the nuclear plant to use as extraction points. The major features of the extraction system are 1) the extraction supply lines from the power plant, 2) an industrial process steam evaporator (IPSE) system, and 3) the industrial interface piping system.

Several extraction points were considered and three were deemed the most practicable. These were: 1) extracting steam from the main steam system downstream of the main steam isolation valves [Figs. 1-2]; 2) extracting the steam from the high-pressure turbine via the existing first stage extraction piping [Figs. 23]; and 3) extracting steam from the cold reheat portion of the steam cycle [Fig. 3].

For all cases the steam piping in the turbine building was run through the main steam system tunnel where it exited the Turbine Building. The piping then ran above ground to the ISPE, this allowed for thermal expansion and reduced interference with existing plant features. Piping restraints are required in the vicinity of the nuclear power plant to preclude steam pipe rupture and pipe whip damage. The extraction condensate line was routed along side the steam piping on common supports, and it terminated at the main condenser.

The ISPE isolates the nuclear plant steam from the industrial steam to preclude any potential radioactive contamination offsite. The ISPE was located in a separate building midway between the reactor and industrial plant. The ISPE contains feed water heater, evaporators, de-aerators, booster pumps, condensate cleanup systems and I\&C system. Electric power, potable water and fire protection water are shared with the power plant. This building was $58 \mathrm{ft}$ tall covering an area ranging from 9,390 square feet to 10,280 square feet depending on the size of equipment, which in turn is based on the varying steam conditions coming from the three potential extraction points.

The industrial process steam piping is also located above ground to permit thermal expansion. The industrial interface was not part of the study. The park was assumed to be located on the site boundary. All the steam piping was insulated. 


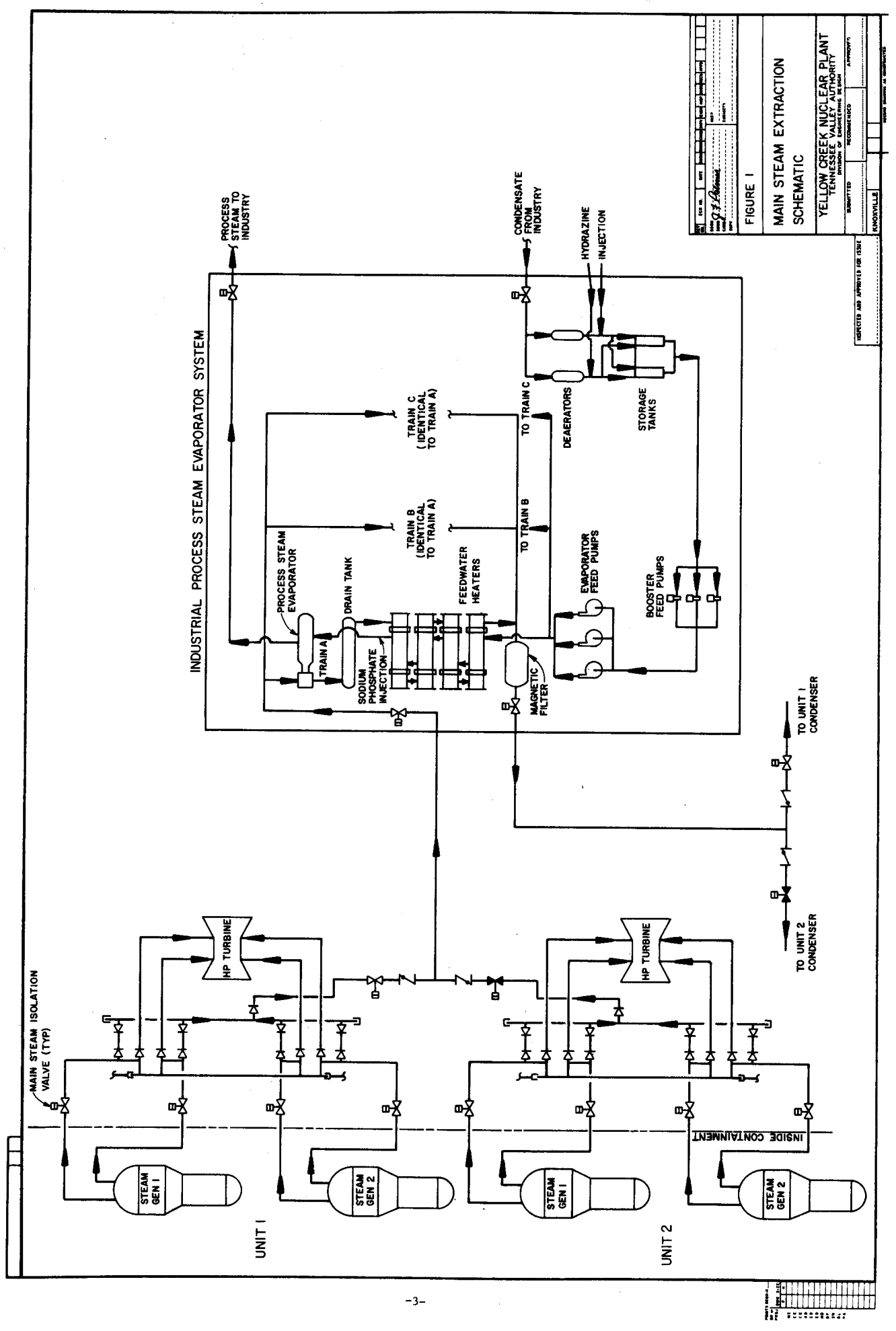

Fig. A.1. Main steam extraction schematic. 


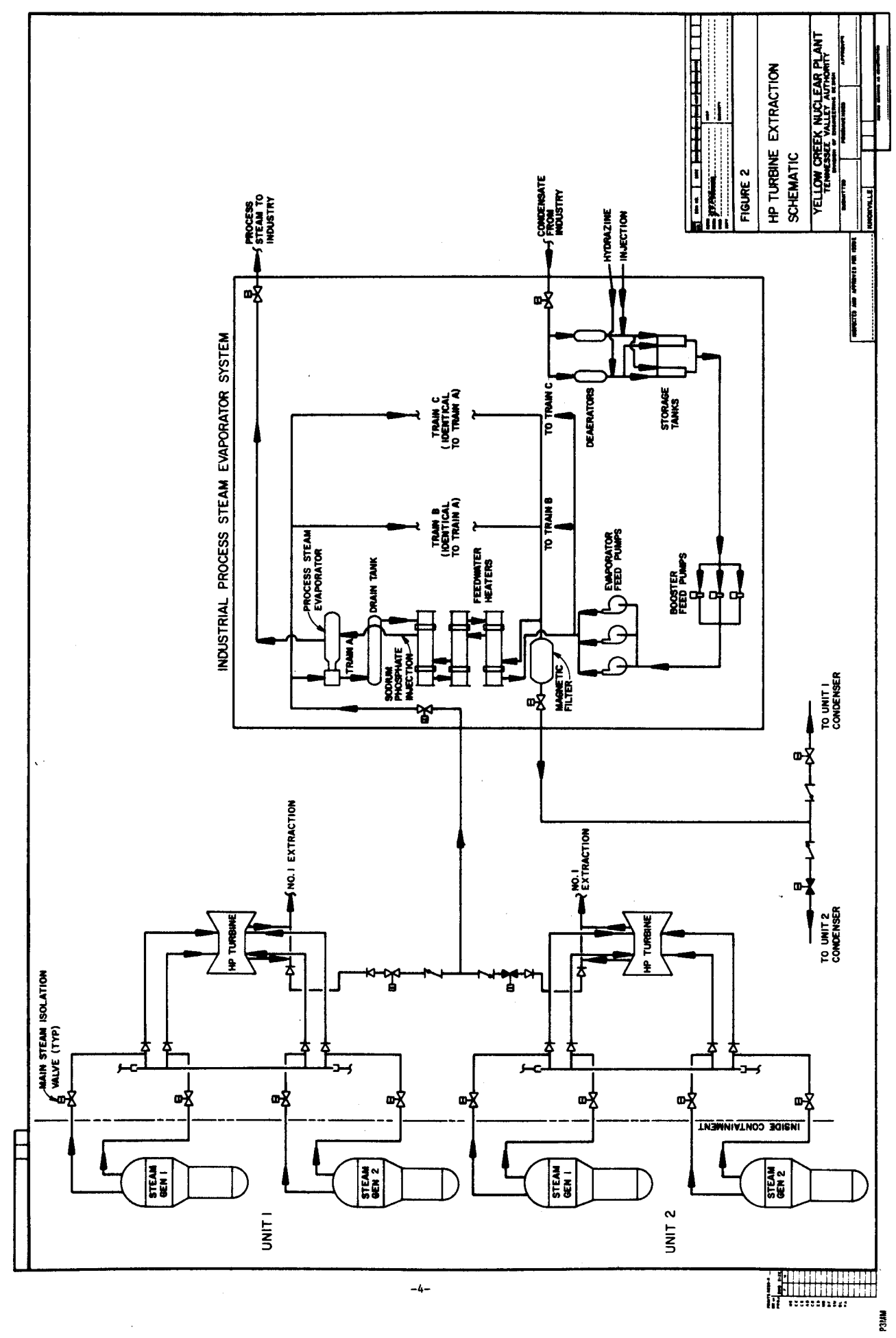

Fig. A.2. High-pressure turbine extraction point schematic. 


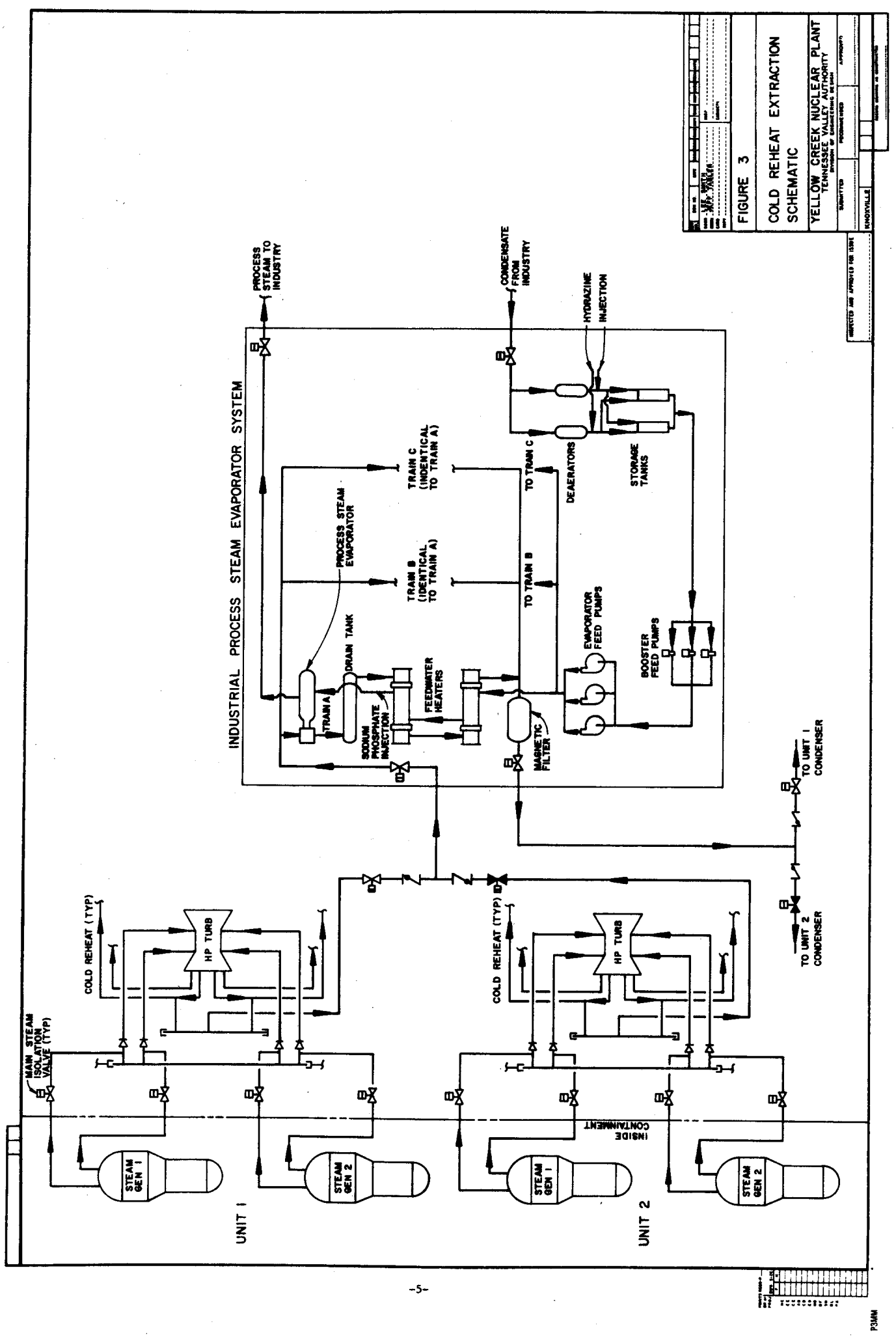

Fig. A.3. Cold reheat extraction point schematic. 


\section{A.2 Results}

\section{Table A.1. Comparison of process heat conditions and efficiency impacts for the three extraction points.}

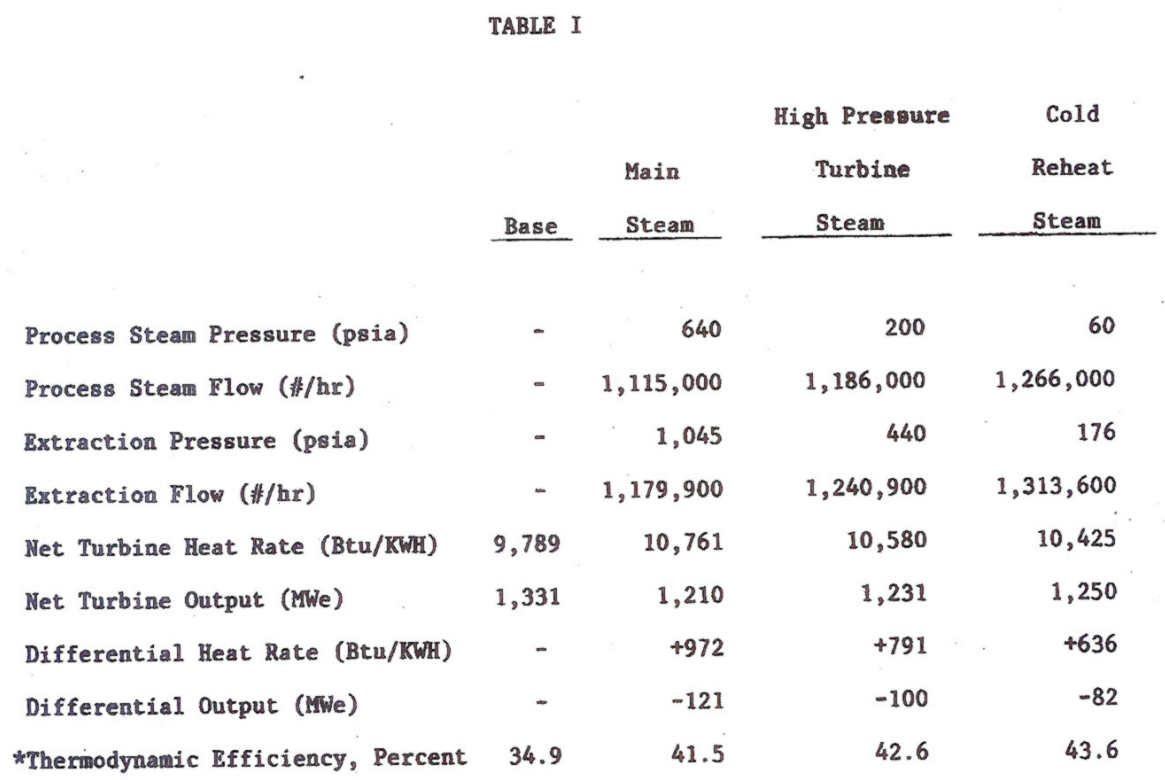

*Efficiency on a per-unit basis.

This table does not illustrate the further reduction of steam pressure at the industrial site boundary to 578 psia (45 percent reduction) for case $1 ; 174$ psia (61 percent reduction) for case 2 ; and 52 psia (71 percent reduction) for case 3 .

Table 2 summarizes the capital cost in 1986 dollars for each option. The cost variance between the high-pressure and lower pressure options is due primarily to the size of the piping needed to maintain a reasonable steam pressure at the industrial boundary (at lease 50 psia for case 3). The costs adjusted to 2008 dollars are $\$ 136,747,000$ for case $1 ; \$ 142,032,000$ for case 2 ; and $\$ 177,408,000$ for case 3 . 


\section{Table A.2. Cost Estimate for installation of steam extraction system for use by industry as process heat.}

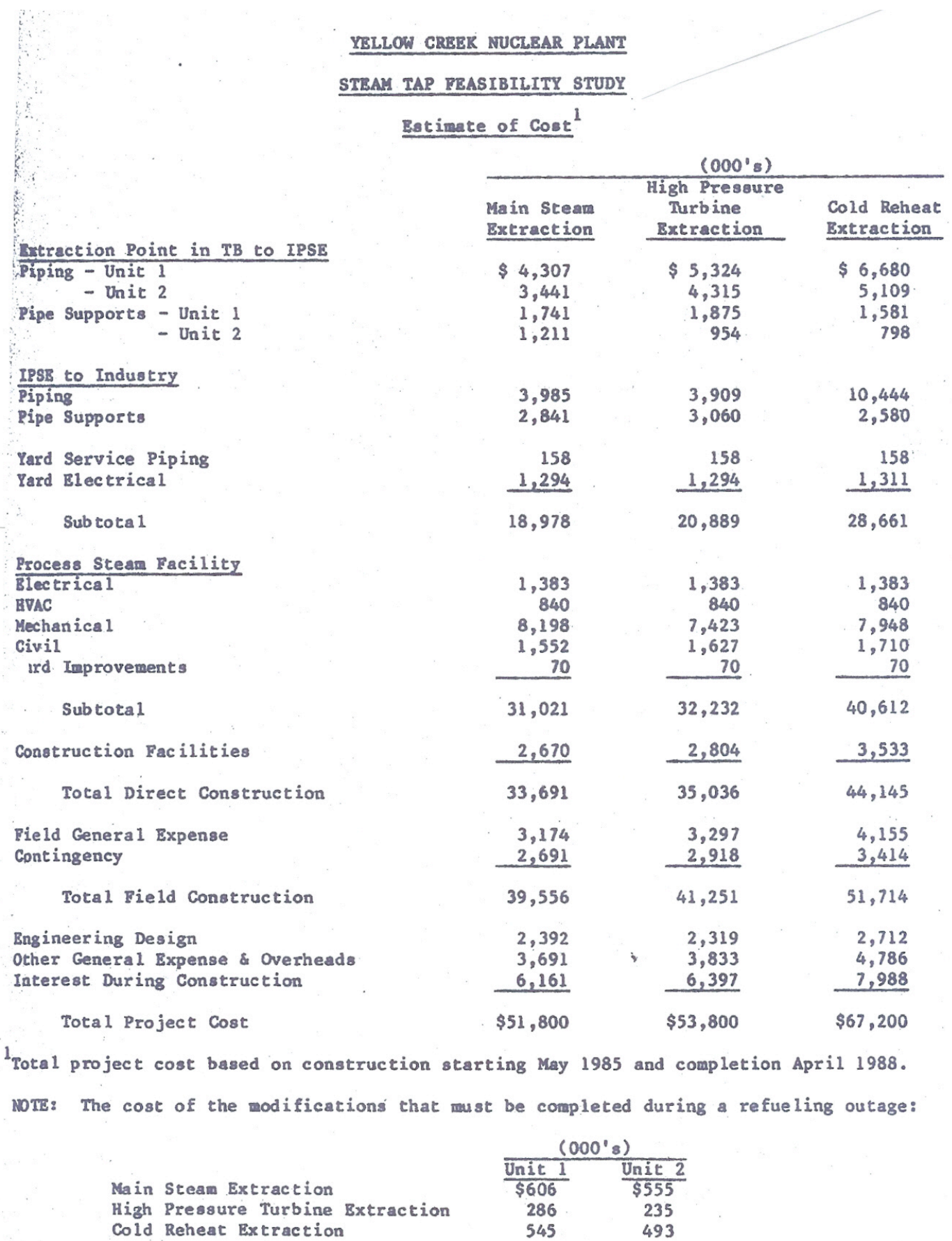




\section{A.3 Conclusions}

The study concluded that feasibility depended not only on the technical considerations and capital cost, but also on the marketability of specific steam pressure, the value of lost electrical capacity, cost of maintenance, and costs of alternative steam generation processes. 
Appendix A: Summary of the 1986 TVA Report - "Yellow Creek Nuclear Plant Preliminary Steam Tap Feasibility Study"

\section{Appendix A References}

A.1 Yellow Creek Nuclear Plant Preliminary Steam Tap Feasibility Study, TVA report (1986). 
ORNL/TM-2008/102

ORNL/GNEP/LTR-2008-047

\section{Internal}

1. C. A. Blue

2. A. P. Borole

3. D. C. Christensen

4. B. H. Davison

5. G. F. Flanagan

6. J. C. Gehin

7. R. L. Graham

8. S. R. Greene

9. D. T. Ingersoll
10. M. Keller

11. T. J. King

12. G. T. Mays

13. J. R. Mielenz

14. J. E. Rushton

15. D. L. Williams

16. K. A. Williams

\section{External}

17. A. Aden, National Renewable Energy Laboratory, 1617 Cole Blvd., Golden, CO 80401-3393

18. J. A. Beaudry-Losique, EE-20/Forrestal Building, U.S. Department of Energy, 1000 Independence Ave., S.W., Washington, DC 20585

19. R. L. Black, NE-3/Germantown Building, U.S. Department of Energy, 1000 Independence Ave., S.W., Washington, DC 20585-1290

20. C. W. Forsberg, Massachusetts Institute of Technology, 77 Massachusetts Ave., Cambridge, MA 02139

21. T. D. Foust, National Renewable Energy Laboratory, 1617 Cole Blvd., Golden, CO 80401-3393

22. Z. U. Haq, EE-2E/Forrestal Building, U.S. Department of Energy, 1000 Independence Ave., S.W., Washington, DC 20585

23. R. A. Hawsey, National Renewable Energy Laboratory, 1617 Cole Blvd., Golden, CO 80401-3393

24. V. A. Lightner, EE-2E/Forrestal Building, U.S. Department of Energy, 1000 Independence Ave., S.W., Washington, DC 20585

25. T. P. Miller, NE-31/Germantown Building, U.S. Department of Energy, 1000 Independence Ave., S.W., Washington, DC 20585-1290

26. D. M. Miotla, NE-3/Germantown Building, U.S. Department of Energy, 1000 Independence Ave., S.W., Washington, DC 20585-1290

27. R. R. Price, NE-54/Germantown Building, U.S. Department of Energy, 1000 Independence Ave., S.W., Washington, DC 20585-1290

28. V. A. S. Reed, EE-2E/Forrestal Building, U.S. Department of Energy, 1000 Independence Ave., S.W., Washington, DC 20585

29. S. Rosenbloom, HS-21/Germantown Building, U.S. Department of Energy, 1000 Independence Ave., S.W., Washington, DC 20585-1290

30. R. F. Smith-Kevern, NE-31/Germantown Building, U.S. Department of Energy, 1000 Independence Ave., S.W., Washington, DC 20585-1290

31. B. J. Williams, NE-5/Germantown Building, U.S. Department of Energy, 1000 Independence Ave., S.W., Washington, DC 20585-1290 